\title{
فعالية برنامج إرشادي قائم على العلاج بالمعني لخفض الخض الاكتئاب الناتج عن تأخر سن الزواج لادى المعلمات
}

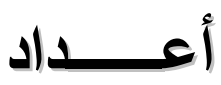

د. فاطمة محمد الزاهر عبدالله

مدرس الصحة النفسية

كلية التريبة - جامعة ب أكتوير
د. نور الاين طه السنبارى

دكتوراه الإرشاد النفسي

كلية الدراسات العليا للتربية - جامعة القاهرة

مجلة الدراسات التربوية والانسانية ـ كلية التربية ـ جامعة دمنهور

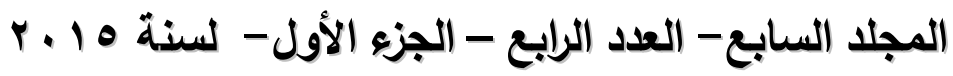


فعالية برنامج إرشادى قائم على العلاج بالمغنى لخفض الاكتئاب الناتج عن تأخر سن الزواج لدى المعلمات

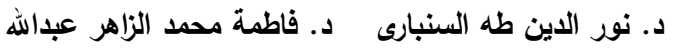




\section{فعالية برنامـج إرشادى قائم على العلاج بالمعنى لخفض الاكتئاب الناتج عن تأخير سن الزواج لاى المعلمات}

د. نور الدين طه السنبارى

د. فاطمة محمد الزاهر

يعد الزواج أسمى وأعظم العلاقات الإنسانية التي تجمع بين الرجل والمرأة، فقد الزاهر

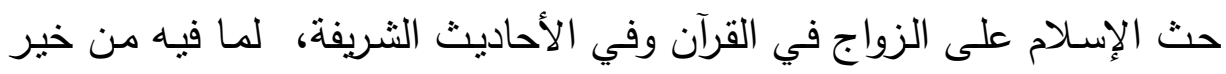

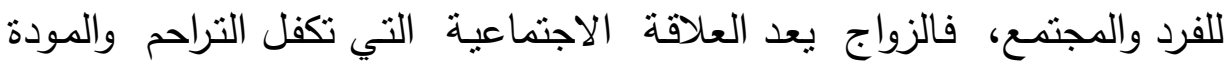

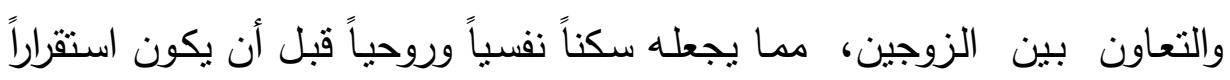

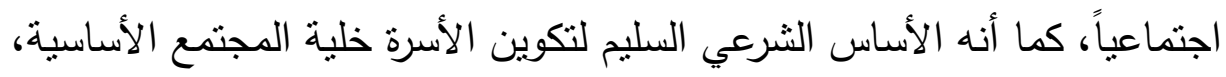

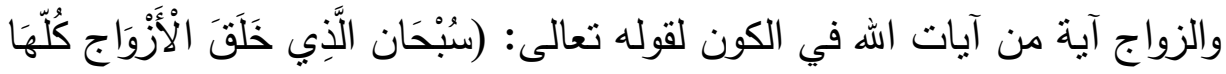

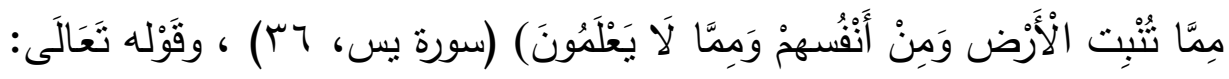

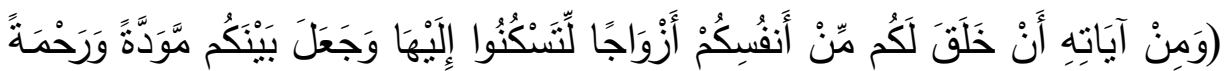

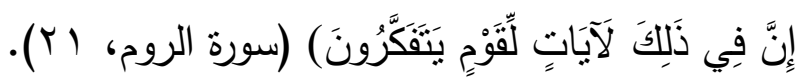

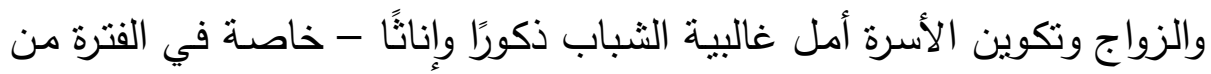

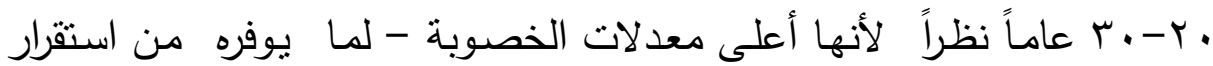

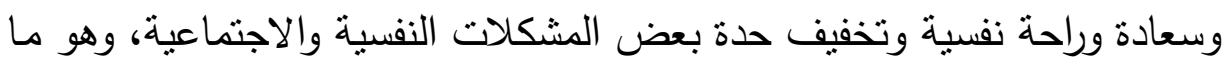

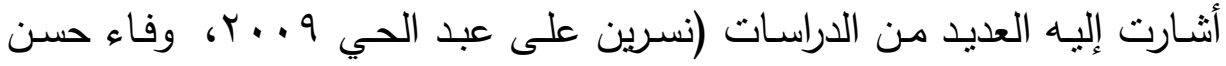

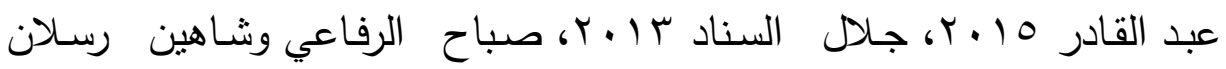
.$(r \cdot V$

وقد أثثتت الدراسات أن معظم الفتيات المتأخرات زواجياً يلجئن في بعض الأحيان لمواجهة هذه الضغوط إلى الاستراتيجيات غير الفعالة، أي التي تعتمد

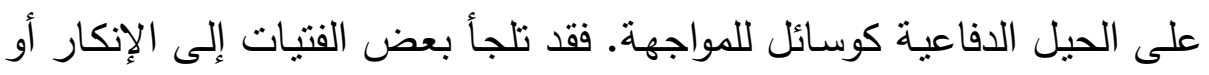

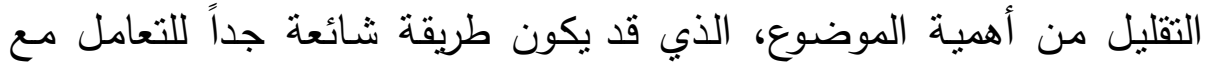
الأحداث المأساوية التي قد تخفف من المأسـاة بطريقة ذاتيـة، كأن تحاول الفتاة I.V 
تخفيف حدة القلق والتوتر التي تتتابها من خلال الابتسامة أو الضحك، أو

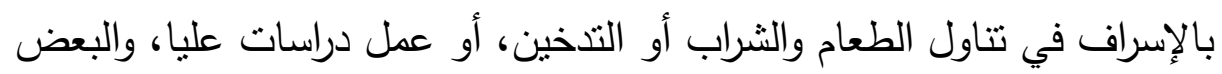

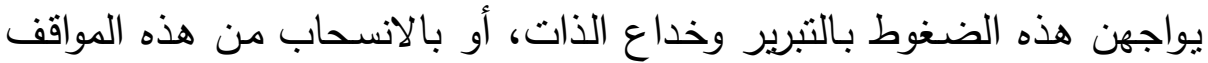

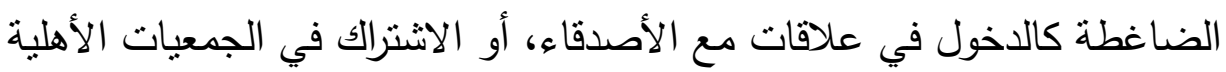

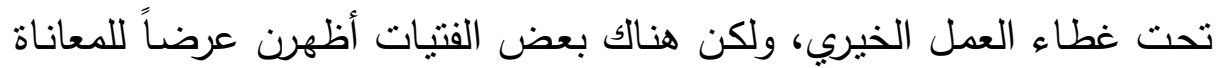

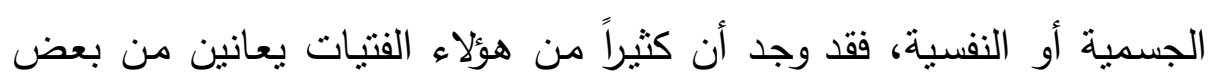

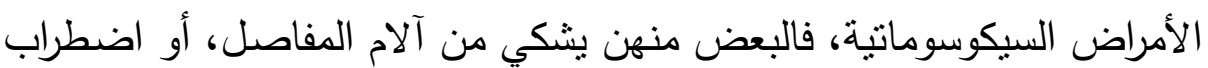

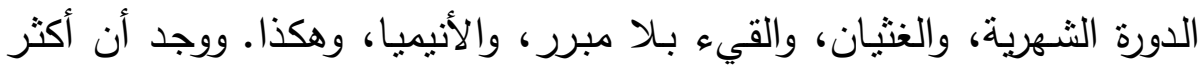

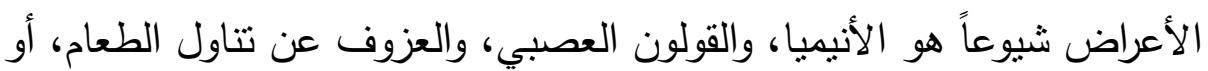
البدانة في بعض الأحيان؛ والذى قد ينعكس بدوره على درجة التوافق النفسي لهن

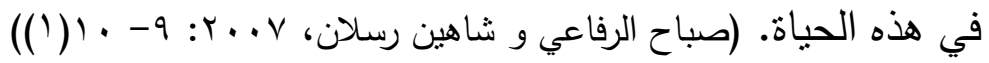

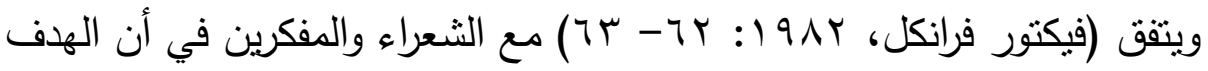

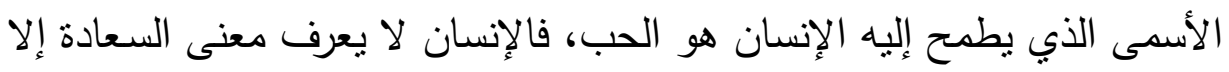

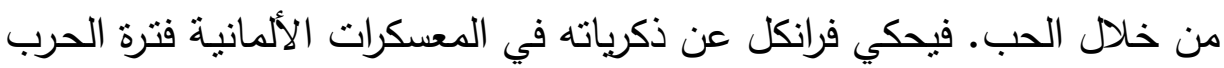
العالمية الثانية وكيف إنه كلما قست عليه الحياة - بعد مقتل كل أهله - وتذكر

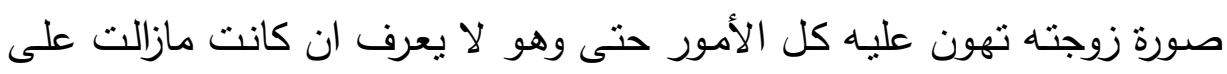

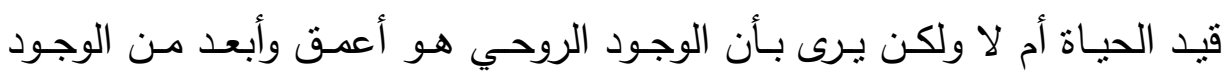

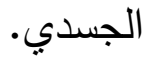
وقد لاقى مفهوم معني الحياة في مجال الصحة النفسية اهتمام الباحثين، حيث ترتبط لدى الإنسان قيمة حياته ورضاه عن ذاته وتقديره لها بالمعني الذي تتطوي لهاه 
عليه حياته والدور الذي يرى أنـه أهل لأدائه في الحياة. (عبدالرحمن سليمان

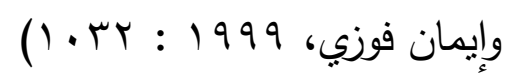

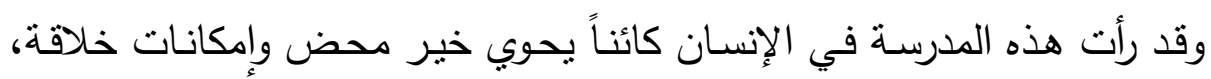

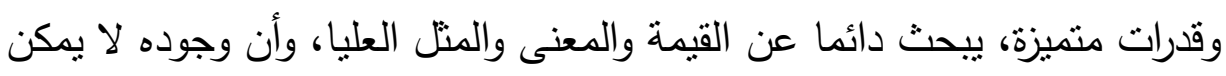

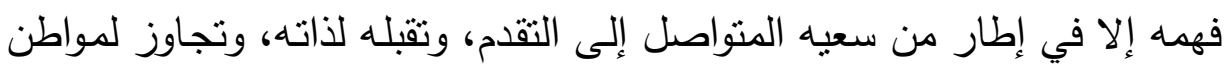
الضعف في صلب تكوينه، وانطلاق صوب الذات وتوكيد الإمكانات، كما أنها تركز علي اكتشـاف معني الحيـاة، وتحقيـق فرديـة العمبل، وجعلـه أكثر تفهماً

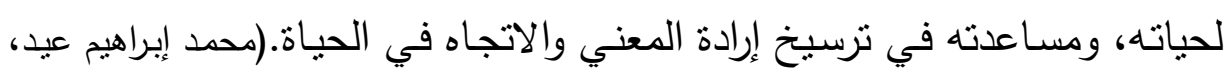
( $r \varepsilon \cdot:$ Y $\cdots T$ بالتالي ووفقاً لما سبق فإن فرانكل برى بأن غياب المعنى في الحياة يلعب

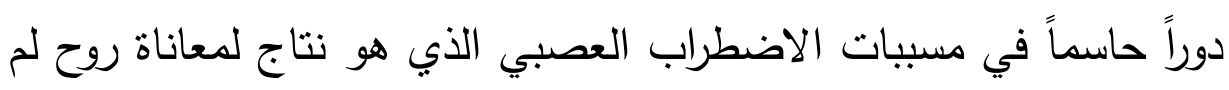

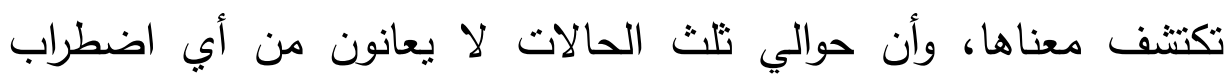
عصبي ولكن يعانون من اللاعقلانية وفقدان الهدف في الحياة. (John Sommers. et al, 2004: 158)

- مشكلة البحث:

يعتبر الإنسان كائن اجتماعي نظراً لأنه يميل إلى العيش داخل جماعات، وتعد

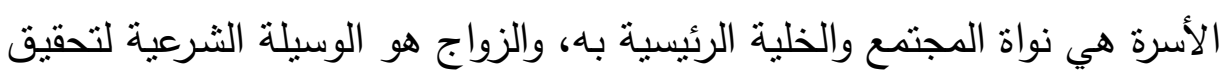
ذلك المطلب، وأن عدم حدوثه يؤثر سلباً على الصحة النفسية والجسمية وقدرة الفرد - سواء كان ذكر أو أنثى - على التوافق والتكييف مع مجتمعهد.

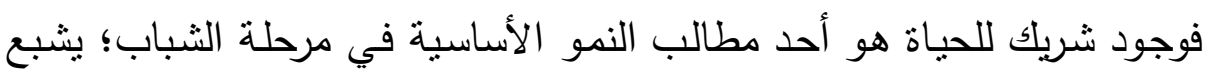

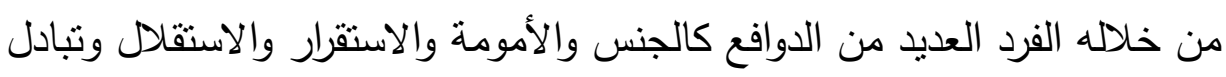

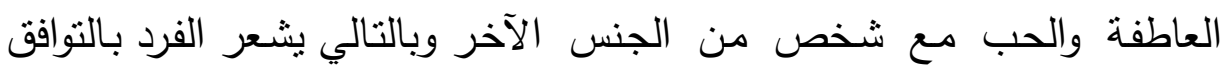

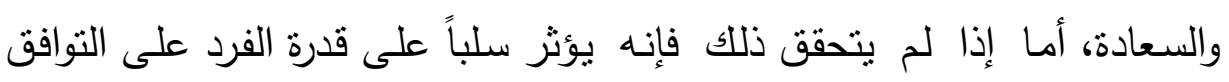

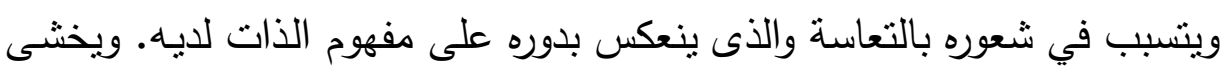


من أن عدم الزواج أو التأخر في سن الزواج قد يؤدي إلى محاولة تحقيق الإشباع

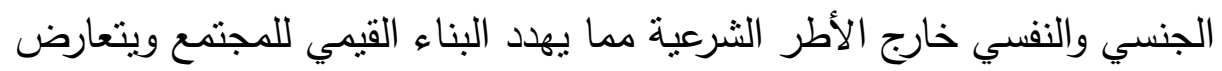

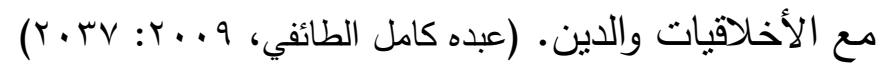

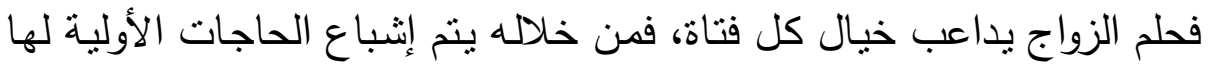
بطرق يرتضيها الدين والمجتمع، كما يتم إثباع غريزة إنسانية لدى المرأة وهي

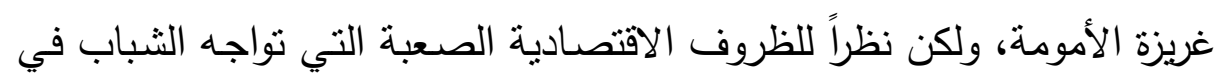

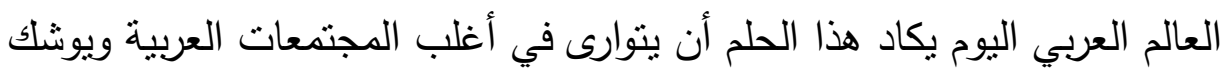

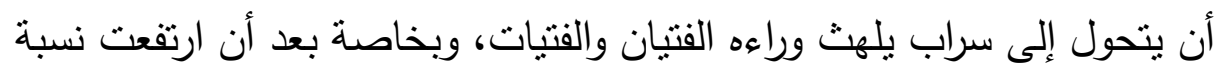

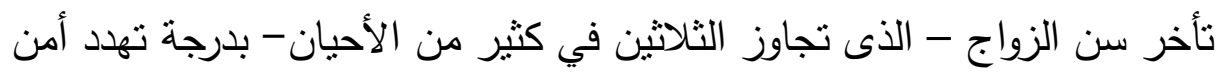

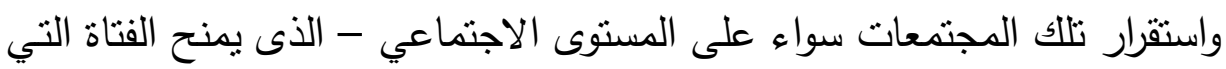
لم تنزوج لقب عانس - أو حتى على المستوى الأمني حيث أصبح الزواج مشكلة

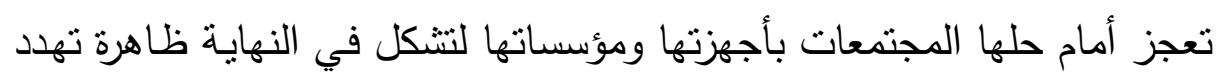
الملابين في العالم العربي عامة وفى مصر خاصة. هذا وقد يترتب عليه العديد من الآلام النفسية والعضوية، وقد تلجيأ الفتاة إلى فيلى

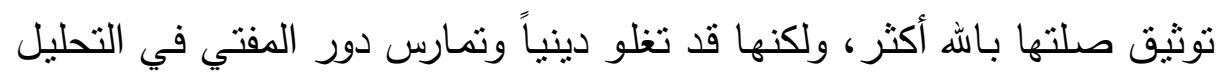

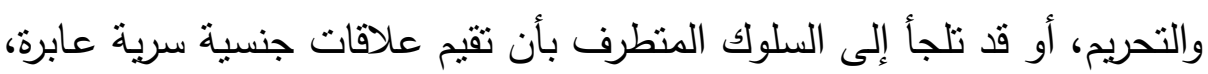
أو تلجأ إلى ما يسمى بالزواج العرفي أو السري لكي تتبع رغباتها الجنسية، باتهات

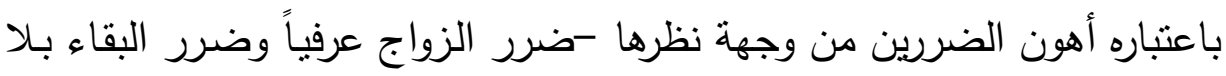

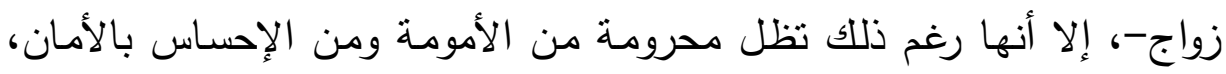
الأمر الذى ينعكس سلباً على صحتها النفسية والجسدية.

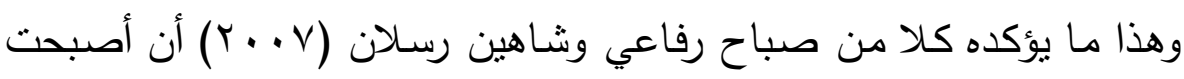
طموحات الفتبات هذه الأيام تتسم بالقلق والتوتر ، بعد أن وصل سن ونداع الفتاة في

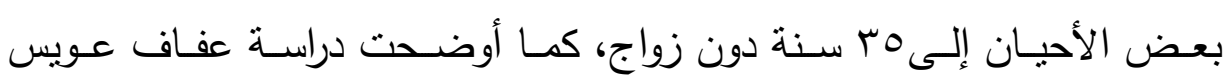

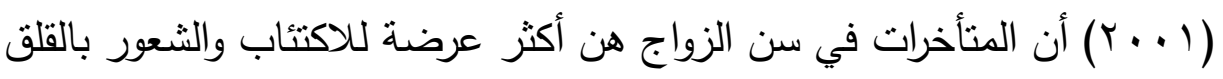


والتوتز والإحساس بالنقص مما يدفع بعض الفتيات للانتحار أو الاتجاه إلى علاقات غير شرعية أو الاكتئاب. ولقد أكدت الإحصاءات الرسمية للجهاز المركزي للتعبئة العامة والإحصاء في الإبي

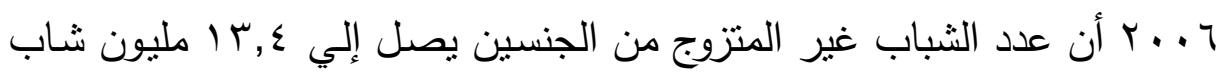

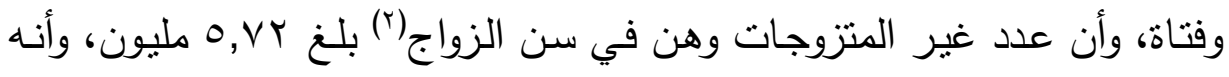

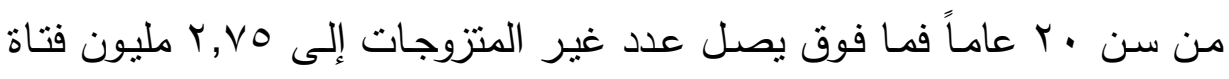

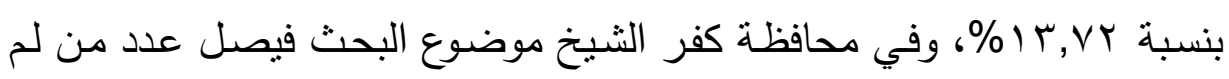

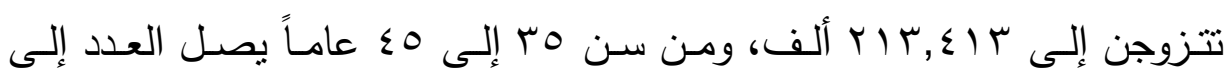
سדז, 7 ألف.

ومن ناحية أخرى نجد أن الاكتئاب خبرة من الخبرات الإنسـانية الثـائعة، فكل

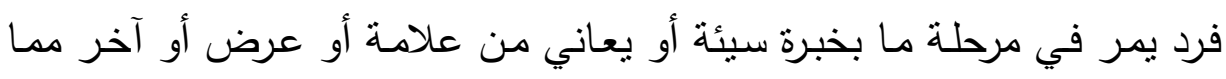

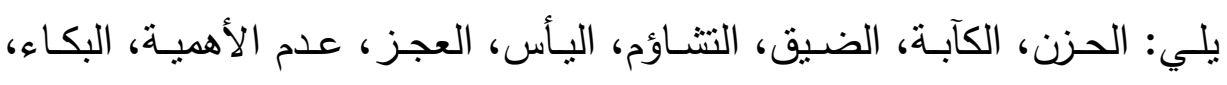

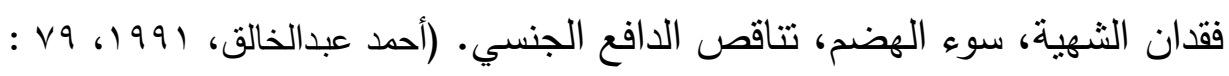
(^. ويشير الاكتئاب إلى شيوع المزاج الحزين وقلة الاهنمام بالنشاطات والعلاقات

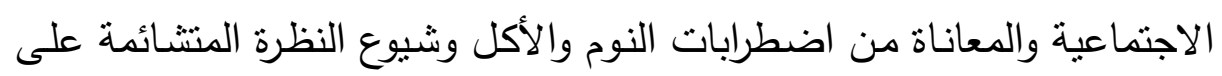
حياة الفرد. (Ivarsson et al., 2006, 321-325) انطلاقاً مما سبق، ومن أن معظم مشكلات تأخر سن الزواج لدى الفتيات ومن

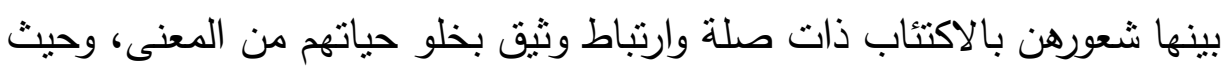

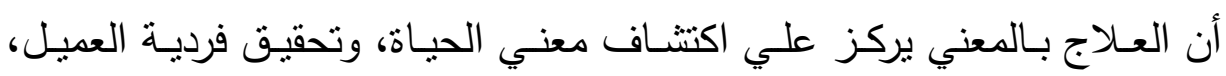
ويجعله أكثر تفهماً لحياته، ومساعدته في ترسيخ إرادة المعني والاتجاه في الحياة.

(Gladding, 1994, 95) 
بالتالي يتضح ضرورة التدخل لإيجاد هدف للفتاة نظراً لأن الضرر الأكبر يقع

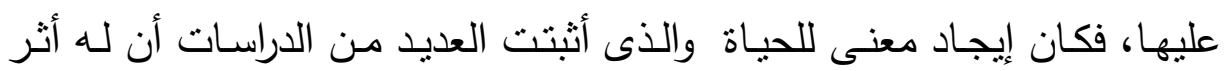

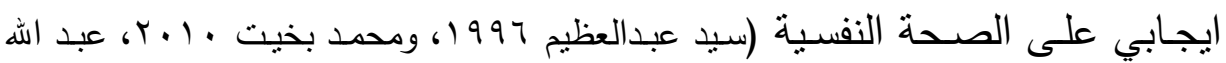
البقمي ع (ب. (T). فالعلاج بالمعنى يركز على معنى الوجود الانساني، وكذللك على سعي الإنسان

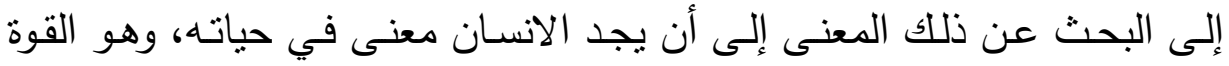

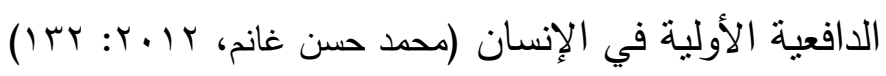
بالتالي يتبين لنا حجم الآثار النفسية المترتبة على تأخر سن الزوان لإندان لدى الفتاة،

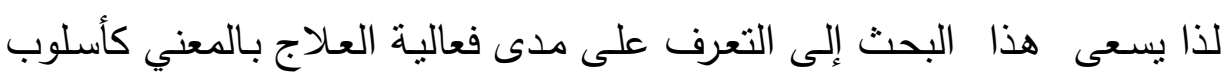
إرشادي لخفض الاكتئاب لدى المتأخرات في سن الزواج. ومن هنا يمكن بلورة مشكلة البحث في التساؤلات التالية:-

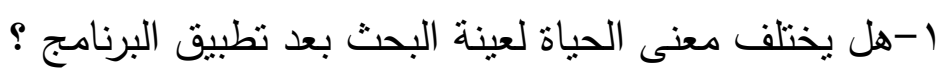

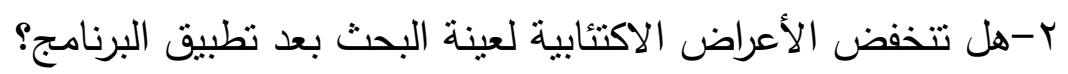
- هدف البحث: الكثف عن فعالية الإرشاد القائم على العلاج بالمعني في خفض الاكتئاب الناتج عن تأخر سن الزواج لدى المعلمات.

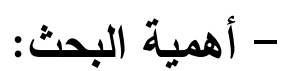
تتمثل أهمية البحث الحالي في:-

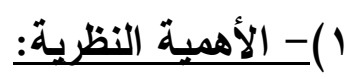
ا .ندرة الدراسات أو البحوث - في حدود علم الباحثان - اهتمت بدراسة العلاج

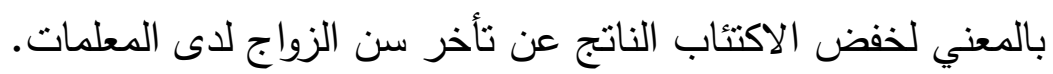

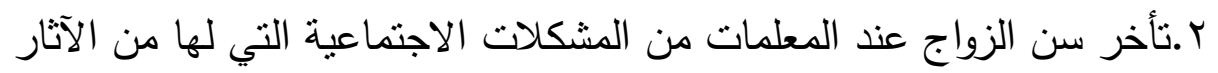
النفسية والاجتماعية الخطيرة، والأخطر عندما تتعكس هذه الأثار على تلاميذهن. 
ץ.المرحلة العمرية التي يهتم بها البحث؛ وهي سن (0ب-0؛) سنة، تمثل سن

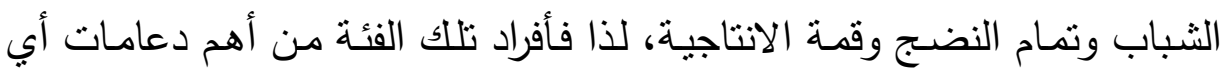

\section{r}

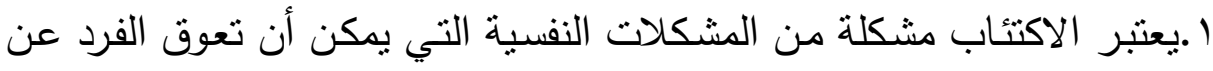

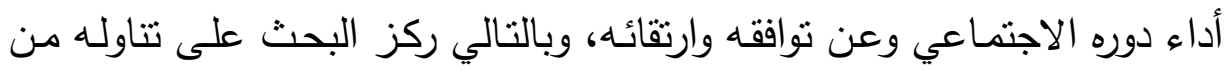

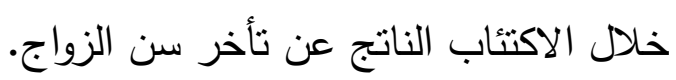

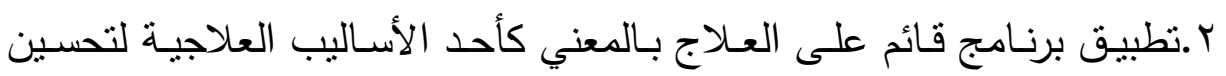

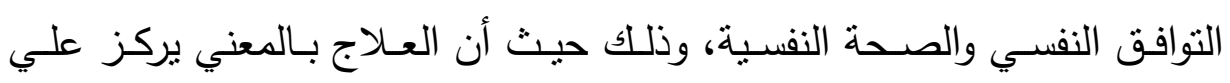
اكتشاف معني الحياة. r.محاولة خفض الاكتئاب الناتج عن تأخر سن الزواج عند المعلمات حيث أنه ينعكس على علاقاتهن مع تلاميذهن في الفصل الدراسي وأثناء العملية التعليمية. - مصطلحات البحث الإجرائية:

\section{Logo-therapy العلاج بالمعني}

يعرف الباحثان "العلاج بالمعنى" إجرائياً بأنه "محاولة الخروج من حالة اللامعني

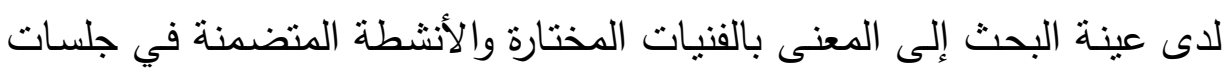
البرنامج، كذللك بإجراءات التطبيق للبرنامج".

\section{r. الاكتئاب Depression}

يعرف الباحثان "الاكتئاب" إجرائياً بأنه: حالة انفعالية مؤفتة أو دائمة، تشعر فيها

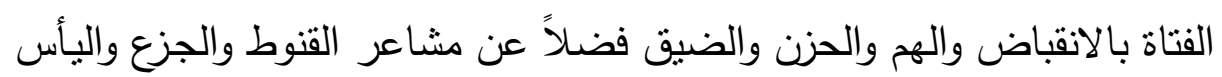
والعجز ، وتصاحب هذه الحالة أعراض سلبية متصلة بالجوانب المزاجية والمعرفية والسلوكية والانفعالية من الحزن الثنديد والميول التثاؤمية، وتتحدد درجة الاكتئاب التهاب من خلال المقياس المستخدم في البحث الحالي. 
Spinster بأخر سن الزواج (العنوسة)

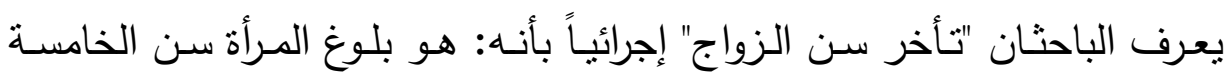

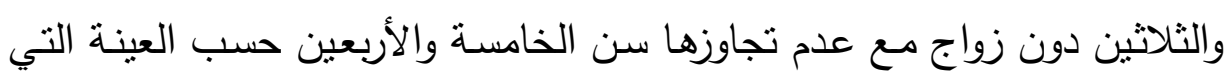
ستجرى عليها البحث.

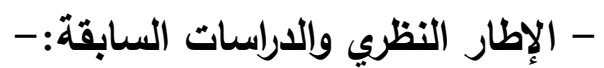

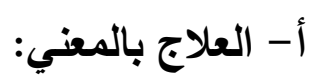

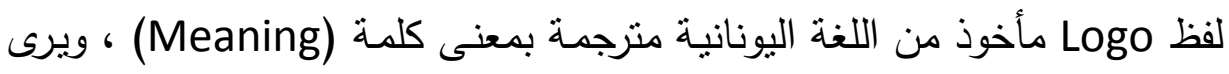

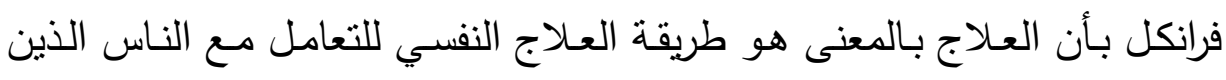

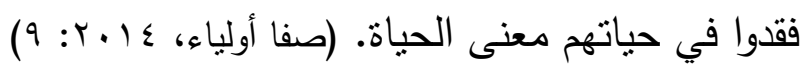
وهو العـلاج بالعقل أو الكلمة أو المعني كمـا عرفهـ فرانكل، كذنلك هو السبيل للخروج من حالة اللامعني إلي المعني ويعد هذا الخروج عملية صعبة يصل إلئ إليها

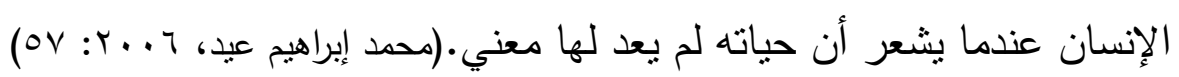

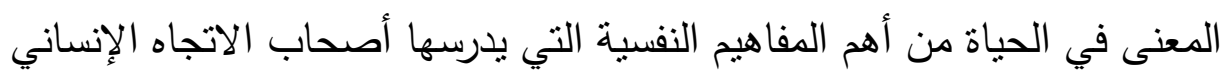

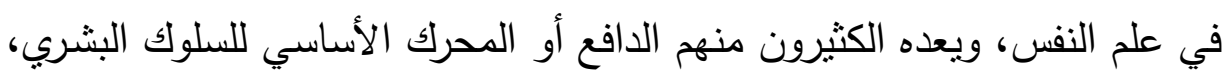

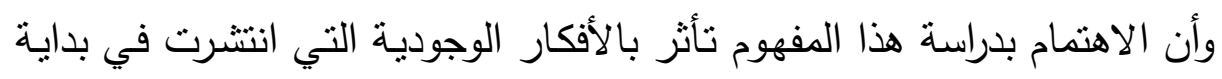

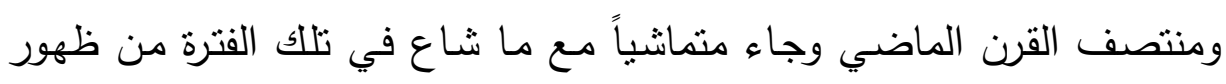
لحالات اللاجدوى والعدمية بين الناس؛ ولم يحظ مفهوم المعنى في الحياة بالاهتمام الكافي من قبل علماء النفس لحين ظهور نظرية فرانكل عن المعنى، لإنى فمنذ بدايات نثوء علم النفس ولغاية ظهور هذه النظرية ظل هذا لناء المفهوم غامضاً

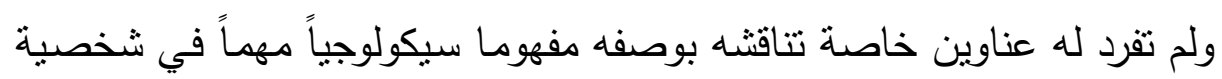
الإنسان أو في صحته النفسية. (Kim, 2001:

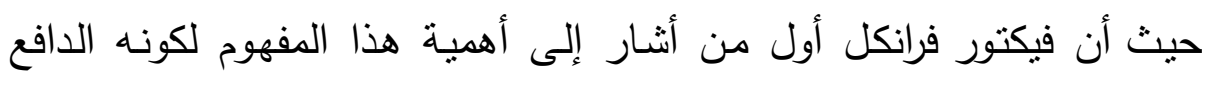

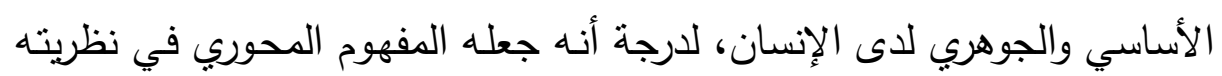

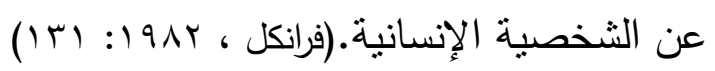


فقدم فرانكل تجربته الأليمة في معسكرات النازية والتي أوحت له بمذهبه العلاجي

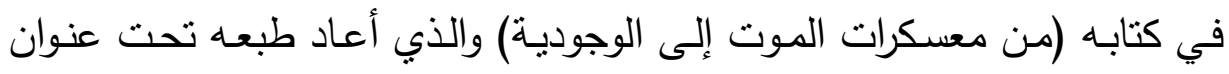

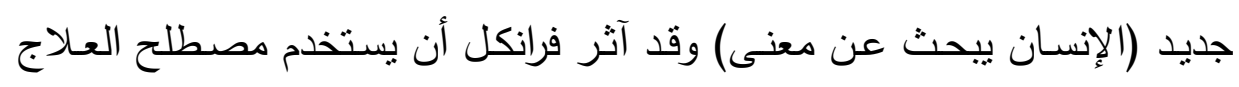

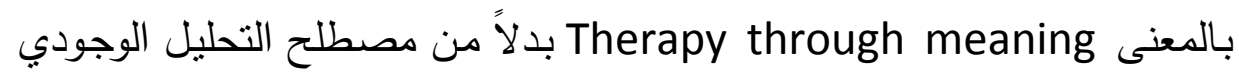
حتى يميز منهجه عن منهج "بيتر فاجنر" من ناحية، ولكي يبرز أن أهم ما يدور

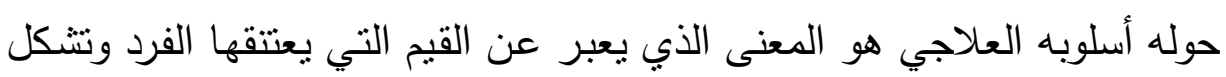

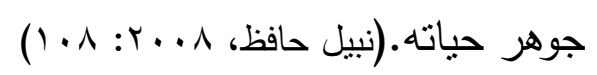

والعلاج بالمعنى بعني إحساس الفرد بأن الحياة ذات قيمة ومعنى بالنسبة لنئ له في

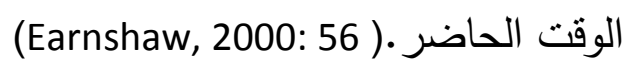
وهو كل شيء يمثنل دلالـة للفرد في حياته مـن خـلال تفسيره لأحداث الحياة، وتكوين فلسفة وأهداف خاصة لحياته، تتاح له من خلال توفير مصادر حقيقية دلهية

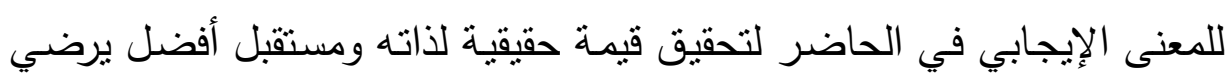

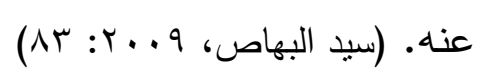

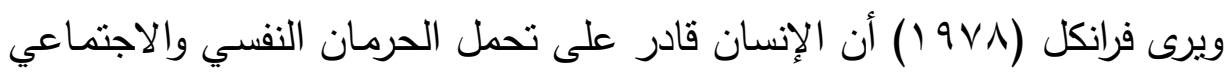

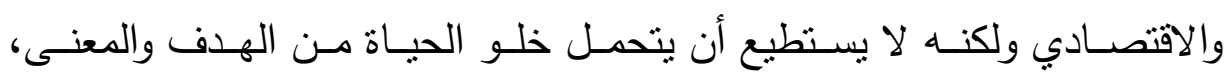

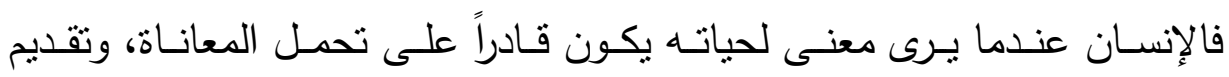

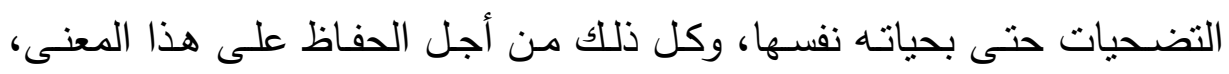
ولكن عندما تفقد حياة الإنسان معناها فقد يضطر الإنسان إلى الانتحار حتى ولو الو

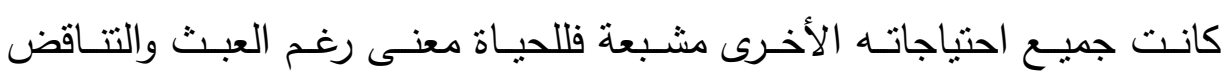

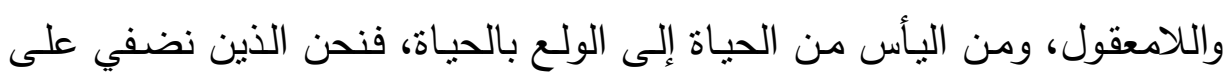

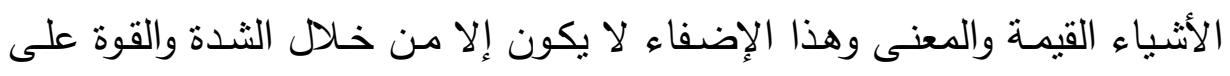

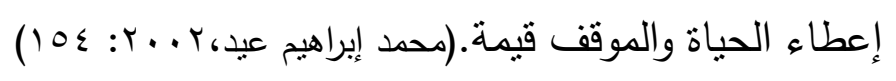


ويقوم العلاج بالمعنى على مجموعة من الأسس الفلسفية وهي:-

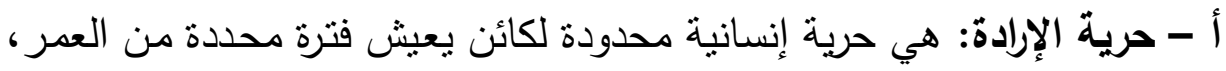
وخلال هذه الفترة يواجه ظروفاً محددة، ولكن هذه الظروف لإنه لا تتحكم في الإنسان.

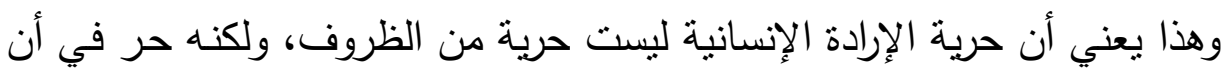

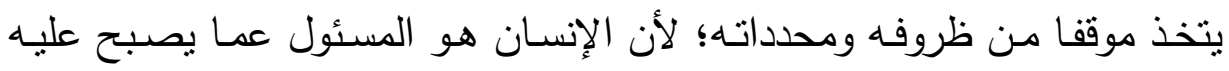

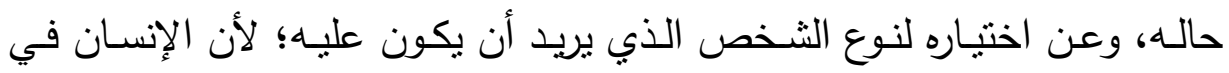
النهاية هو الذي يقرر من أجل نفسه. (Frankl, 1976:63) ب - إرادة المعنى: تعتبر إرادة المعنى هي الركيزة الثنانية التي بستتد إليها العلاج

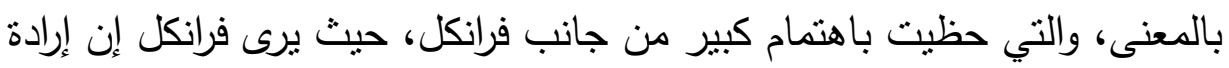

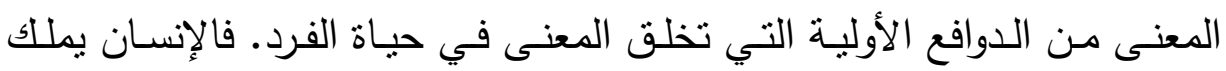

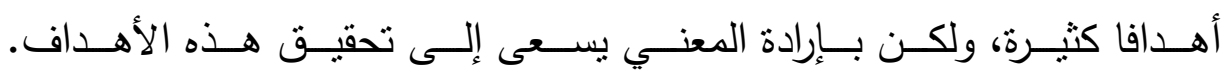
(Frankl, 1978: 17)

ج - معنى الحياة: يمكن تحديد معنى الحياة وفقاً للتصور الأدلري بأنه نمط

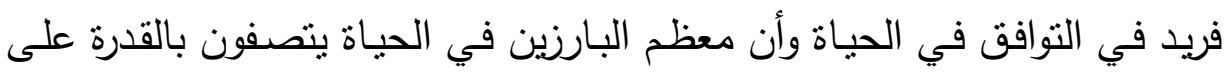

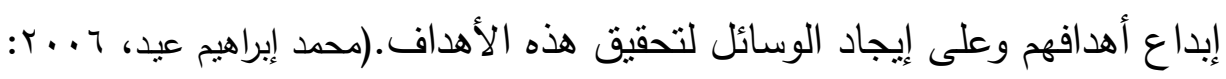
وتتلخص الافتراضات الأساسية العلاج بالمعنى فيما يلي:-

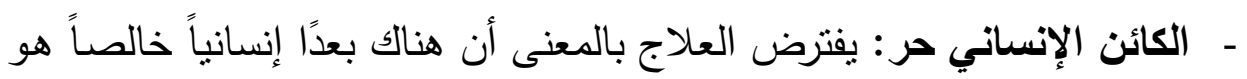

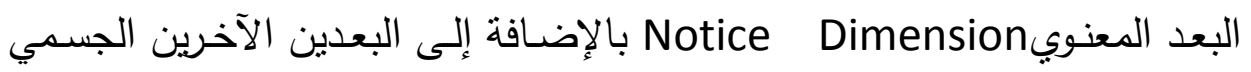

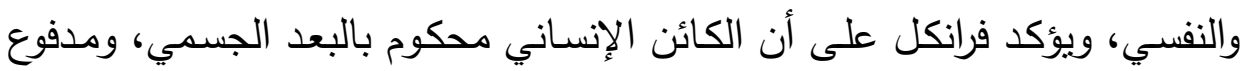
إلى البعد النفسي ولكنه متحرر في البعد المعنوي.(Frankl, 1976:14,15)

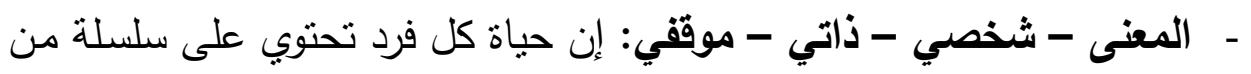

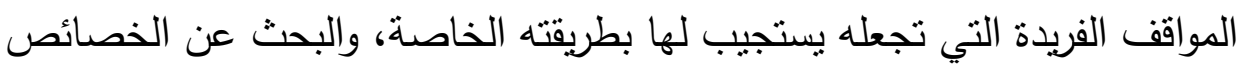

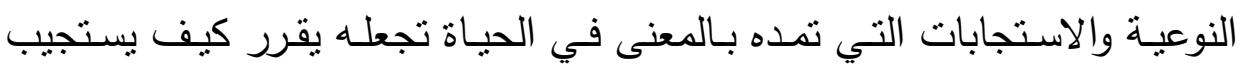


للمهام في الحياة، وأيضا كيف يجد المعنى من خلال تحقيق هذه المهام؛ لأنه في

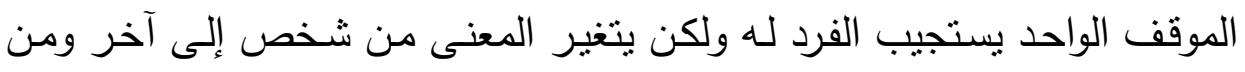
لحظة إلى أخرى. وأكثر من ذلك لا يمكن لأي فرد إعطاء المعنى للآخرين.

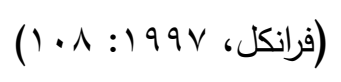
- الحياة تجعل الإنسان يتحدى لخلق معنى لها: استفاد علماء النفس الإنسانيين

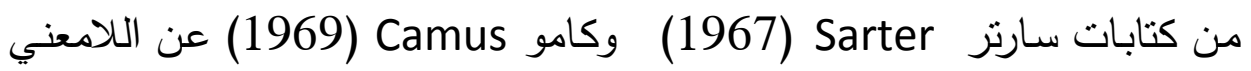
والعبث في الوجود حيث يرى سارتر أن اللامعني هو "العبث الذي يعرفه بأنه كل

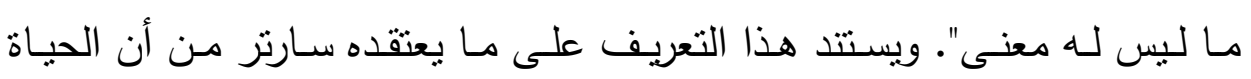
تمضي بغير معنى، وأنها عبث، وأن العبث هو فقدان المعنى، والمعنى في الحياة

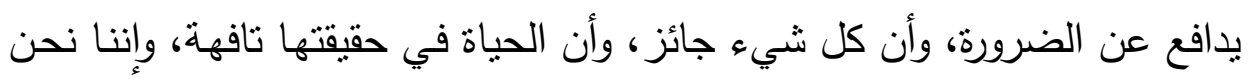

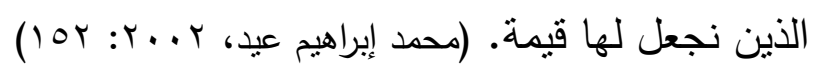
- المعاناة تتضمن قيما ومعاني في الحياة الإنسانية: الحياة الإنسانية تطرح في

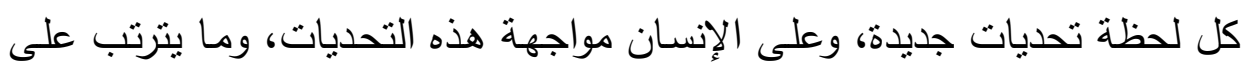
ذلك من قلق وشعور بالذنب وشـعور بالمسئولية، وإذا لم يتحمل الإنسان هدهان معانـاة الآلام ومواجهة التحديات، فإنه يتخلى عن أهم مقومات أصالة وجوده ويهزمه الألم

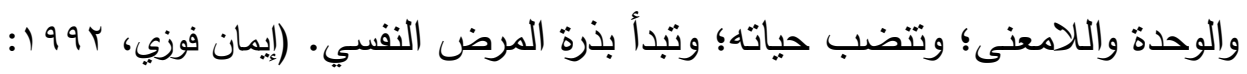
(rAT

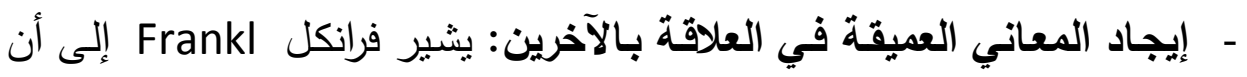

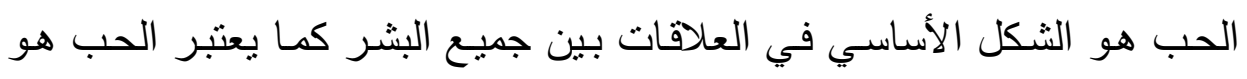

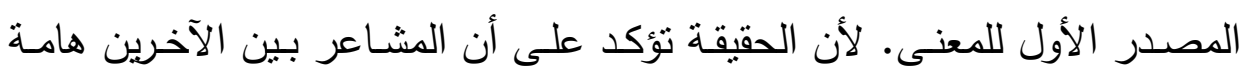
ومفيدة لحياة كل فرد. (Frankl, 1976: 93) - إيجاد المعنى والههف في الحياة يجعل كل شيء في الحياة سهلاً: الثخص

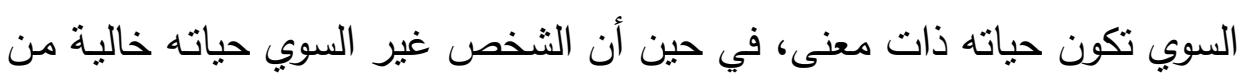


المعساني Meaning lessens ؛ فـاللامعنى في الحيـاة هو الإحسـاس بـالفراغ

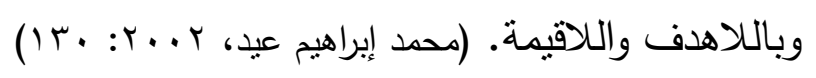

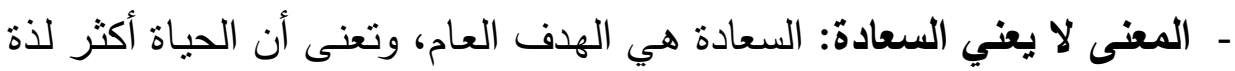

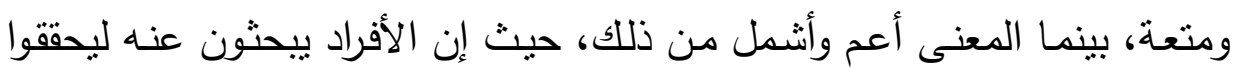

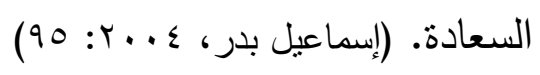

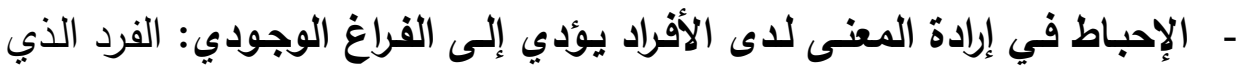

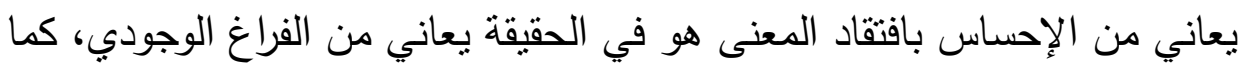

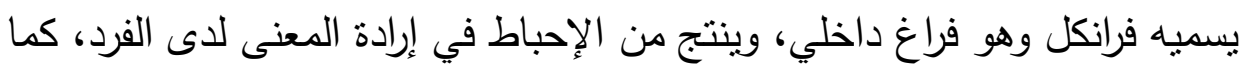

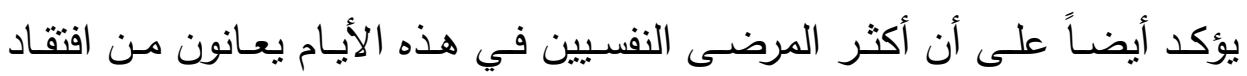
المعنى والهدف من الحياة. (Frankl, 1978: 83-84) ـ - قدرة الإنسـان على التسـامي بالذات: تسامي الذات يعني أن الإنسـان كائن مجاوز لما هو متحقق إلى ما هو غير متحقق، وهذا مكمن قوته وتساميه المستمر.

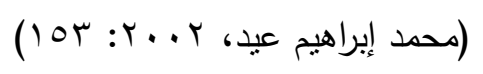
وهدفت دراسة باوم وستيوارت (Baum, \& Stewart, (1990) بعنوان: مصادر

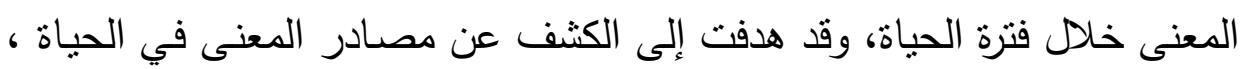

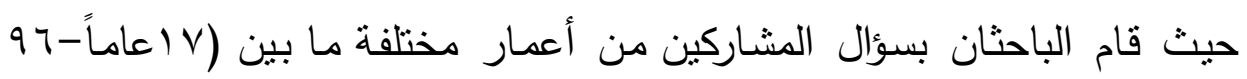

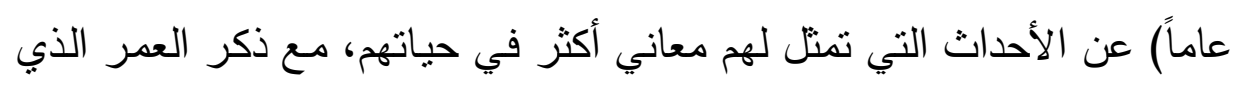

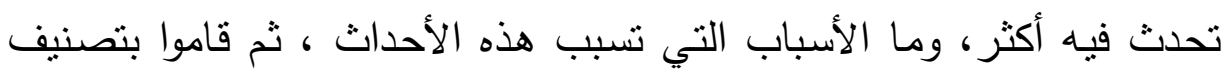

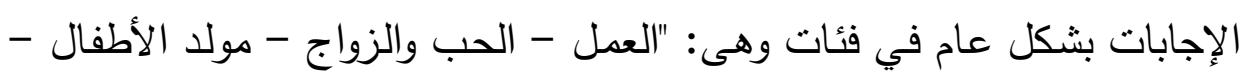

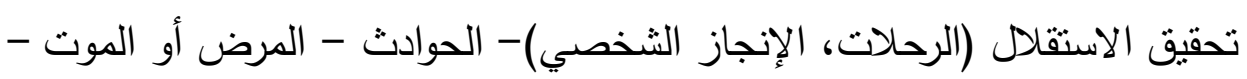

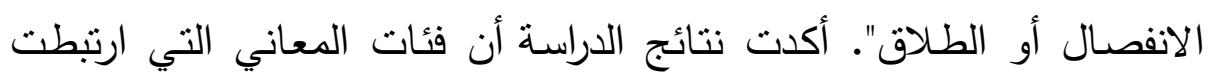

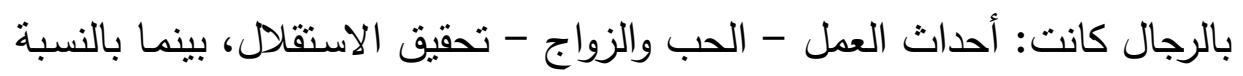

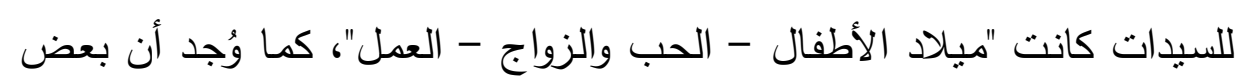
الأحداث قد ارتبطت بالثخص نفسه كالخبرات التي يكونها من الأنشطة التي ولاتي Doi: $10.12816 / 0041722$ 
يمارسها، ومنها ما هو مرتبط بالعالم المحيط به وما يمنلكه للفرد من قيم،

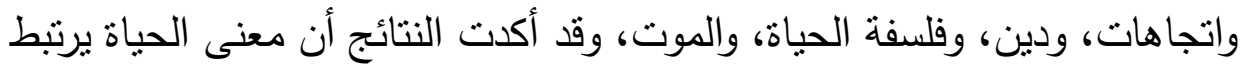

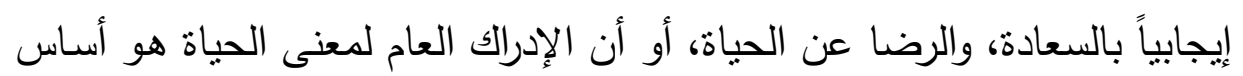
السعادة.

وقد قام سبد عبدالعظيم (997 (1) بدراسـة بعنوان: أثز كل مس العـلاج بـالمعني الوجودي وفنية التفجر الداخلي في علاج الاكتئاب التفاعلي لدي عينة من طلبة لبنة الجامعة، وهدفت إلى التعرف علي مدي فاعلية كل من التحليل بالمعني والتقجر

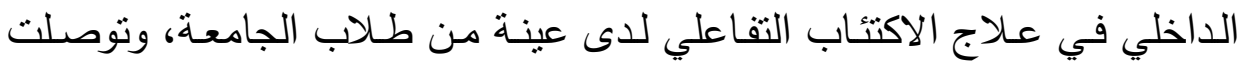

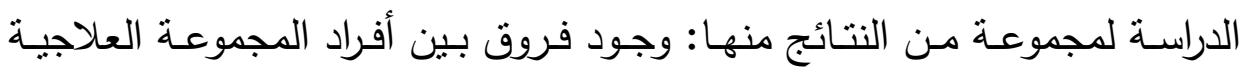

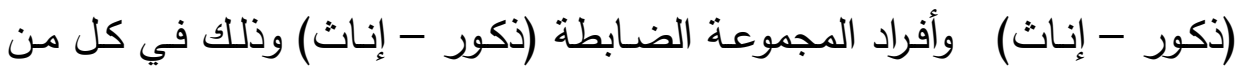
الاكتئاب التفاعلي، اختيار الهدف من الحياة. ما يعني انخفاض درجات أفراد المجموعة العلاجية في الاكتئاب التفاعلي، وزيادة درجاتهم في اختيار الهدف من لاهن الحياة، مما يثير إلي فعالية البرنامج العلاجي للتفجر الداخلي في علاج الاكتئاب التفاعلي. كما قامت إليزابيث (2000) Elisabeth, بدراسة بعنوان: سيكولوجية معنى الحياة،

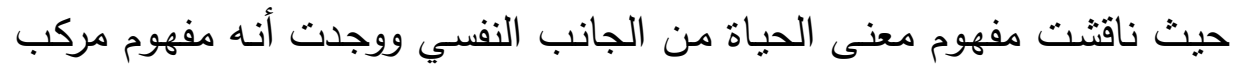
ومجرد وفي بعض الأحيان غامض، وقد أوضحت أن المعنى في الحياة ربما

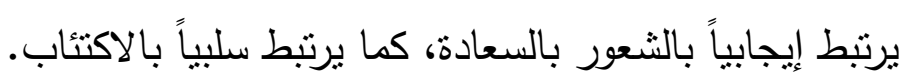

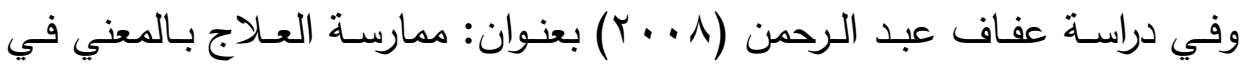

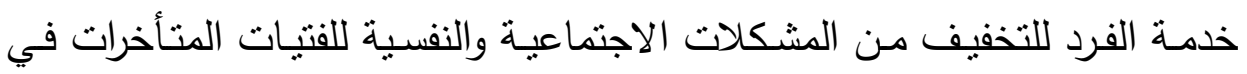
الزواج، وهدفت إلى اختبار فاعلية برنامج للتدخل المهني يعتمد علي استراتيجيات

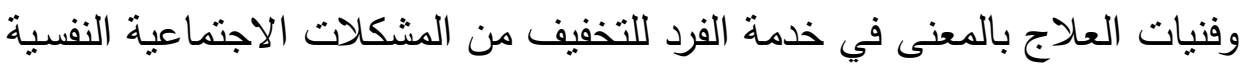

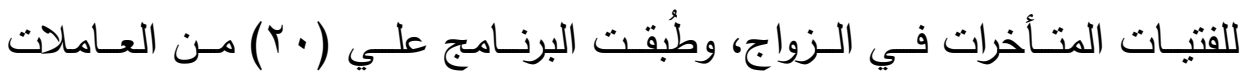

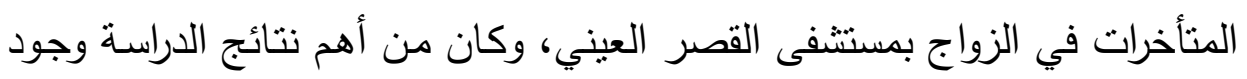


تأثير لبرنـامج التـذخل المهنـي الذي يعتمــ علـي اسـتراتيجيات وأسـاليب العـلاج

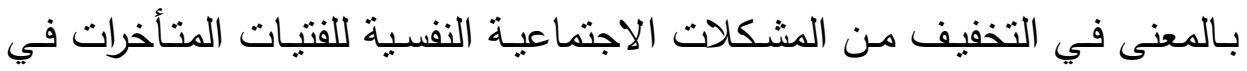
الزواج.

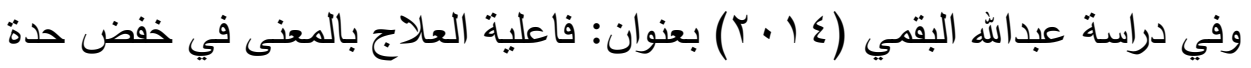

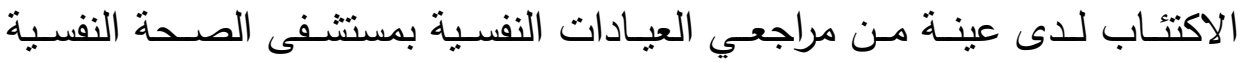

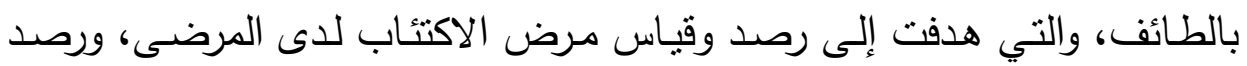
وقياس الثـعور بمعنى الحيـاة للدى المرضىى، وتم تصـميم برنـامج لخفض حده

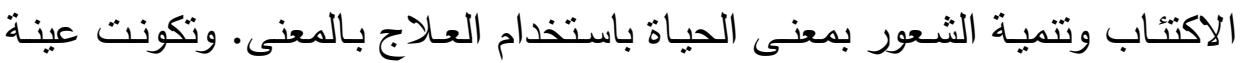

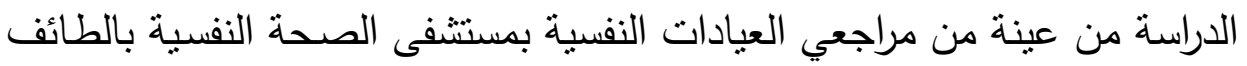
وعددهم (·r) قسموا إلى مجموعتين الأولى تجريبية عددها (· (1) وطبق عليهم برنامج العلاج بالمعنى والثانية ضابطة عددها (• ( ) وطبق عليهم العلاج الدوائي تحت إثراف الطبيب المختص، وتوصلت نتائج الدراسة إلى فاعلية برنامج العلاج

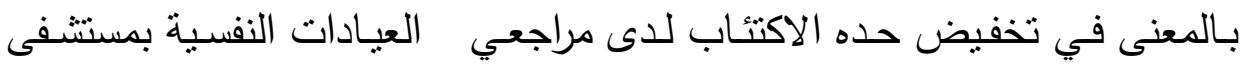
الطائف.

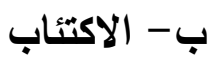

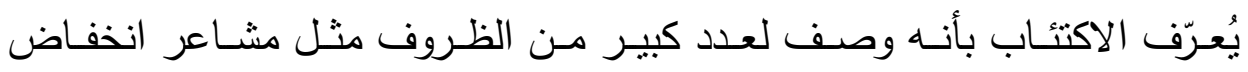

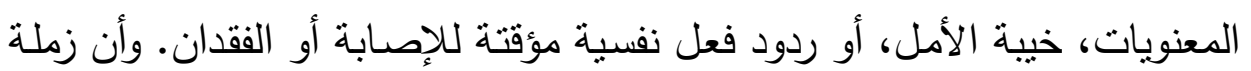
الأعراض الاكتئابية لا تتضمن اضطراب المزاج فقط بل هنالك أعراض مصناحبة الخدية

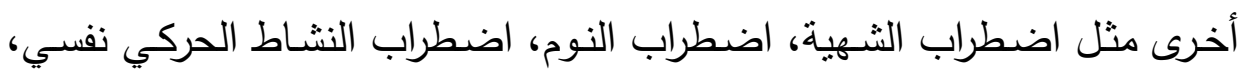

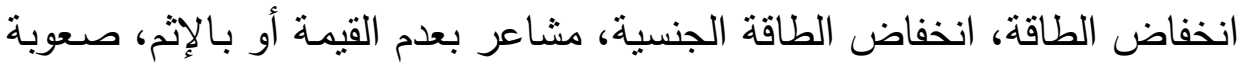

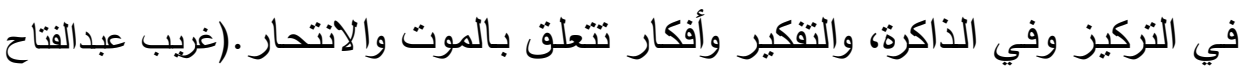
( $(1)-\varepsilon) \cdot$ : r....

فالاكتئــاب اضـطراب لـه جوانـب انفعاليـة ومعرفيـة وبدنيـة، ويمكن أن يتمثلـل الاضطراب الانفعالي للاكتئاب في عدم القدرة على الحب، وكراهية الذات والتي 
قد تصـل إلى التفكير في الانتحسار أو الإقدام الفعلي عليـه. أمـا الاضطراب

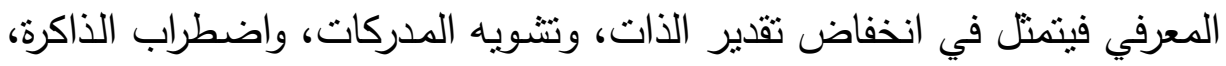

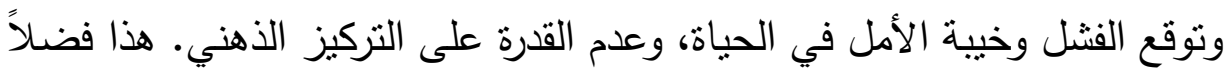

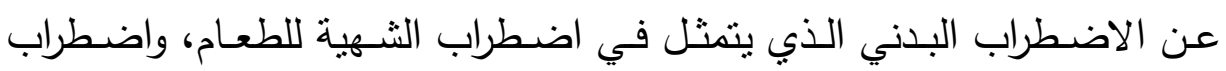
النوم، والعجز الجنسي، واضطراب الجهاز العصبي، والصداع، والإنهاك، وكثرة

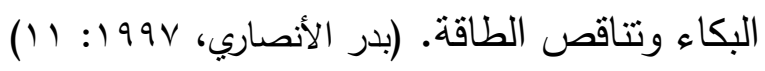

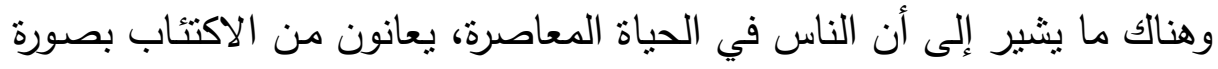

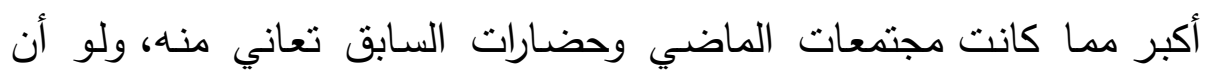
الأقدمين عرباً وغير عرب عرفوه ووصفوه، وأعطوه كثيراً من الأسماء والمصطلحات التي أنثارت إلى مرارة الإحساس بـه وآلام المعاناة منـه.

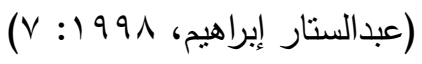

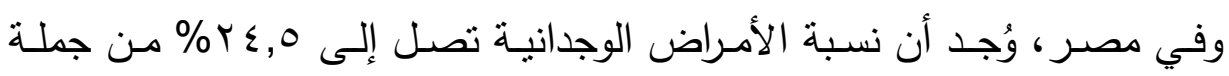

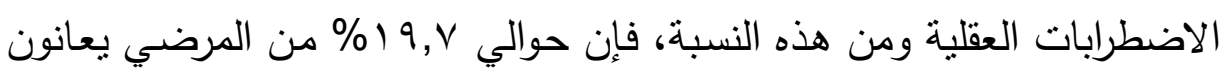

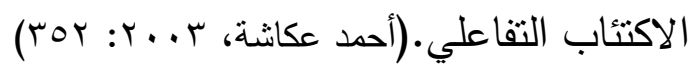

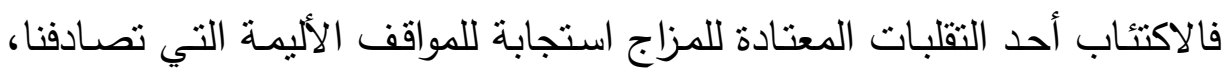
وهو أحيانـاً علامـة من علامات مرض مـا، بل هو موجود في الغالب لدى كل

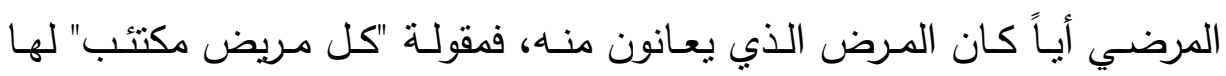
نصيب كبير من الصحة. أوكل مريض يجب أن يكون كذللك، والدفهوم الأهم

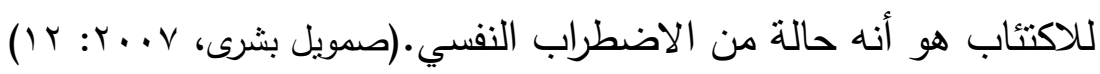

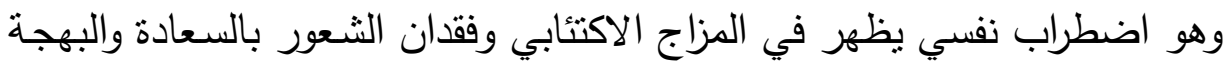
ومشاعر الذنب واحترام للذات منخفض، ونوم وشهية مضطربة، وطاقة منخفضة وتركيز قليل، ممـا يؤدي إلى عدم قدرة الفرد علي القيام بمسئولياته اليوميـة". (Traywick, 2007: 1)

والاكتئاب وصف لعدد كبير من الظروف منل مشاعر انخفاض المعنويات، خيبة

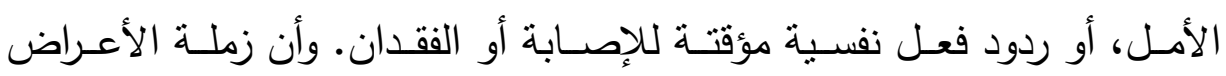


الاكتئابية لا تتضمن اضطراب المزاج فقط بل هناك أعراض مصاحبة أخرى مثل

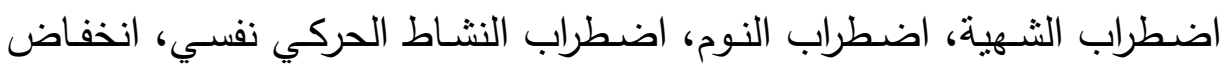

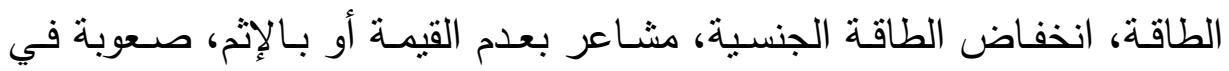

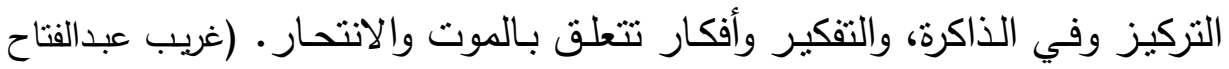
$(\varepsilon)-\varepsilon) \cdot$ : r.... كما أن الاكتئاب يحدث نتيجة لانسحاب مصادر التعزيز المعتادة أو غيابها من

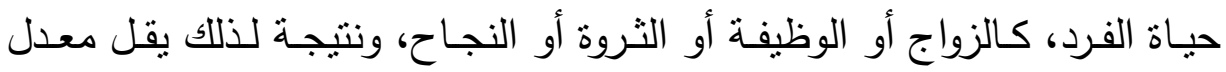

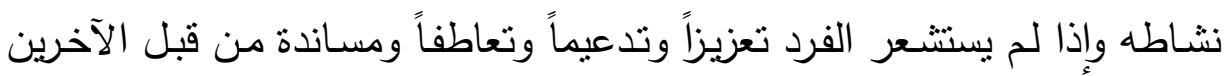

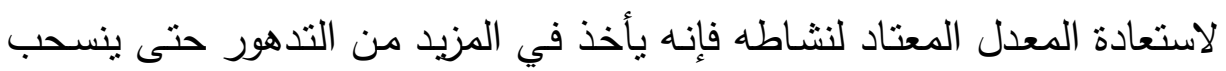

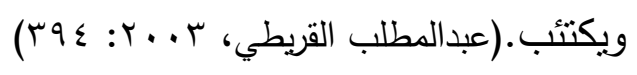

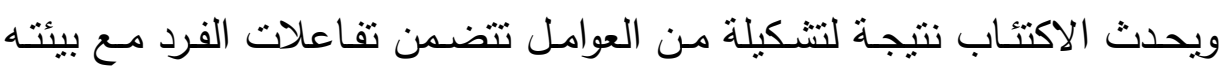

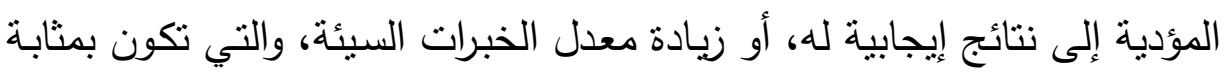
عقاب له. (أحمد عبدالخالق، ومحمد الصبوة، 1997 1: 101)

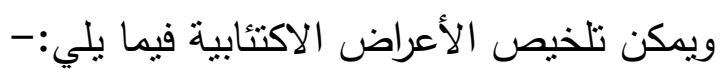
1. أشعور بالاكتئاب والزهق والملل. r. اضطرابات بالنوم وقد تكون في صورة صعوبة في النوم أو كثرته.

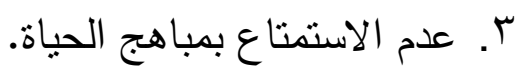
ع. فقدان الثهية للأكل أو الإفراط في الأكل بشراهة. ○. سرعة التعب من أي مجهود. 7 7. صعوبة التركيز والتذكر واتخاذ القرارات.

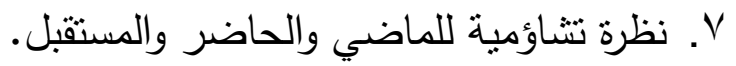
^. التقكير في إيذاء النفس أو المحيطين كالانتحار أو القتل.

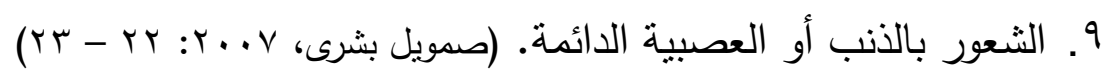


ففي دراسة "كولين ليث, Colin Leath" (1999) بعنوان: خبرة معنى الحياة وفقاً للتصور النفسي، والتي هدفت إلى إعداد مراجعات للاراسات النفسية التي تتاولت داتل

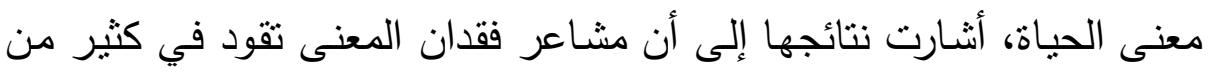

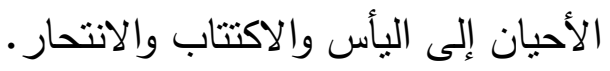

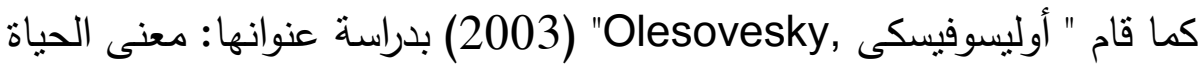

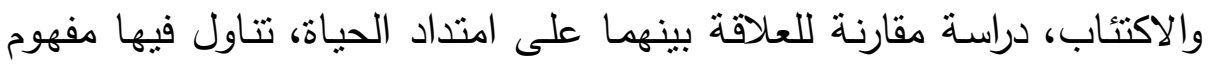

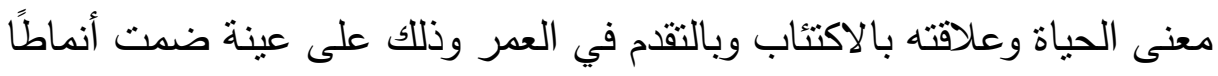
مختلفة من الطلاب وأفرادًا من كبار السن وبلغ عددهم (1) منطوعا تم تقسيمهم إلى ثلاث مجموعات فرعية عمريـة، وقد استخدمت في الدراسـة عدة أدوات من فن

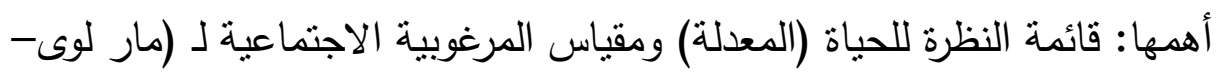

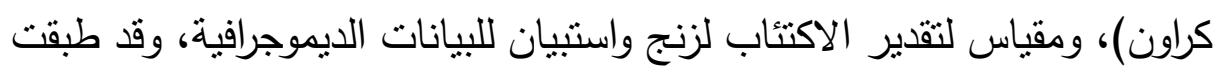
أساليب إحصائية منتوعة مثل: تحليل الانحدار المتعدد واختبار فيشر التحويلي أوضحت نتائج الدراسة وجود علاقة سالبة بين معنى الحياة والاكتئاب في كل العل المجموعات العمرية، بينما لم توجد فروق ذات دلالة إحصائية بين معنى الحياة والتقدم في السن عند حدوث الاكتئاب وحتى في أصغر فئة عمريه.

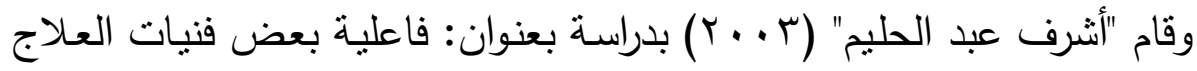
الوجودي في خفض الاكتئاب لدى عينة من المسنين، وهدفت الدراسة إلى اختبار فنيات العلاج الوجودي في تخفيف مشاعر الحزن والاكتئاب لاى عينة من نزلاء

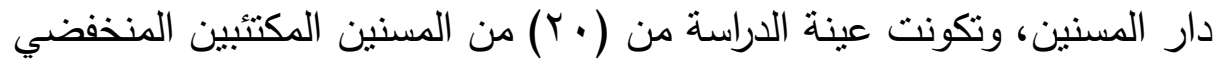
الثعور بمعني الحياة كمجوعة تجريبية، و (20) من المسنين المكتبكين

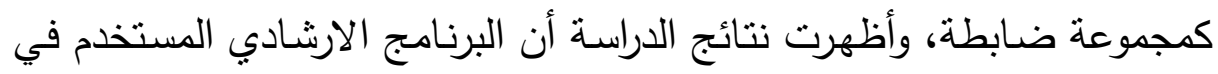

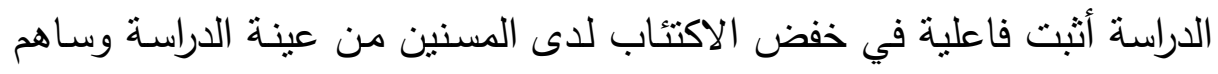
في شعورهم بمعني الحباة من جديد وبالتالي عودة الأمل لديهم وشعورهم بالفاعلية ملية والكفاءة. 
وقدم ماسكارو (2005)Mascaro) دراسـة بعنـوان: دور المعنى الوجودي في تعزيز الأمل والوقاية من أعراض الاكتئاب، وقد هدف إلى اختبار الفرض القائل

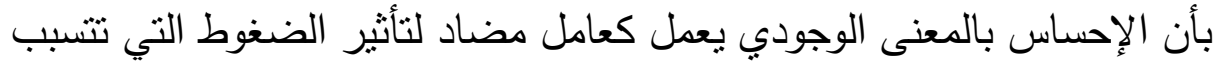

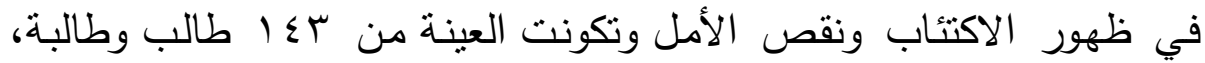
وأظهرت النتائج وجود علاقة ارتباطية سالبة بين الإحساس بالمعنى الوجودي

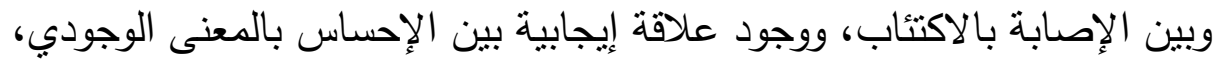

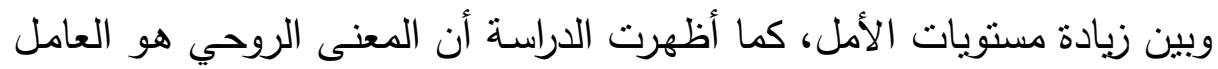
المضاد الأول ضد ضغوط الحياة اليومية والاكتئاب. ج- المتأخرات في سن الزواج:

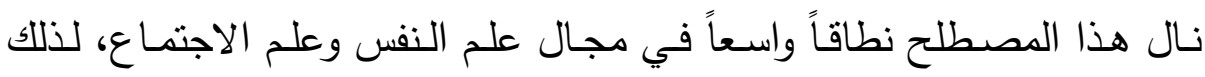

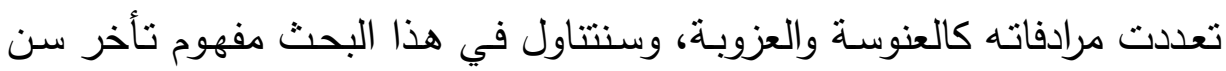

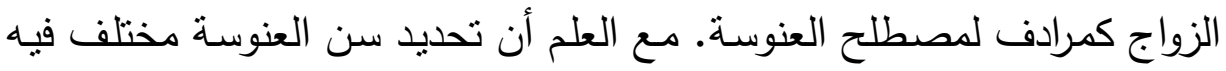
بين الناس، فمنهم من يعتبر الفتاة عانساً إن بلغت سن الثلاثين، ومنهم من لم لم يعدها وإن بلغت أكثر مـن ذلك؛ ومـن التعـاريف التـي حاولت الإلمـام بهذين المرادفين نذكر : المان التعريف اللغوي: يقال عنست الجارية، تعنس، عنوساً فهي عانس والجمع عنس

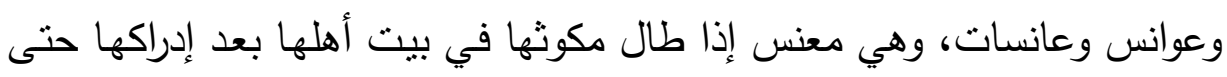

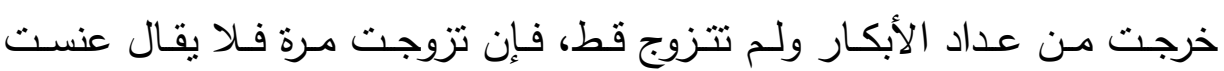
(r) (محمود المسعدي، (1991) ويقول الثيخ (منصور صالح المنهالي، ب.ت) العنوسة أنها "تأخر سن الزواج"،

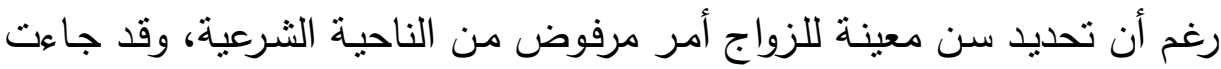

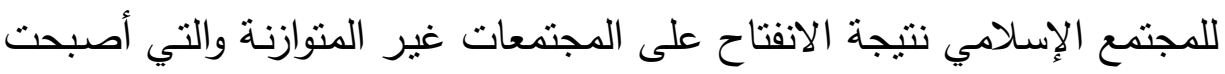

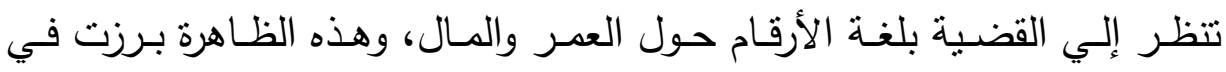
المجتمع نتيجة عدد من العوامل المتعلقة بارتفاع المهور وتكاليف الزواج وعزوف Doi: 10.12816/0041722 
بعض الأولياء عن تزويج بناتهن للكفء والتعذر بأعذار عرفية وعصبية للفهم الخاطئ بأن التعليم يتعارض مع الزواء نُونج

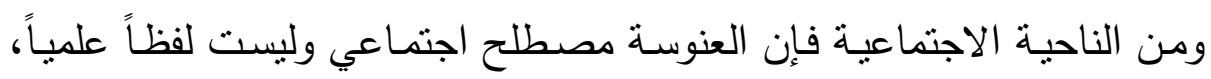

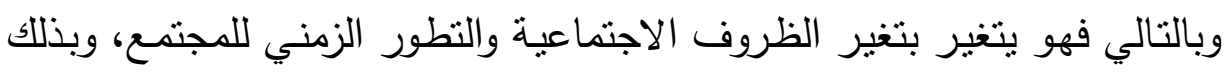

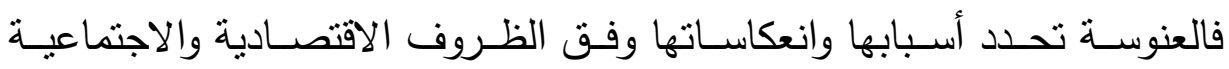

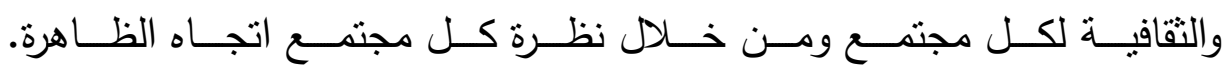

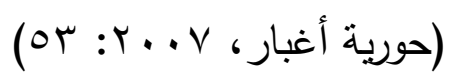

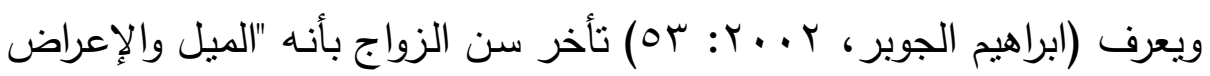

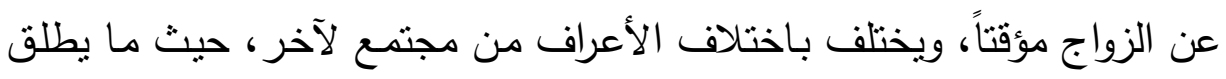

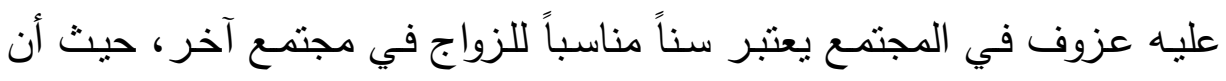
البلوغ يختلف باختلاف حرارة الجو والبيئة الاجتماعية".

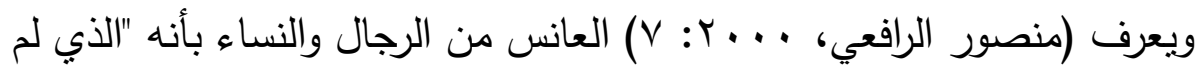

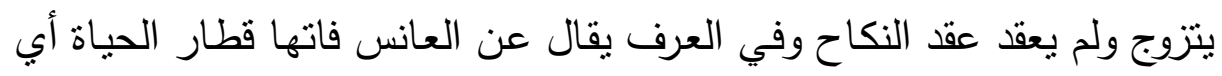

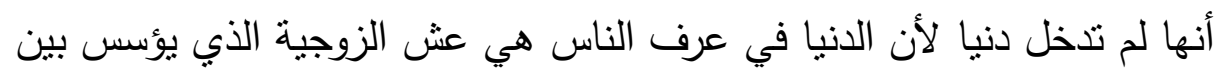

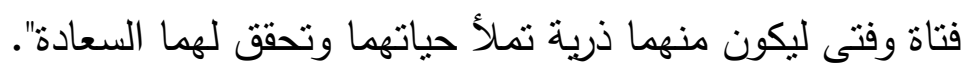
ويقصد بالتأخر في سن الزواج تجاوز الفتاة سن الزواج العرفية وهي ليست

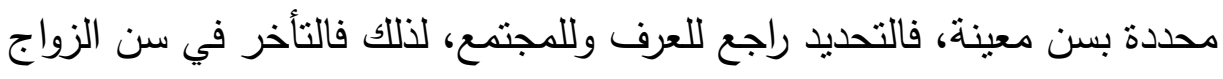
تختلف من مجتمع لآخر كما تختلف لاى الدول العربية والإسـلامية عن الدول

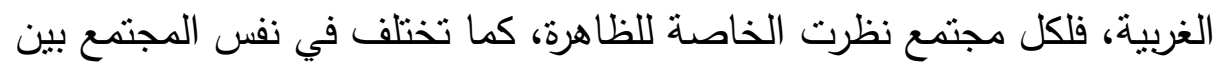
الريف والحضر ، والعرف السائد في المجتمع يعرف العانس من الرجال والنساء

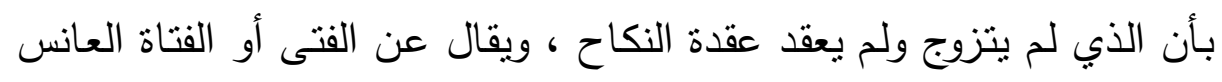

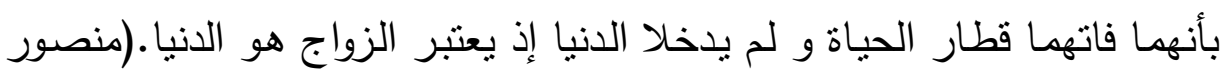

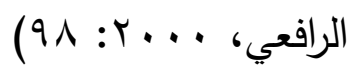




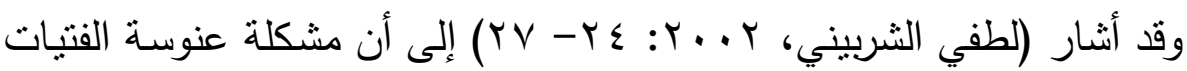

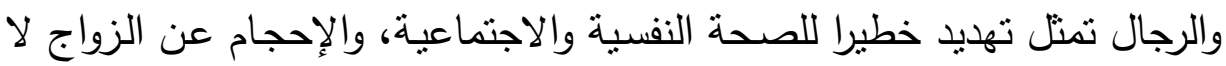
يقتصر فقط على العوامل الاقتصادية التي تتسبب في صعوبة إنمام الزواج ولكن

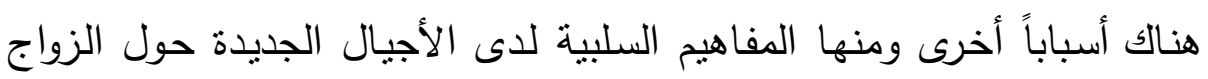

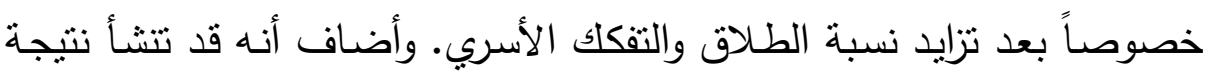

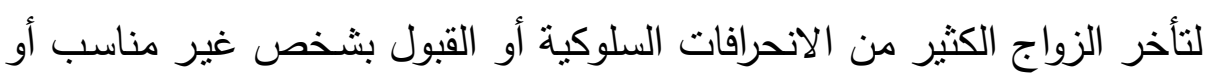

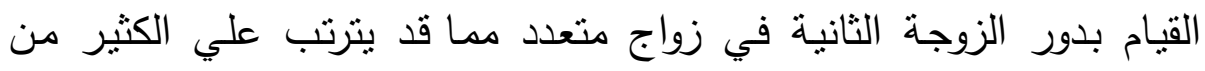

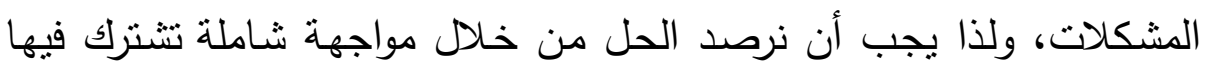

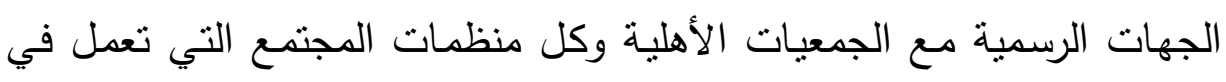

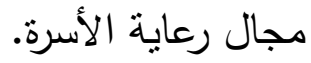
ويرجع عزوف الشباب عن الزواج إلى أسباب متعددة أهمها التغيرات الاجتماعية

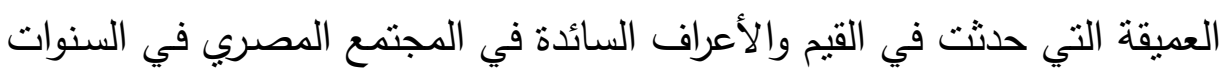
الأخيرة مثل اللامبالاة وعدم الرغبة في تحمل المسئولية، والإحباط العام وفقدان

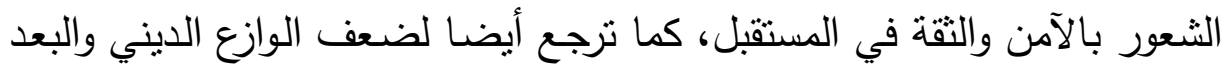

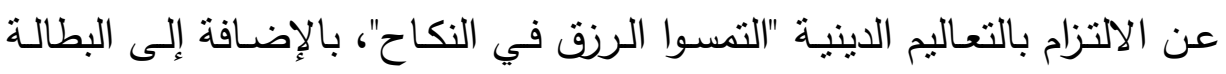

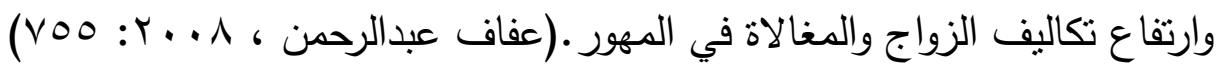

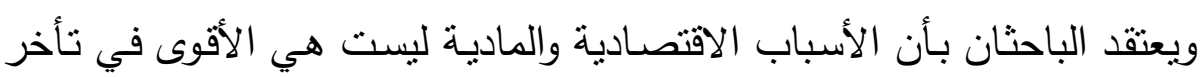

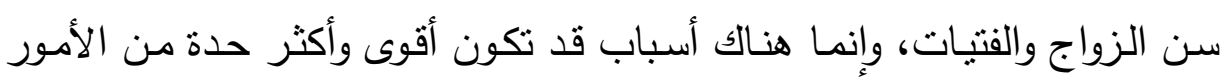
الاقتصادية والمادية ومنها مثناً: 1-العادات والتقاليد : ومن أهم العادات والتقاليد بالمجتمعات العربية عموماً هو ومادية

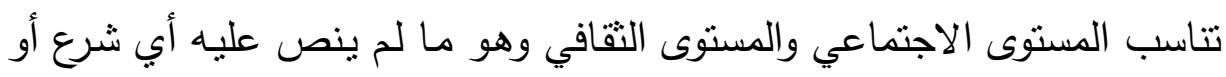

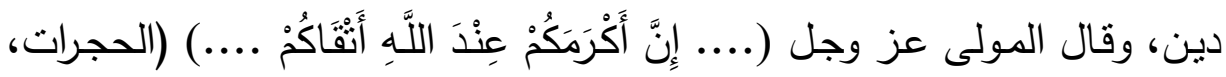

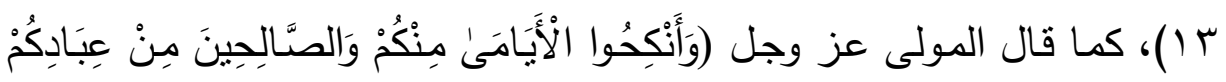

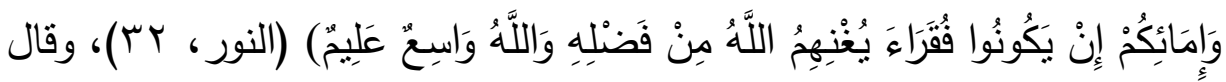
Doi: 10.12816/0041722 


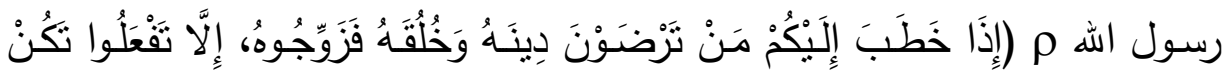

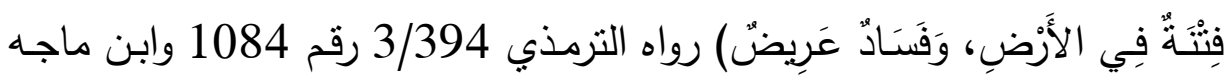

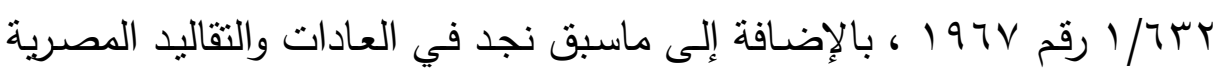

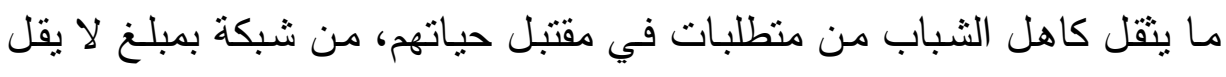

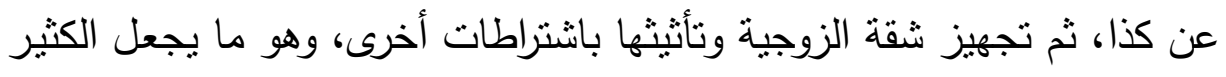

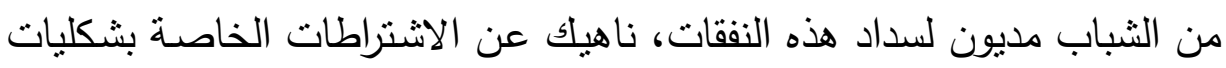
قد تقسد الزواج أساساً متل (قائمة المنقولات).

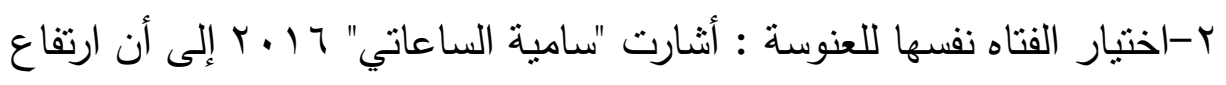

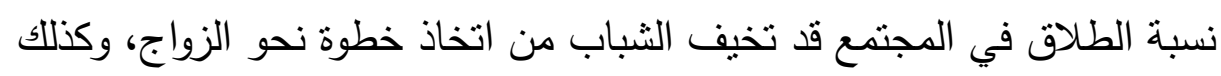

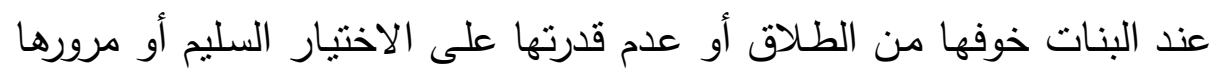

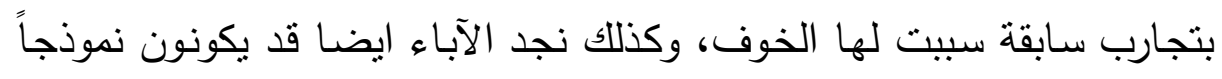

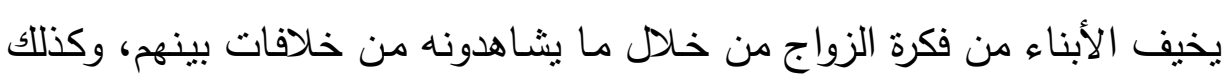

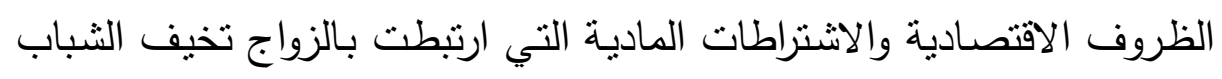

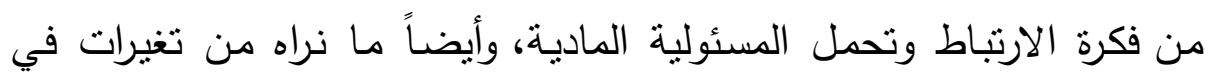

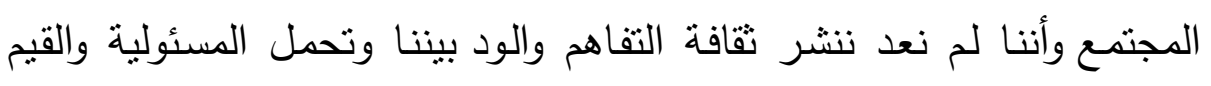

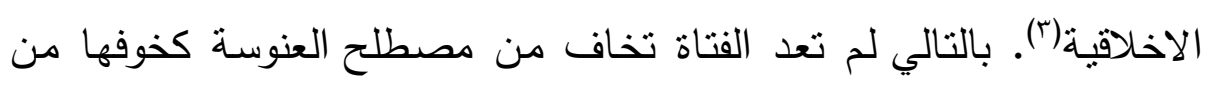

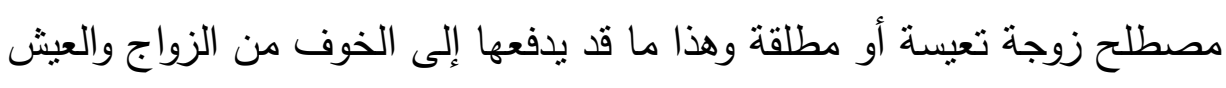
في أحضان العنوسة بإرادتها.

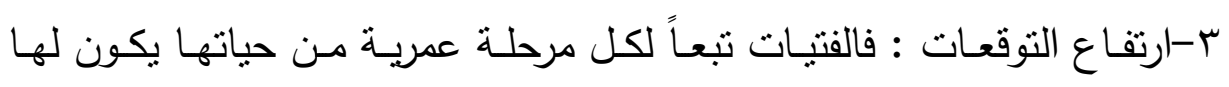

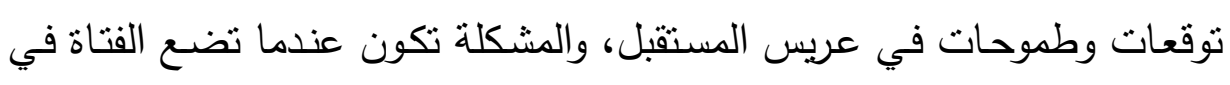

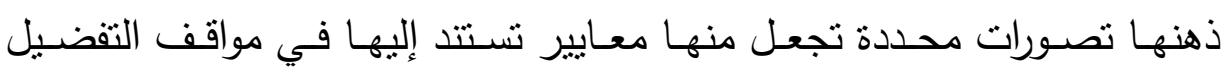


والاختيار لا يتم التتازل عنها منها: مستوى التعليم (دكتوراه - ماجستير - مؤهل

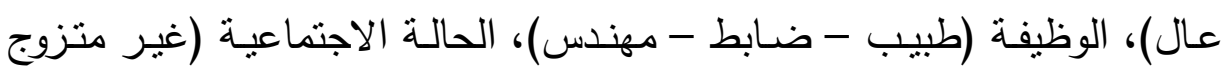

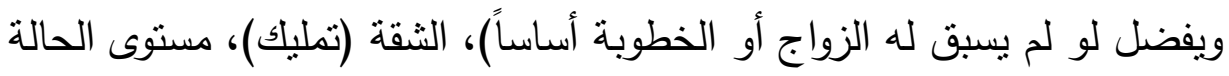

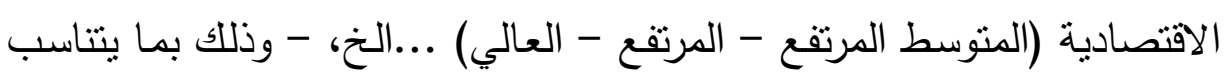
مـع مستواها التعليمي أو الوظيفي أو الاجتماعي أو الاقتصادي - ثم تبدأ تقل

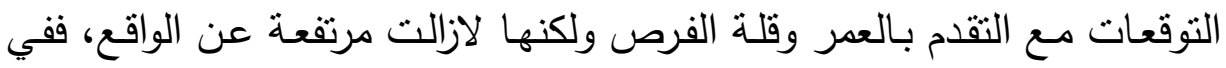

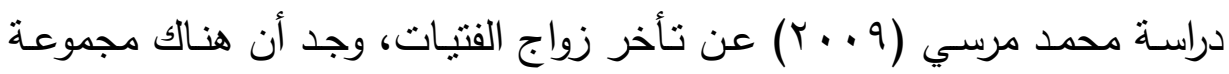

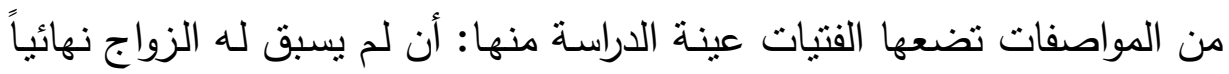

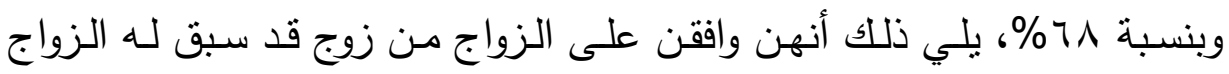

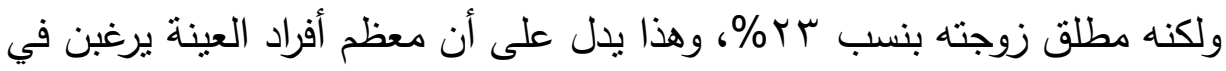

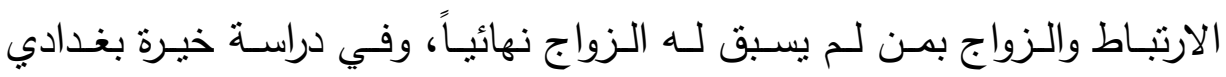

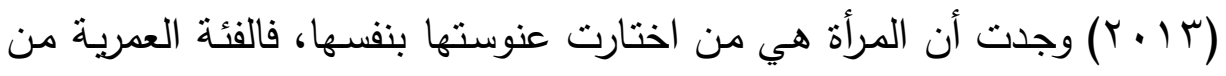

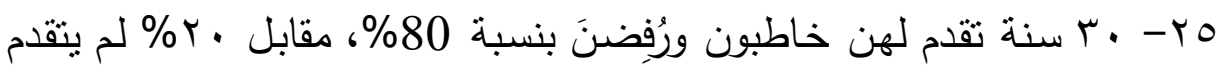

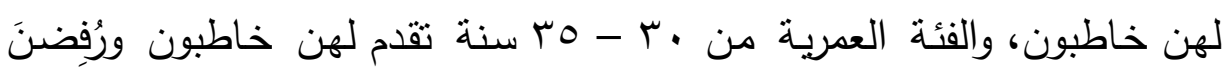

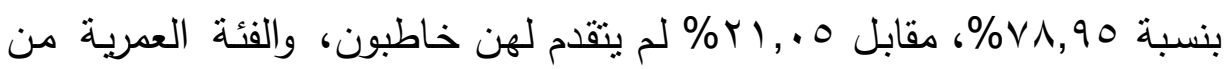

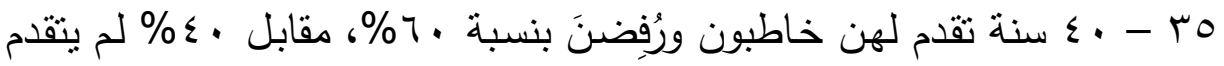
لهن خاطبون. وكانت أسباب الرفض تتلخص في : الثخص الذي تقدم غير مناسب، رغبة الفتاة في إكمال دراستها، التجارب السابقة التي مرت بها الفتاة من

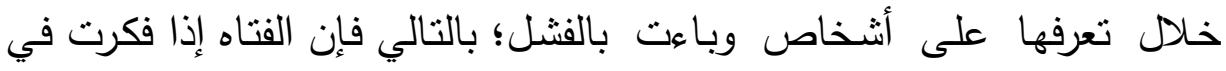

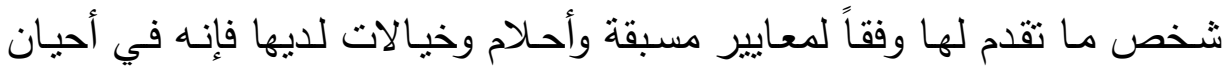
كثيرة تقوم برفضه دون تفكير في حالة عدم استيفاءه لهذه المعايير .

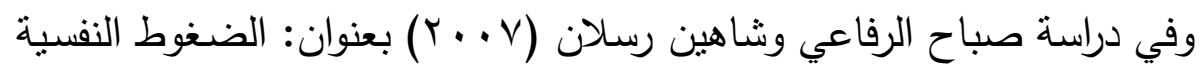

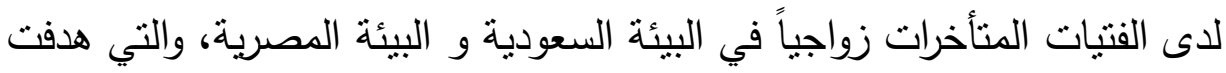
إلى التعرف على الضغوط النفسية لدى الفتبات المتأخرات زواجياً، وقد أظهرت Doi: $10.12816 / 0041722$ 
نتائج الدراسة عدم وجود فروق بين البيئة المصرية والبيئة السعودية في الضغوط النفسية لدى الفتيات المتأخرات زواجياً.

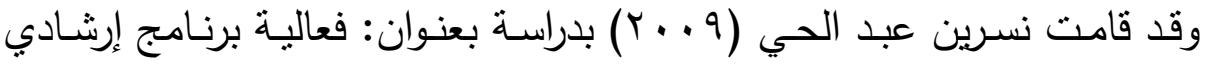

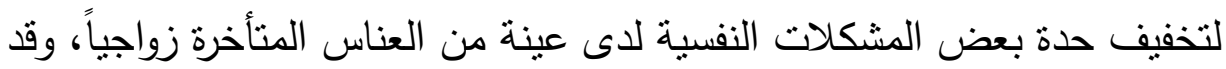
هدفت إلى التعرف على مدى الفروق بين درجات الإنـاث المتأخرات زواجياً

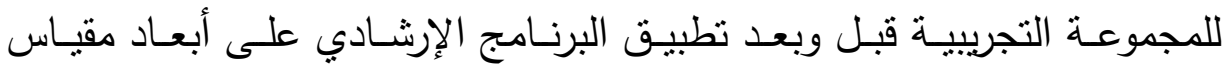

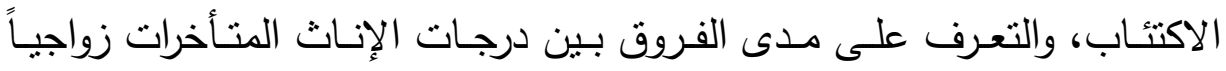
للمجموعة التجريبية في القياسين البعدي والتتبعي على أبعاد مقياس الاكتئاب،

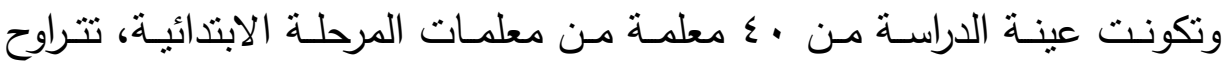

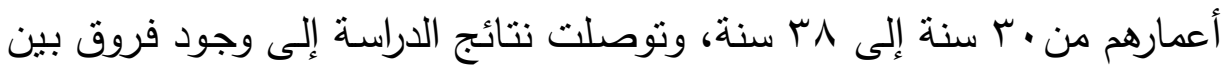

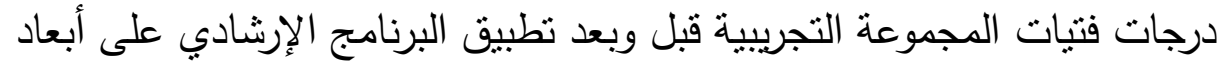

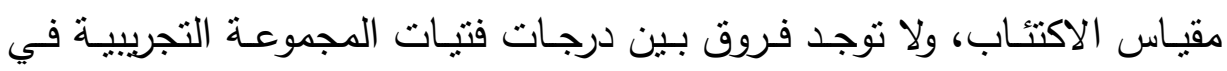
القياسين البعدي والتتبعي على مقياس الاكتئاب.

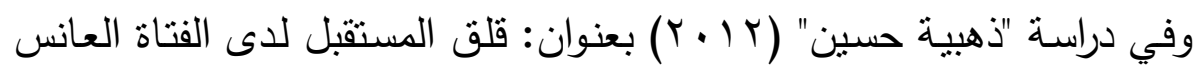
وعلاقته بالتوافق النفسي الاجتماعي، هدفت إلى دارسة آثار العنوسة وانعكاساتها

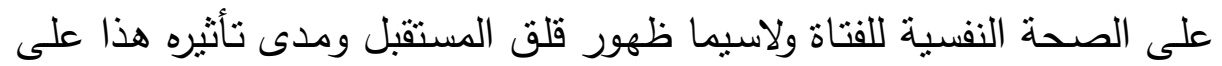
توافقها النفسي و ذللك في ضوء متغيرات السن، والمهنة، والمستوى التعليمي.

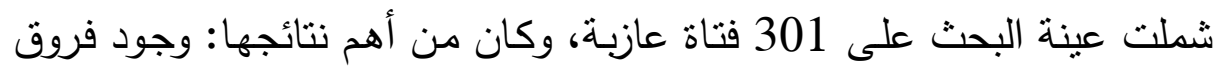
بين درجات الفتيات العوانس على مقياس قلق المستقبل وفقا لمتغير السن، لا توجد فروق بين درجات الفتيات العوانس على مقياس قلق المستقبل وفقا لمتغير المهنة، وجود فروق بين درجات الفتيات العوانس على مقياس قلق المستقبل وفقا لمتغير المستوى التعليمي، وجود فروق بين درجات الفتيات العوانس على مقياس

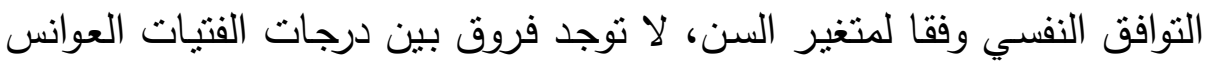
على مقياس التوافق النفسي وفقا لمتغير المهنة، توجد فروق بين درجات الفتيات 
العوانس على مقياس التوافق النفسي وفقا لمتغير المستوى التعليمي، هناك ارتباط سالب ودال بين درجة قلق المستقبل ومستوى التوافق النفسي لدى الفتاة العانس.

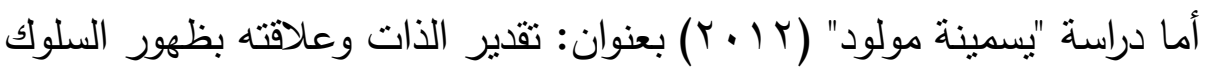

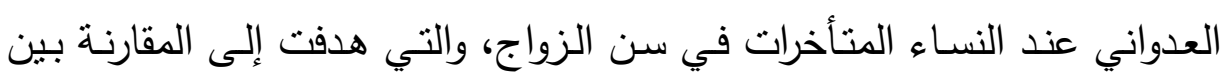

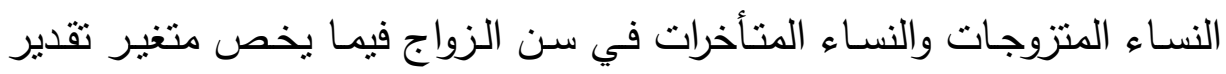

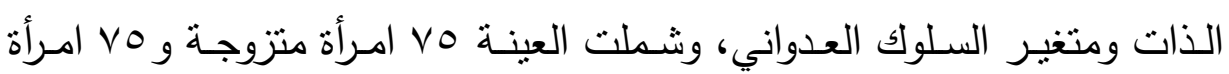
تأخر سن زواجها، وكانت نتائجها على النحو التالي: هناك علاقة بين تأخر سن ونان

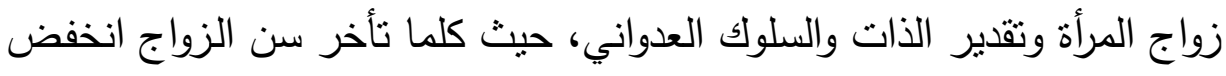
تقديرها لذاتها وبالتالي يظهر السلوك العدواني، لا توجد فروق في درجات تقدير

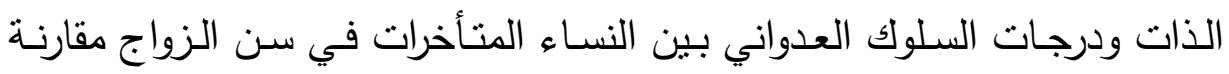
بالنساء المتزوجات. وفي دراسة "جلال السناد" (ب إب) بعنوان: العنوسة مشكلة أم حل دراسة

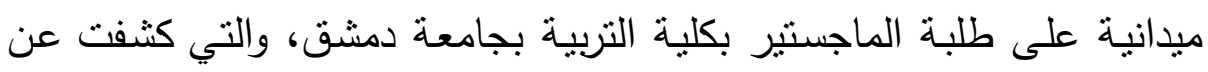
أسباب تأخر سن الزواج كما يراها طلبة الماجستير في كلية التربية بجامعة لئه

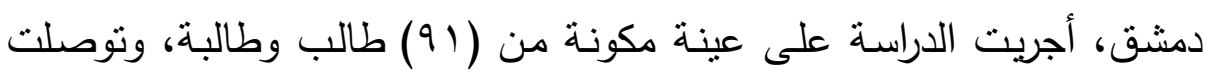

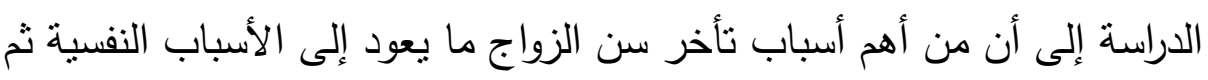

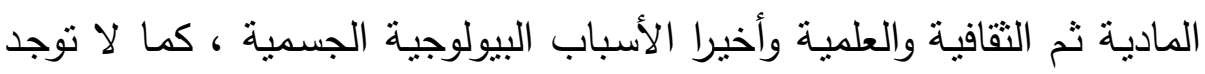
فروق تعزى لمتغير الجنس والجامعة والتخصص.

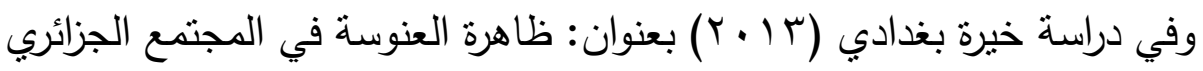
وتأثيرها على المرأة، وقد هدفت الدراسة إلى معرفة الأسباب الحقيقية وراء عنوسة الدية

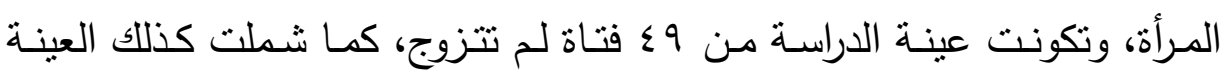

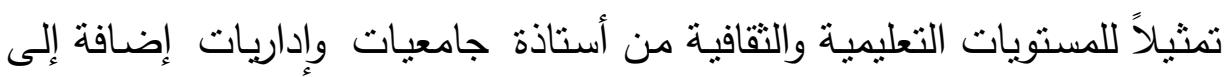

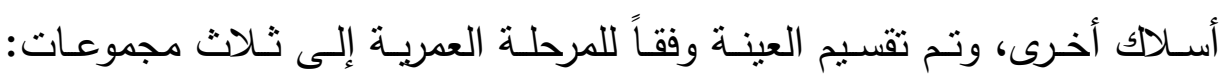

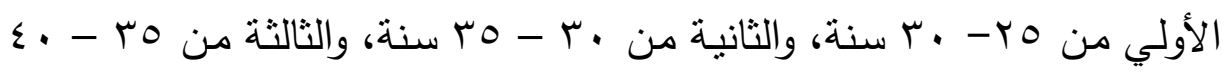
Doi: $10.12816 / 0041722$ 
سنة، ومن أهم النتائج التي وصلت إليها الدراسة أن المرأة هي من اختارت

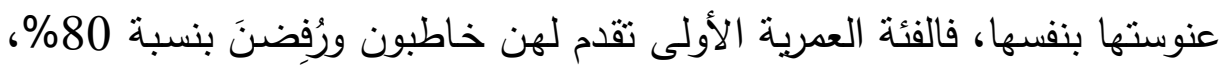
مقابل • r\% لم يتقدم لهن خاطبون، والفئة العمرية الثانية تقدم لهن خاطبون

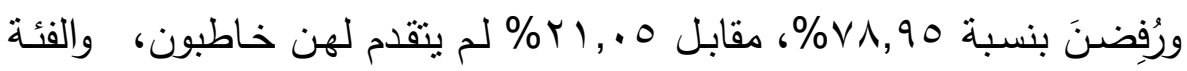

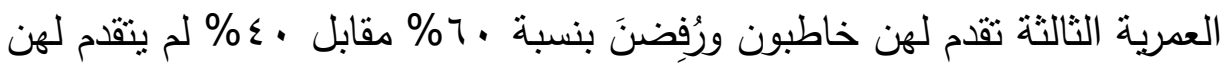
خاطبون. وكانت أسباب الرفض تتلخص في : الثخص الذي تقدم غير مناسب،

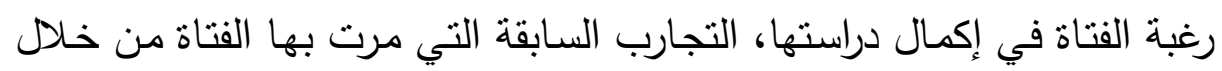
تعرفها على أثخاص وباءت بالفشل. التعقبب على الارراسات السابقة: من خلال عرض الدراسات السابقة نجد أن البحث الحالي اتفق مع العديد من

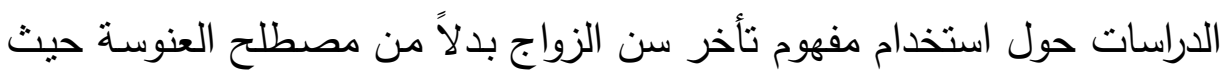

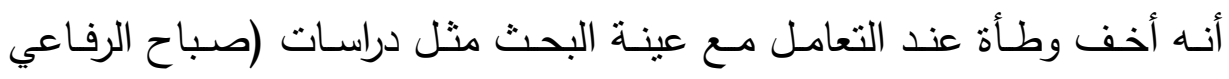

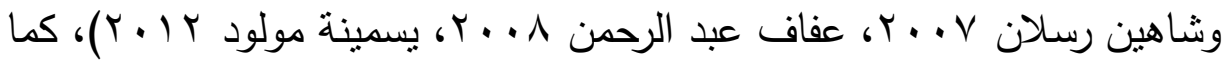

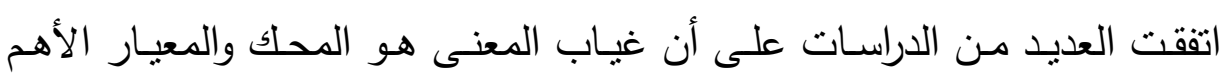

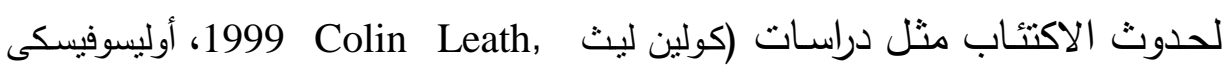
2003 Olesovesky, الدراسات على فعالية العلاج بالمعنى في تخفيف المشكلات النفسية والاجتماعية وكذللك خفض حدة الاكتئاب منل دراسات (سيد عبد العظيم 1997 19 أشرف عبد الحليم

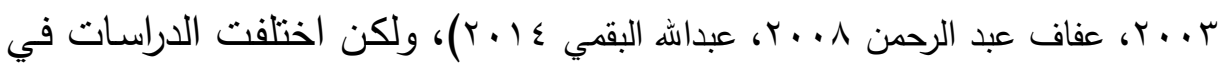

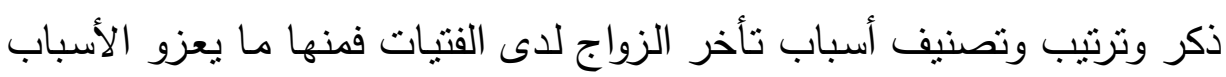

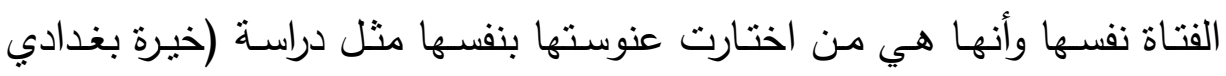
r ا • Y)، ومنها ما يرى أن الأسباب هي نفسية ثم مادية ثم ثقافية وعلمية وأخيراً

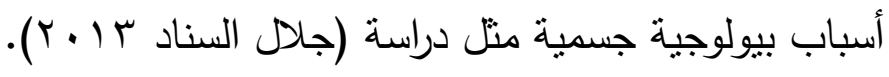


1-توجد فروق ذات دلالة إحصائية بين متوسط رثب درجات معنى الحياة في القياسين القبلي والبعدي لصالح القياس البعدي. ץ-لا توجد فروق ذات دلالة إحصائية بين منوسط رتب درجات معنى الحياة في لئي القياس البعدي والقياس التتبعي. ب-توجد فروق ذات دلالة إحصائية بين متوسط رتب درجات الاكتئاب في القياسين القبلي والبعدي لصالح القياس البعدي.

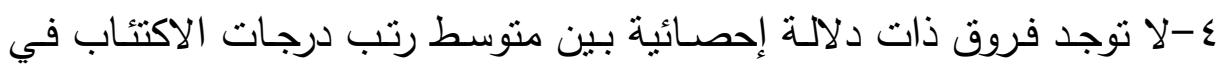
القياس البعدي والقياس التتبعي. - المنهج المستخدم في البحث : قام الباحثان باستخدام المنهج شبه التجريبي

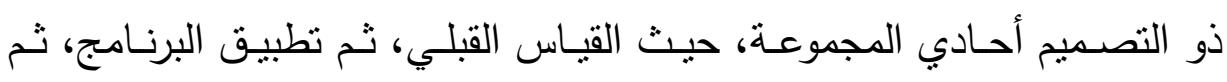

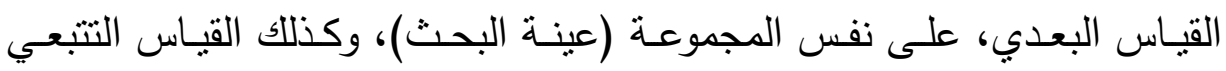
لمتغيرات البحث وبعد مرور فترة المتابعة شهرين من انتهاء البرنامج؛ لمعرفة أثر أثربه التدريب على معنى الحياة في تخفيض الاكتئاب.

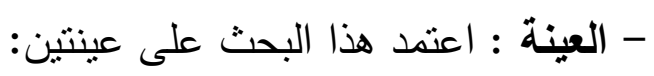

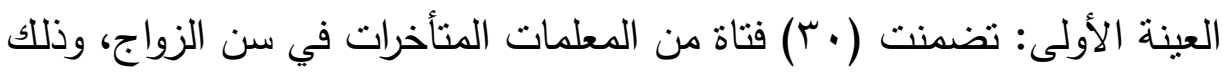

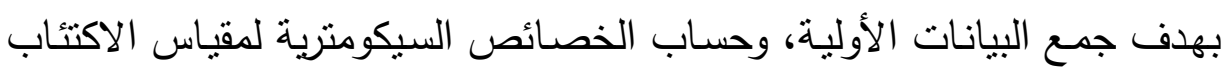

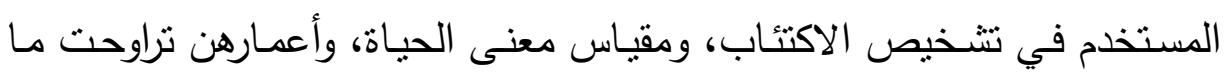
بين (0ب-0 ع ) سنة.

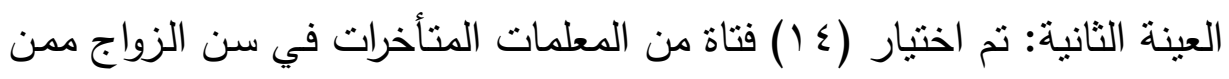
حصلوا على أعلى الدرجات على مقياس الاكتئاب الناتج عن تأخر سن الزواج إن،

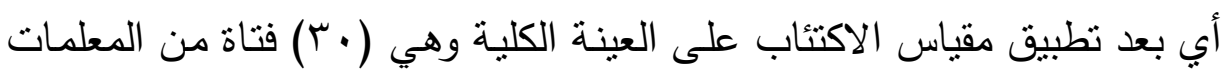

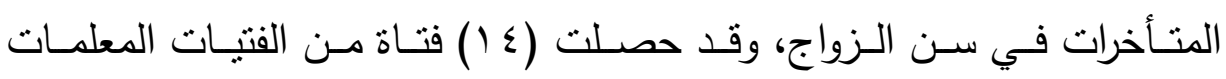
المتأخرات في سن الزواج على درجات أعلى من ( •9) درجة وهن اللاتي يعانين 
من اضطراب الاكتئاب، وحصلوا على أقل الدرجات على مقياس معنى الحياة، أي اقل من (ع (1) درجة وهن اللاتي يعانين من الانخفاض في معني الحياة،

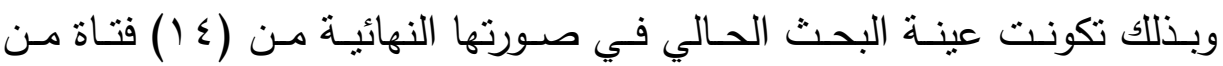
معلمات مرحلة التعليم الأساسي المتأخرات في سن الزواج بمحافظة كفر الشيخ

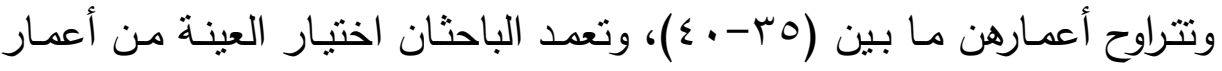

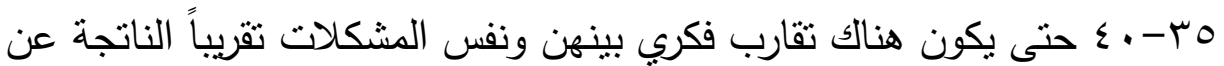

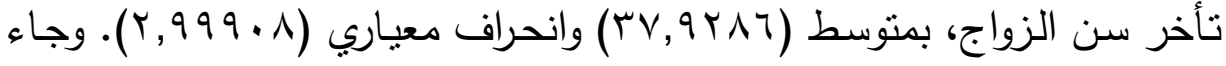
وصف العينة لمعني الحياة والاكتئاب في القياس القبلي كما في الجدول التالي: جدول (1) وصف عينة البحث على متغير العمر ومعنى العياة والاكتئاب

$$
\text { ( } 1 \varepsilon=\dot{0})
$$

\begin{tabular}{|c|c|c|c|c|}
\hline الانحراف المعياري & المتوسط & اصغر درجة & اكبر درجة & المتغير \\
\hline$r, 999.1$ & 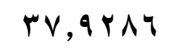 & $\mu_{0, \ldots}$ & $\varepsilon \cdot, \cdots$ & العمر \\
\hline 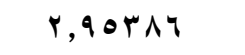 & 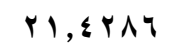 & $1 \wedge, \cdots$ & $r v, \ldots$ & القبول والرضا \\
\hline r,rq৭q & $19, r \wedge \odot V$ & $i v, \ldots$ & $r \varepsilon, \ldots$ & الهذف من الحياة \\
\hline r,YAYYA & $|v, \wedge \odot \vee|$ & $10, \ldots$ & $r r, \ldots$ & المسئولية \\
\hline I, rArvA & $1 \varepsilon, r \wedge \odot V$ & Ir, . & $i v, \ldots$ & التسامي بالذات \\
\hline$\checkmark, \wedge q Y \backslash r$ & $V Y, \wedge \circ V I$ & $70, \ldots$ & $\wedge \wedge, \ldots$ & الارجة الكلية لمعنى \\
\hline$\varepsilon, 7 \leq r q 1$ & $111, r 1 \leq r$ & $1,1, \ldots$ & $119, \ldots$ & الاكتئاب \\
\hline
\end{tabular}

1. مقياس معني الحياة إعداد/ محمد حسن محمد الأبيض ( • ( ب):

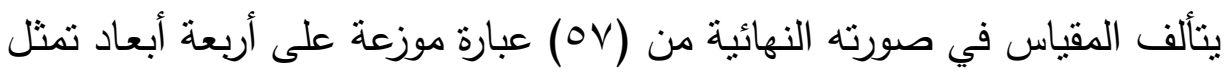

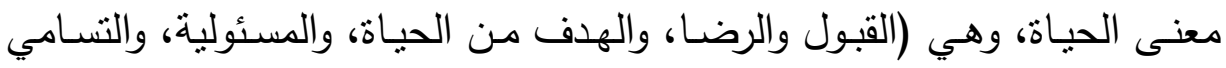
بالذات) ويشمل على ( إ) عبارة موجبة، و (7 (1) عبارة سالبة، وتم تصميم شكل

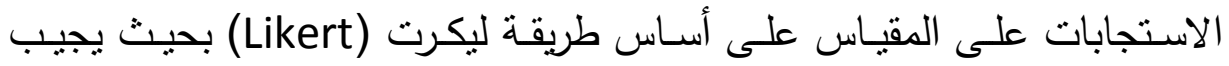

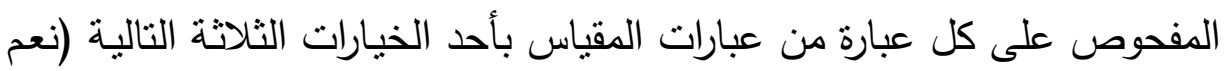


- أحياناً - لا) حيث تحصل الاستجابة الأولى على ثلاثة درجات، والثانية على

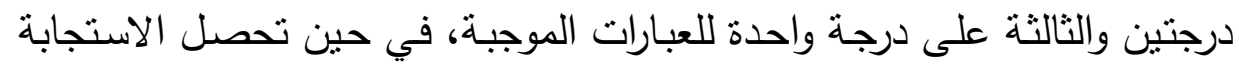
الأولى على درجة واحدة والثانية على درجتين والثالثة على ثلاثة درجات للعبارات

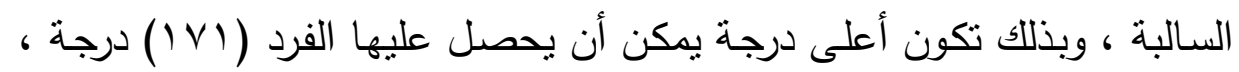

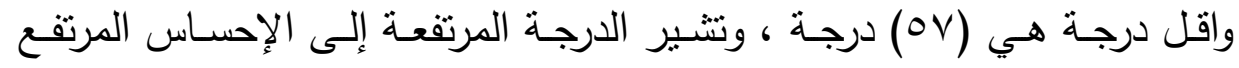

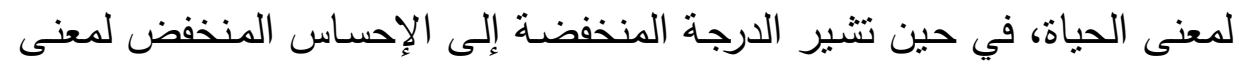
الحياة.

الكفاعة السبكومتريه للمقياس

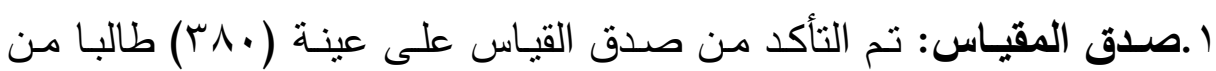
طلاب الجامعة وذلك عن طريق عن طريق:

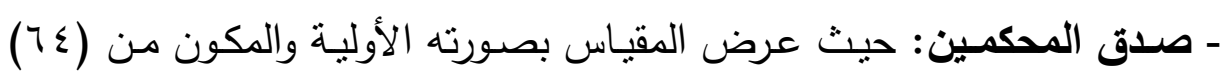

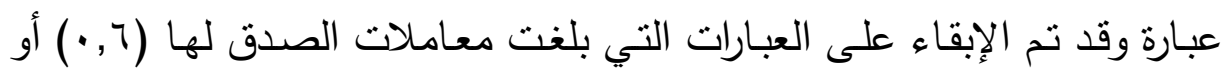

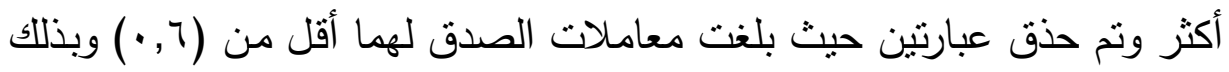
أصبح المقياس (r آT) عبارة. - صدق الاتسـاق الداخلي: حيث قام الباحث بإيجاد التجانس الداخلي للمقياس

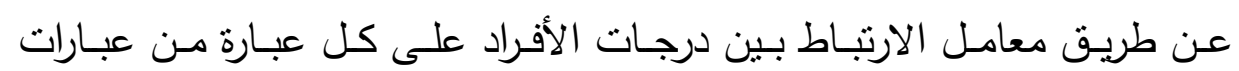

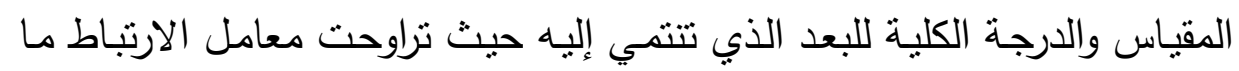

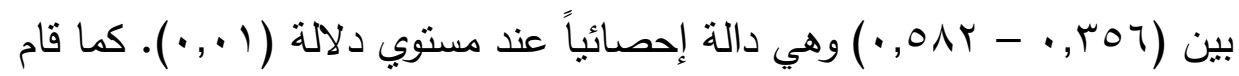

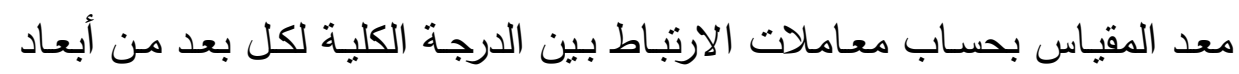

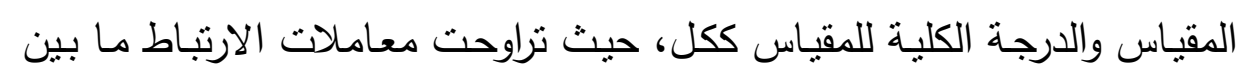

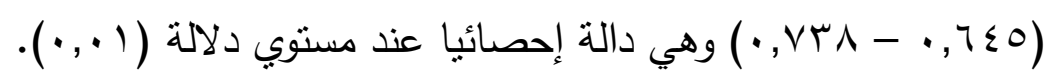

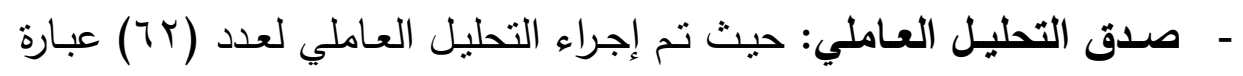

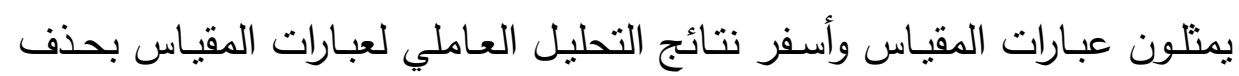


(0) عبارات لأنها لم تتشبع على أي من العوامل الأخرى. وبذلك أصبح عدد عبارات المقياس (ov) عبارة. r. ثبات المقياس: استخدم معد المقياس لحساب الثبات طريقة ألفا - كرونباخ، وطريقة إعادة تطبيق المقياس بفاصل زمني قدرة أسبوعين بين التطبيق الأول

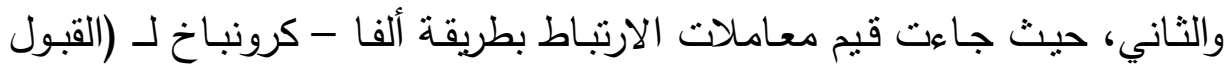

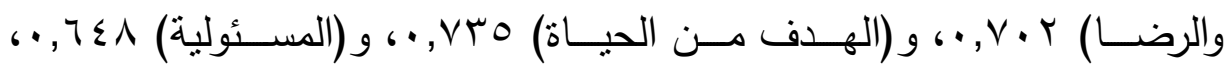

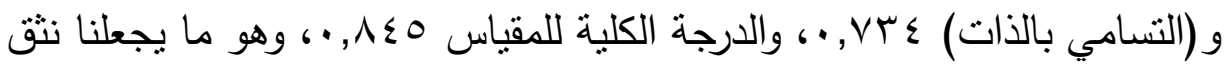
في ثبات مقياس معنى الحياة.

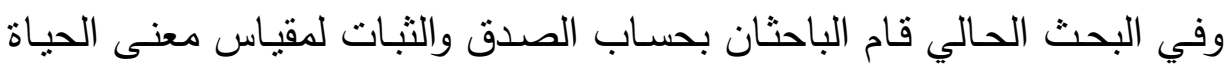

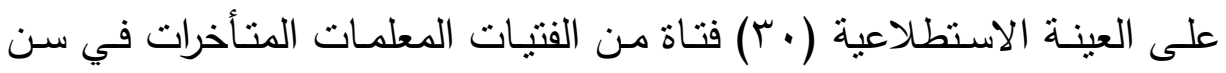
الزواج. ففي حساب الصدق استخدم الصدق المرتبط بالدحكات حيث تمت مقارنة درجات المقياس بدرجات مقياس معنى الحياة إعداد/ عبدالرحمن سليمان، إيمان

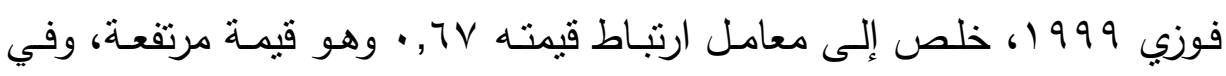
حساب الثبات استخدم الباحثان الطرق التالية:

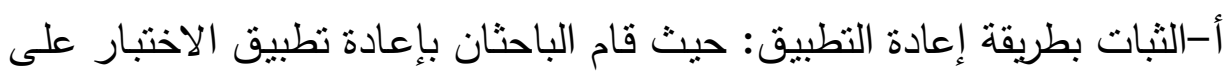

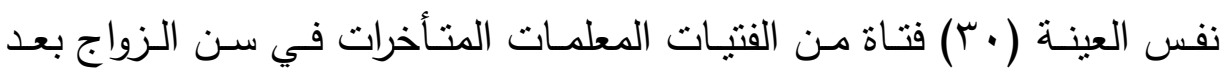

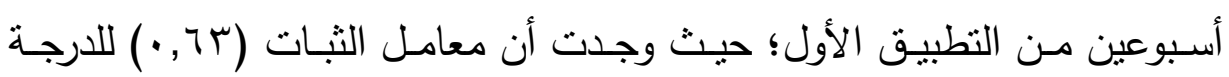
الكلية للمقياس، وهي قيمة مرتفعة ودالة إحصائياً. ب - الثبات بمعادلة ألفا-كرونباخ: حيث حصل الباحثان على معلى معامل ثبات قدرة آTV , · وهو دال بما يكفي للثقة في ثبات المقياس •

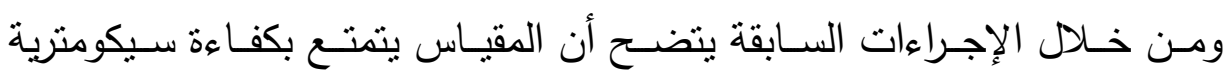
مرتفعة. r. مقياس الاكتئاب للفتيات المتأخرات في سن الزواج: (إعداد/ الباحثان) 
هدف المقياس: تحديد درجة الاكتئاب لاى الفتيات المعلمات المتأخرات في سن الزواج. وصف المقياس: يتكون مقياس الاكتئاب من (0؛) عبارة تقيس جميعها الاكتئاب

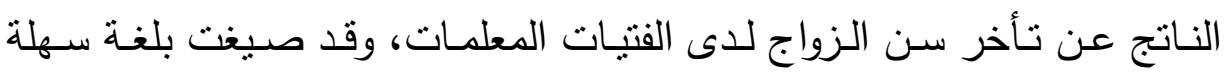
وواضحة، وتعليمات الاختبار يطلب اختيار إجابة واحدة من ثلاثة إجابات وهي

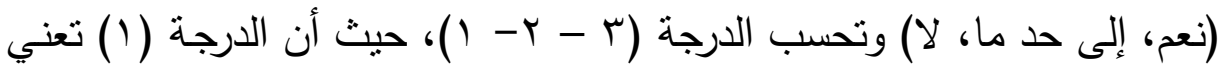

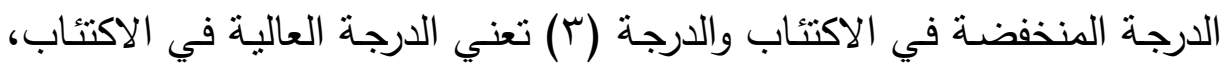

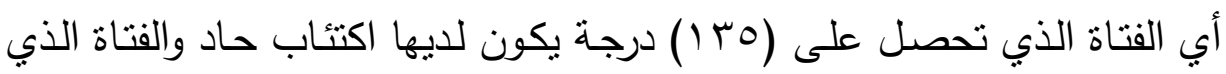
تحصل على درجة (0؛ ) يكون لايها اكتئاب خفيف. مراحل بناء المقياس: بعد الاطلاع على أدبيات ودراسات سـابقة لمعني الحياة

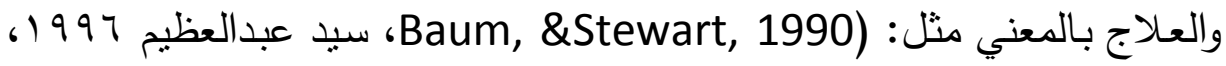

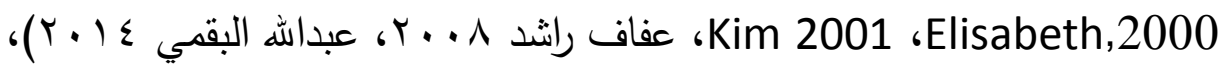

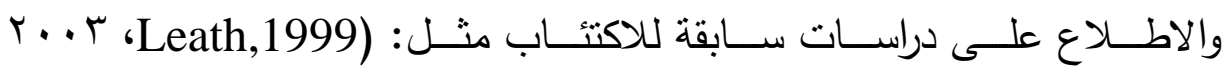

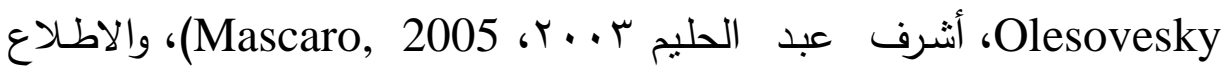
على دراسات سابقة للمتأخرات في سن الزواج مثل: (صباح الرفاعي وشاهين

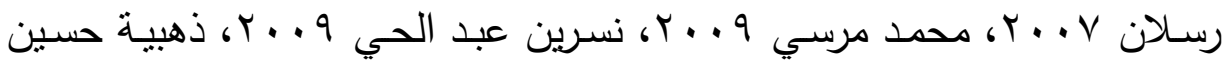

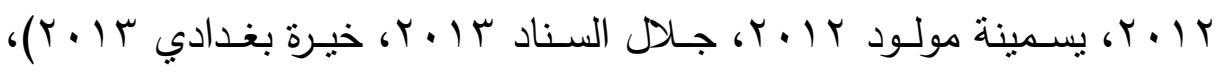
توصل الباحثنان إلى تصميم مقياس الاكتئاب للفتيات المتأخرات في سن الزواج

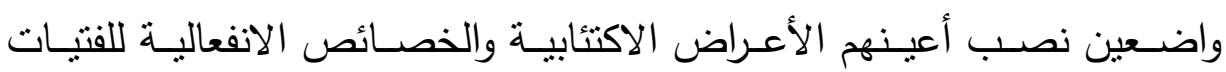
المتأخرات في سن الزواج، ومنها:-

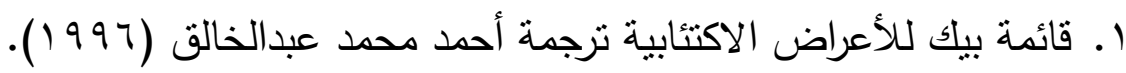

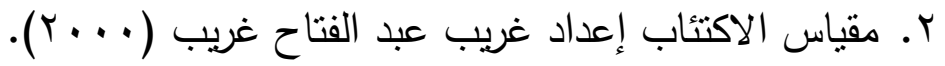

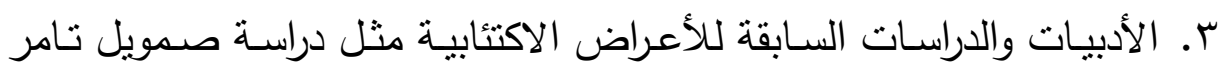

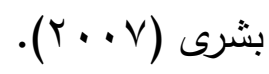

Doi: $10.12816 / 0041722$ 


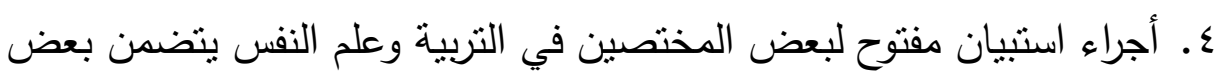

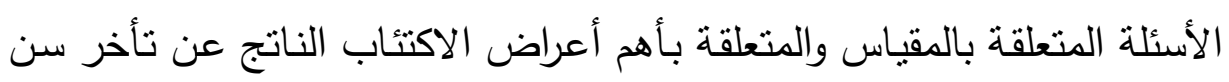

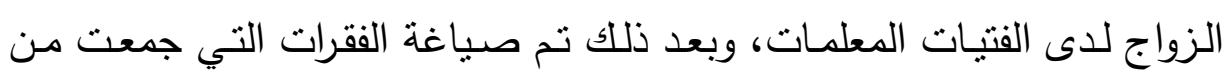
الإجراءات السابقة بصورة تتسم بالسهولة والوضوح والدقة في التعبير عن مفهوم الاكتئاب النفسي، ثم عرض المقياس بفقراته على مجموعة من الأساتذة أعضاء هيئة التدريس المتخصصين. حساب الكفاءة السيكومترية للمقياس:

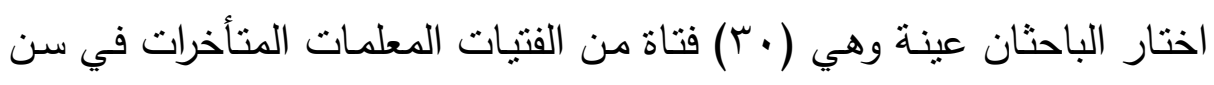

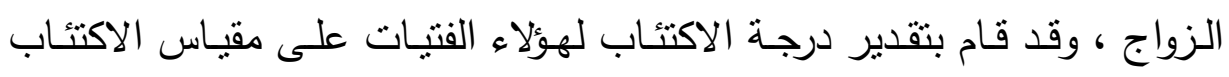
للفتيات المتأخرات في سن الزواج.

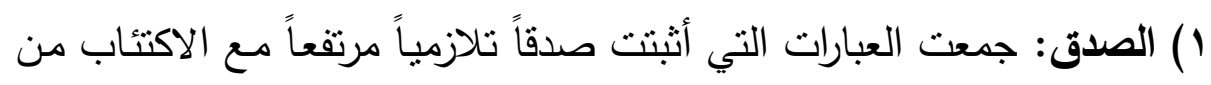
دليل تشخيص رابطة الأطباء النفسين في الولايات المتحدة الأمريكية (9Av ( ))،

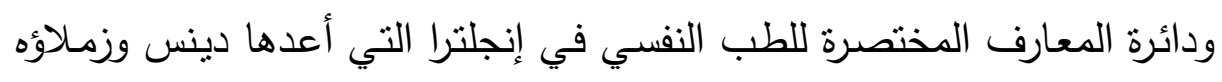

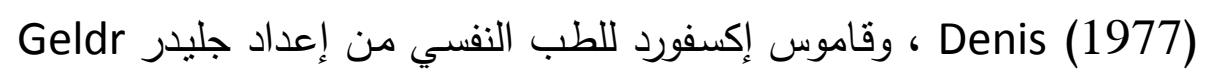

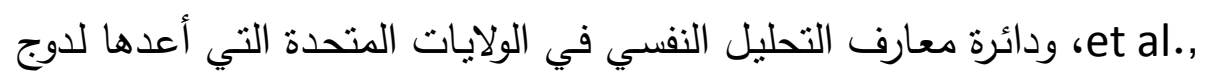

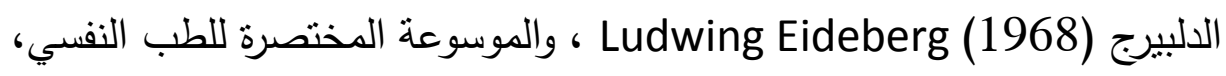

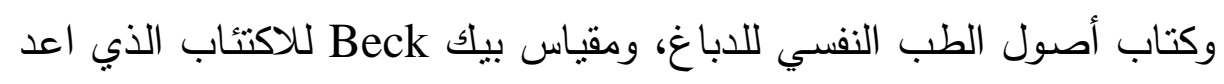

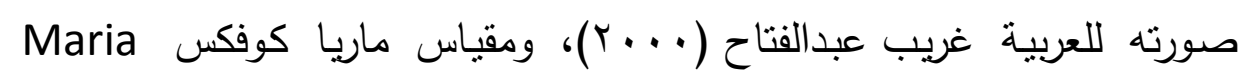

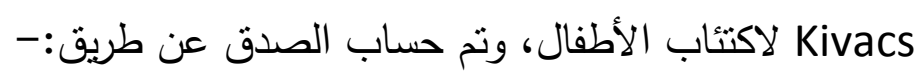

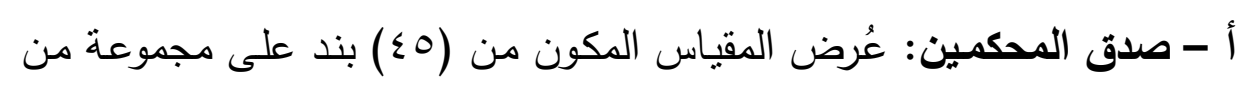

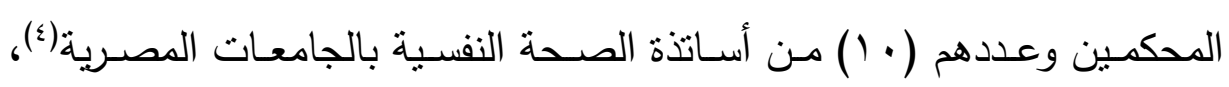


وحدد الباحثان معامل الاتفاق •^^\% فأكثر، وقد تم تعديل العبارات التي لم تحظ

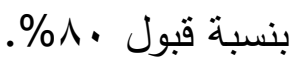

ب - صدق المحك: حُسب معامل الارتباط بين المقياس الحالي ومقياس الاكتئاب

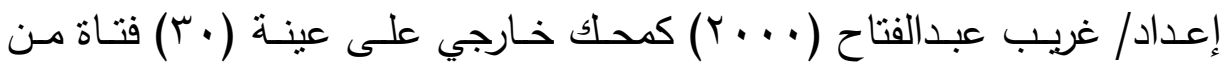
الفتيات المعلمات المتأخرات في سن الزواج، وخلص إلى معامل الارتباط قدره

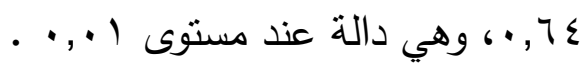

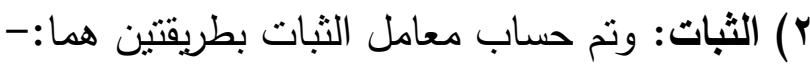

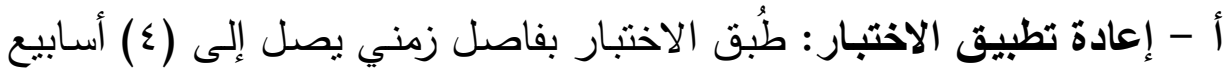

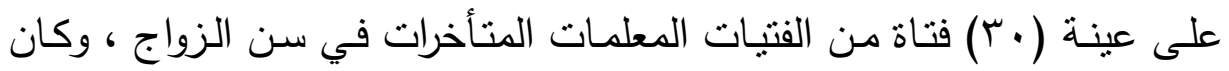
معامل الارتباط VY, VY, •، وهي قيمة مرتفعة. ب- حساب التجزئة النصفية: حُسب الثبات عن طريق التجائهئة النصفية، حيث

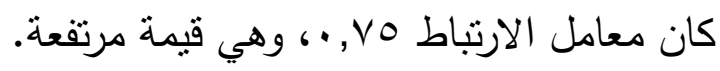

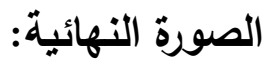

(0) عبارة تقيس الاكتئاب الناتج عن تأخر سن الزواج، وتجيب المعلمة على

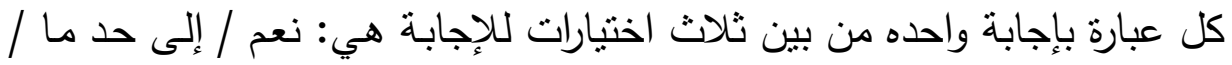

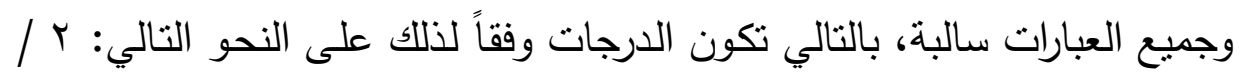

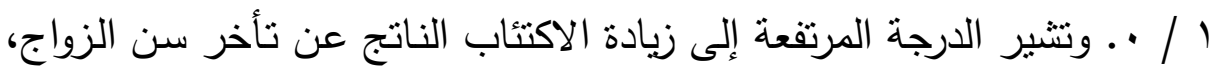
والعكس صحيح.

\section{برنامج قائم علي فنيات العلاج بالمعني: (إعداد/ الباحثان)}

مصادر البرنامج: تم إعداد هذا البرنامج من خلال الاستعانة بالدراسات النفسية

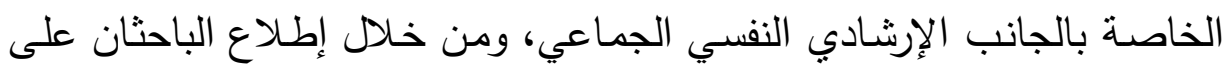

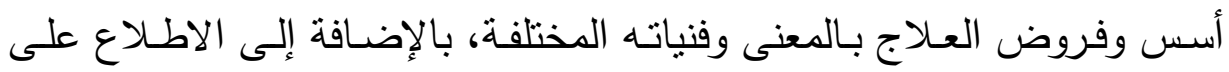
البحوث والدراسات السابقة التي نتاولت العلاج بالمعنى. 
أهداف البرنامج: تتمنل أهداف البرنامج فيما يلي:-

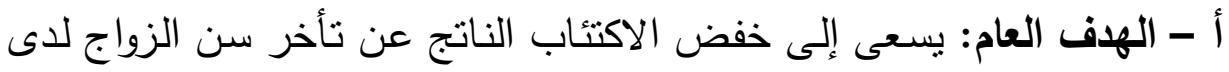

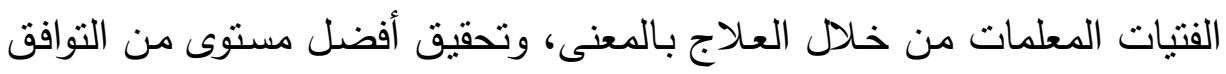

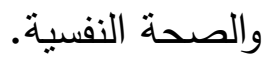

ب - الأهداف الخاصة: يهدف هذا البرنامج إلى تحقيق الأهداف التالية:

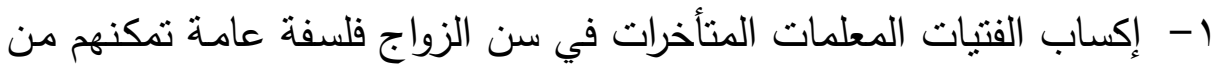
التعامل مع ضغوط الحياة، دون إحباط أو اكتئاب. r- بمساعدة الفنتات على التظلب على مشكلة ارتفاع الاكتئاب. r- r- مساعدة الفنتات على إيجاد معنى وهدف لحياتهم.

ع- - مساعدة الفنتات على إقامة علاقات اجتماعية ايجابية مع المحيطين بهم. 0- تدريب الفتيات على تطبيق وكيفية الاستفادة من فنيات البرنامج في حياتها بعد انتهاء البرنامج، خشية تعرضهم لأية انتكاسة.

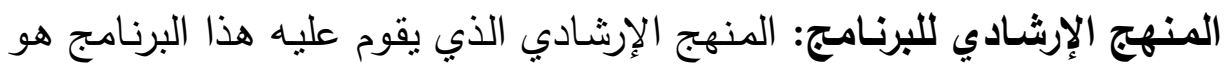

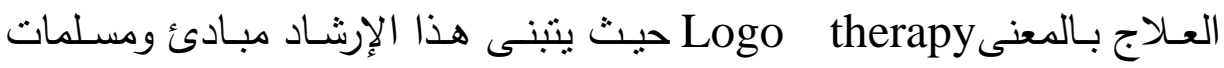
وفنيات العلاج بالمعنى. المستفيدون من البرنامج: المستفيدون من البرنامج الفتيات المعلمات المتأخرات

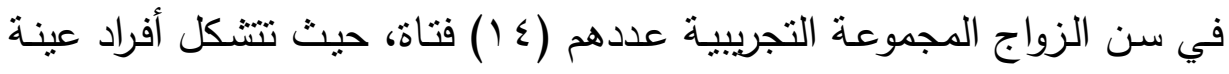

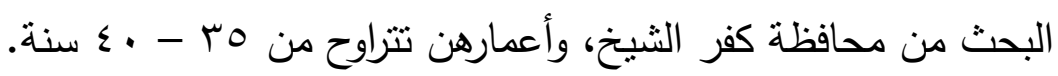

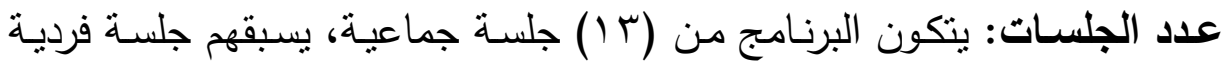

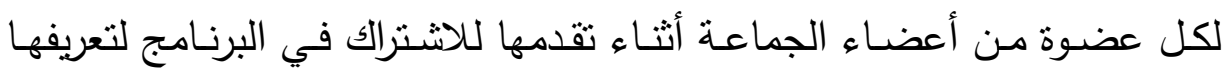

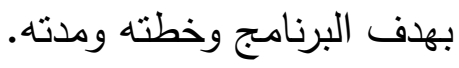

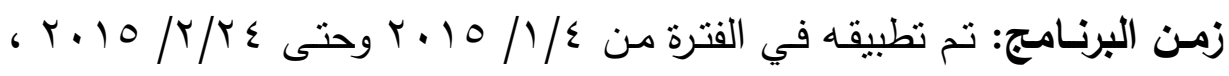

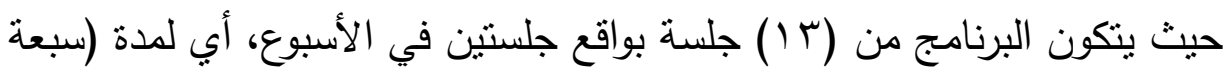

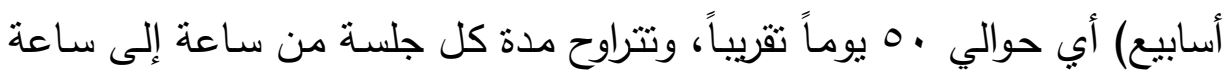


ونصف لكل جلسة، وفي نهاية البرنامج طُبق مقياس الاكتئاب الناتج عن نأخر

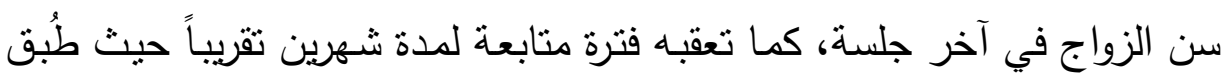
القياس التتبعي. مكان التطبيق: يقام البرنامج في دار رعايـة الفتبات بالثـئون الاجتماعية بكفر الثيخ حيث يسهل تواجد المجموعة التجريبية. فنيات البرنامج: يستخدم الباحثان فنيات العلاج بالمعنى، وهذه الفنيات:-

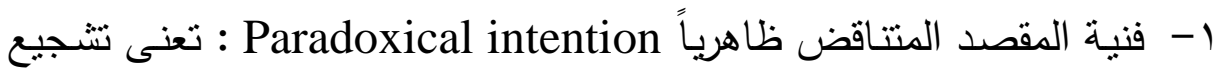
المريض على أن يفعل أو يرغب في حدوث الأشياء التي يخافها بالذات، حيث تعتمد هذه الفنية على فكرة مواجهة القلق المتوقع.

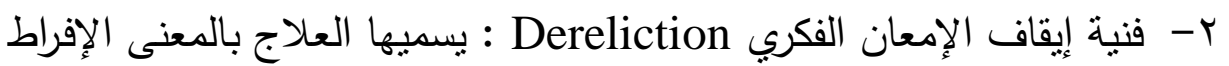
في التفكير، والمريض الذي يقع في ظـاهرة الإفراط في التفكير يقع في دائرة مغلقة، وهى أن الإفراط في التفكير يؤدى إلى الإفراط في القصد، والإقراط في القصد يؤدى إلى الإفراط في التفكير، والإفراط في التفكير يؤدى إلى مشـاكل الإسل

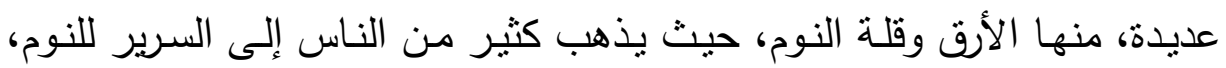

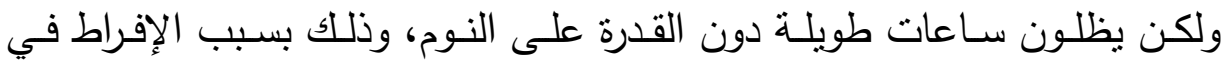

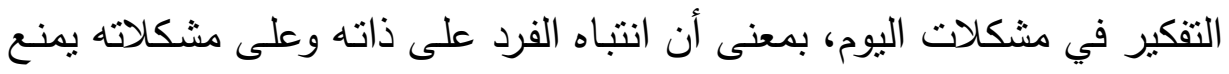

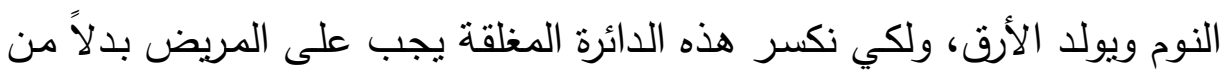
أن يلاحظ ويشاهد ويركز على ذاته أن بتتاسى ذاته ويتمتع بالتلقائية. ولكي يواجه

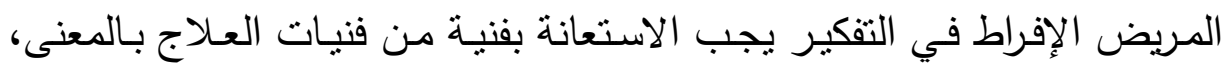

وهى إيقاف الإمعان الفكري. (Frankl, 1978: 152) r- المسرحيات النفسية القائعة على المعنى Logo drama : استخدم فرانكل هذه الفنية للتعامل مع بعض المرضى، منهم حالة أم لطفلين أحدهما معافى سليم والآخر معاق، وقد مات ابنها السليم، ولذللك تمردت على قدرها وحاولت الانتحار مـع الولا الكسيح، ولكنه رفض، وقد أجرى فرانكل معها حوارًا حاول من خلاله. Doi: 10.12816/0041722 
استخدام التحليل وجعلها تشعر بمعنى معاناتها مع ولدها الكسيح، وكيف أن هذا الولا هو الذي يعطي لحياتها معنى، وقد انفجرت هذه السيدة في البكاء، وأقرت

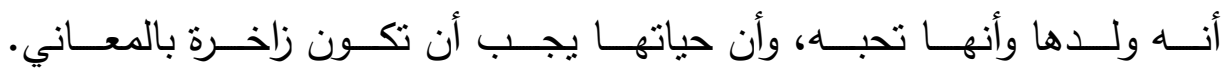

(Frankl, 1978: 35)

ع- فنية القصة الرمزية Parable method : يشير فرانكل إلى هذا الأسلوب

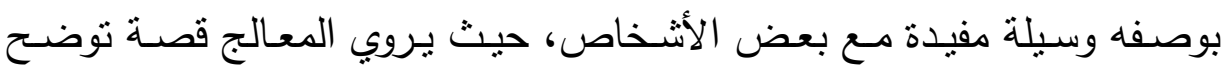

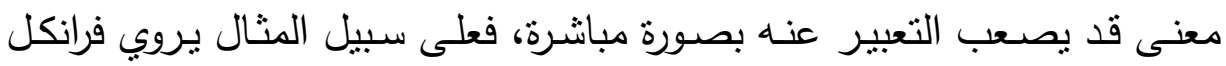

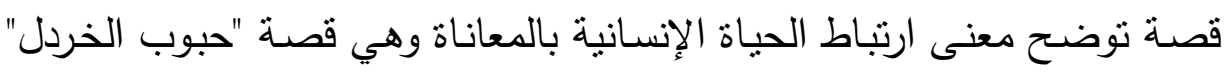

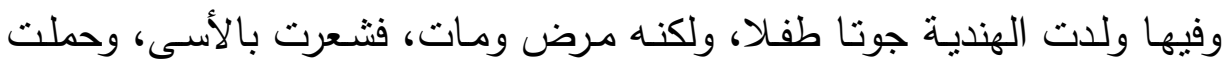

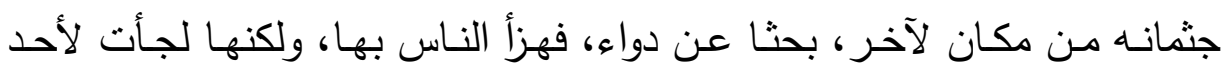

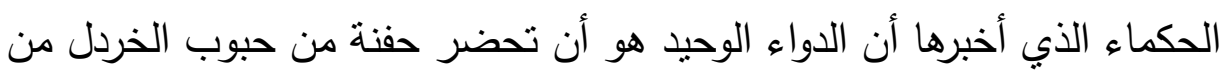

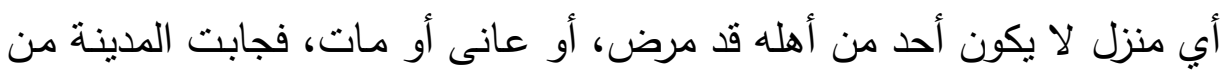

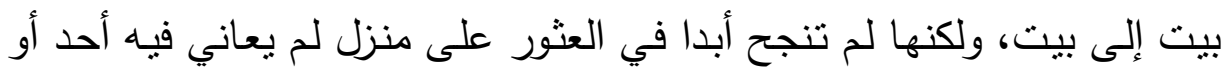

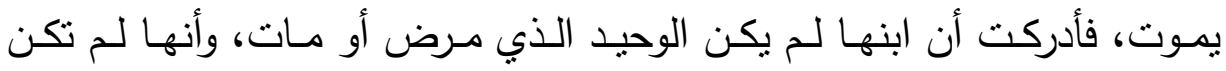

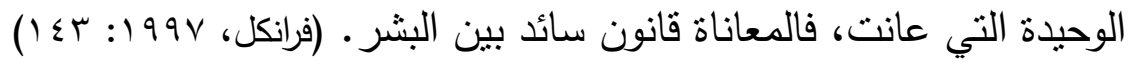
ه- الحوار السقراطي The Socratic dialogue: أسلوب في العلاج بالمعنى يستخدم مع المريض من أجل استتارة المعنى لديه، وذلك عن طريق توجيه أسئلة استفزازية Provocative question في إطـار حوار تسـاؤلي. (صـلاح فؤاد، (1). :199V

צ- فنية فصل الذات Self-distancing technique : تقوم هذه الفنية على أساس من عقيدة العلاج بالمعنى بالقدرة على الاستقلال بالذات كخاصية إنسانية،

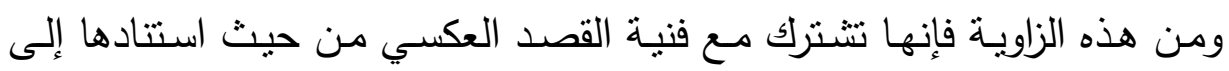

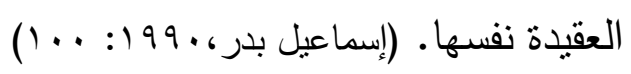

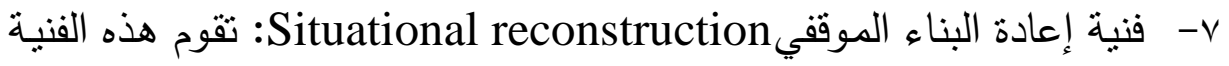
على التخيل وتستخدم مـع المرضسى الذين يعانون من أحداث ضـاغطة، حيث 
يطلب من المريض أن يتخيل ثلاث حالات كان من المكن أن تأتي أسوأ من

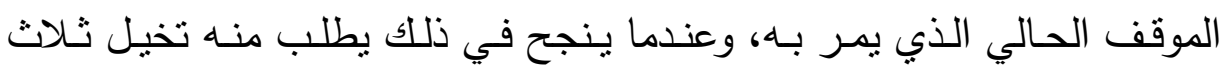
حالات أقل سوءا من الموقف الذي يمر به وبعد أن يقوم المريض بذائلك، ويكون

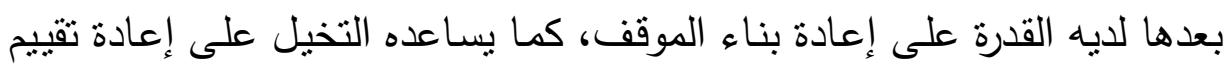

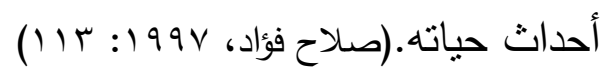

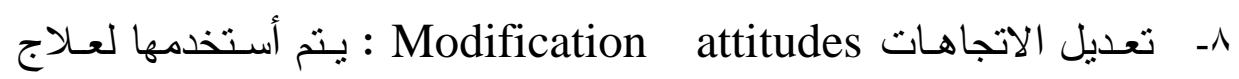
العصابية الوجودية؛ حيث إن العصاب الوجودي نشأ في الحالات التي يفقد فيها

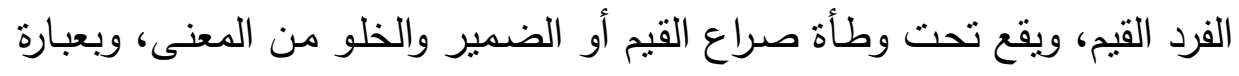

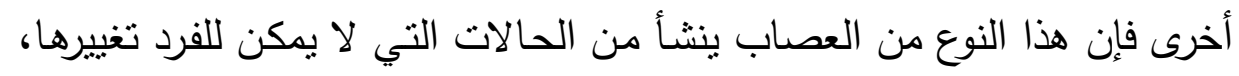

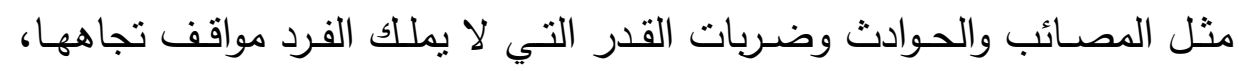

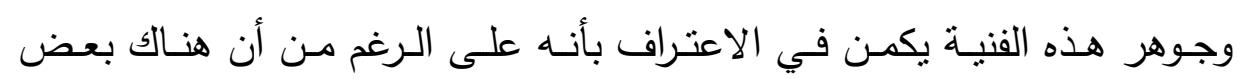

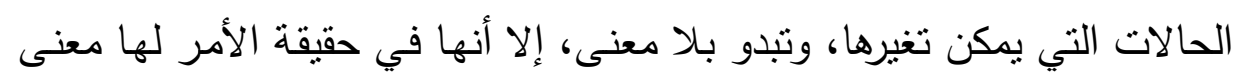

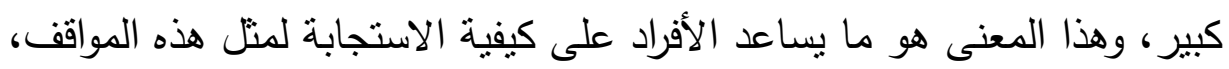

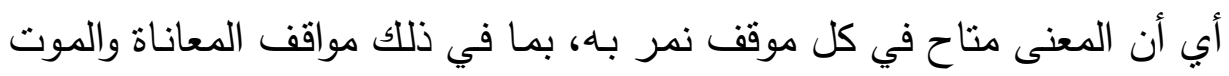
(Marshall, 2009: 81)

الصعويات التي واجهة الباحثان أثناء التطبيق: وجود نوع من الغيرة وعدم

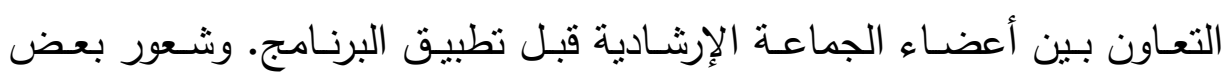

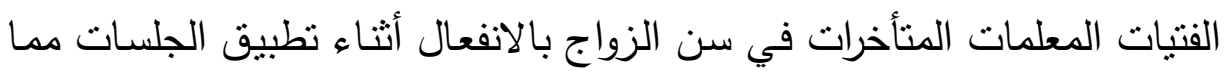

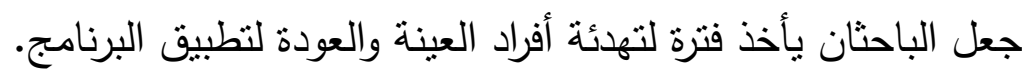

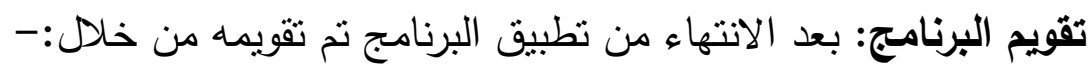

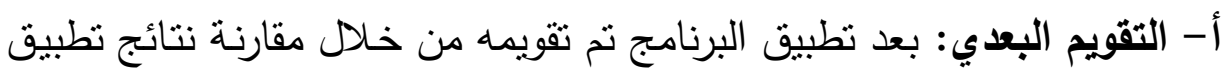

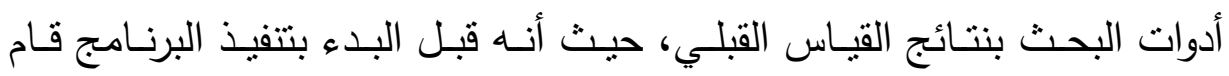

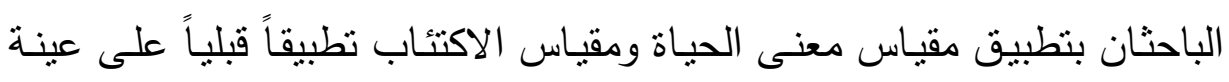

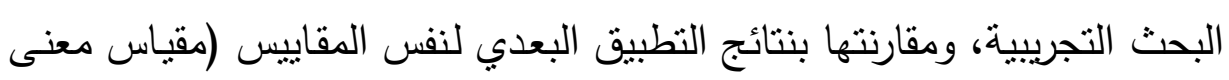


الحيـاة ومقياس الاكتئاب) بعد تطبيـق البرنـامج علي المجموعـة التجريبيـة مـن الفتيات المعلمات المتأخرات في سن الزواج للتعرف علي مدي فعالية برنامج قائم

على العلاج بالمعنى علي أفراد العينة. ب- التقويم التتبعي: بعد مرور شهر تقريبا من التقويم البعدي، تم تطبيق مقاييس

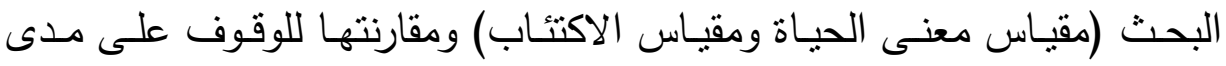

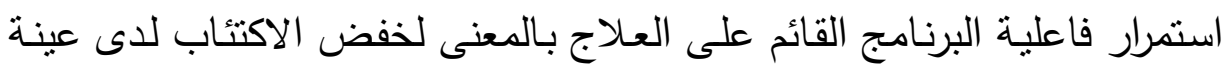

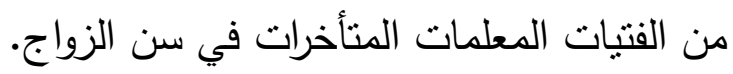
رابعاً: الخطوات الإجرائية للاراسـة:

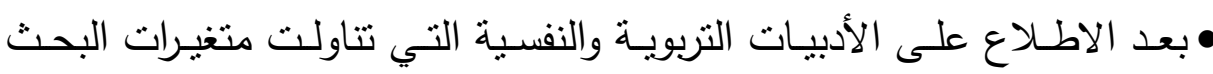

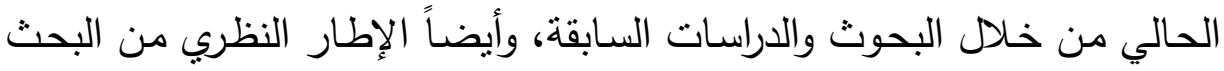
الحالي بغرض الإفادة منها في بناء البرنامج القائم على العلاج بالمعنى وإعداد الإطار النظري الخاص بالمتأخرات في سن الزواج ومتغيرات البحث.

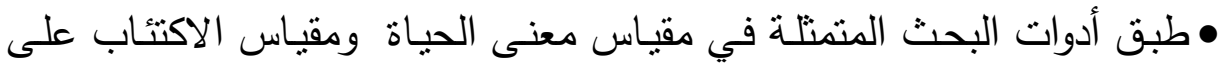
المتأخرات في سن الزواج ، لتقنين المقاييس على مجموعة البحث التجريبية التي تتلقي البرنامج القائم على العلاج بالمعنى فيما بعد.

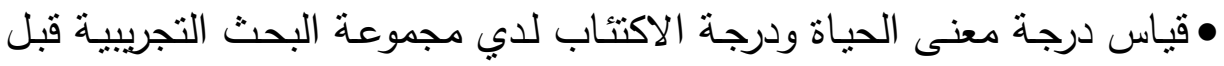
تطبيق البرنامج القائم على العلاج بالمعنى ، وهو ما يسمي بالقياس القبلي لعينـة البحث. •وبعد ذلك طبق الباحثان البرنامج القائم على العـلاج بـالمعنى على مجموعـة البحث التجريبية. •قياس درجة معنى الحياة ودرجة الاكتئاب لدي مجموعة البحث التجريبية بعد تطبيق البرنامج القائم على العلاج بالمعنى، وهو ما يسمى بالقياس البعدي لعينة البحث. 
فعالية برنامج إرشادى قائم على العلاج بالمغنى لخفض الاكتئاب الناتج عن تأخر سن الزواج لدى المعلمات

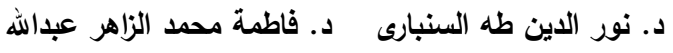

•وبعد مرور فترة زمنيه شهرين من تطبيق البرنامج القائم على العلاج بالمعنى،

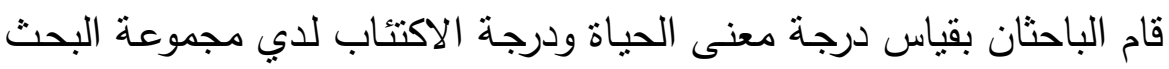
التجريبية، وهو ما يسمي بالقياس التتبعي.

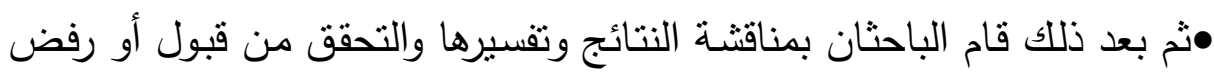
فروض البحث.

•وقدم الباحثنان بعض التوصيات والمقترحات التربوية في ضوء ما أسفرت عنه

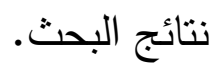

\section{خامساً: الأساليب الإحصائية المستخدمة}

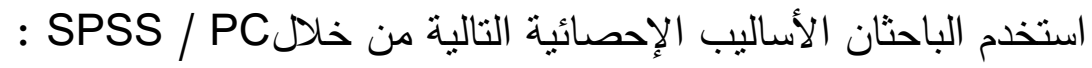

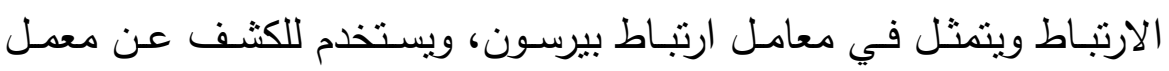

الارتباط في التحقق من الصدق والثبات لأدوات البحث.

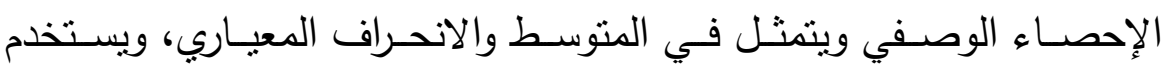
للكثف عن مدى التباين بين أفراد العينة.

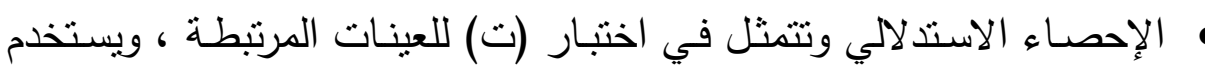
للكثف عن الفروق بين أفراد العينة. 


\section{نتائج البحث:}

• نتائج الفرض الأول: ينص على انه "توجد فروق ذات دلالة إحصائية بين

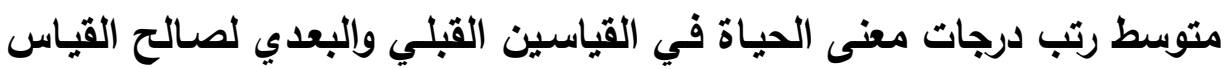
البعدي". ولاختبار صحة هذا الفرض حسب متوسطي درجات الفتيات باستخدام أسلوب

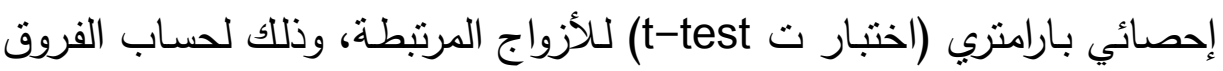
بين منوسطي درجات مجموعة البحث في القياسين القبلي والبعدي على مقياس بلى بلى

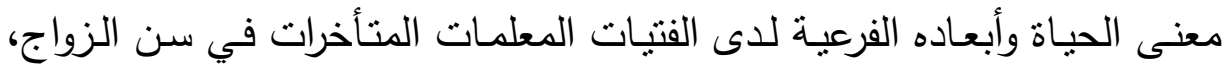
ويتضح ذلك في الجدول التالي:

جدول (r) اتجاه فروق متوسطي درجات مجموعة البحث في القياسين القبلي والبعدي على مقياس معنى الحياة وأبعاده الفرعية (ن= \& 1)

\begin{tabular}{|c|c|c|c|c|c|c|}
\hline مستوى الدلالة & قيمة "ت" & درجة حرية & الانحراف المعياري & المتوسط & القياس & مغنى الحياة \\
\hline \multirow{2}{*}{$\cdot, \cdot 1$} & \multirow{2}{*}{$11, \leqslant 17$} & \multirow{2}{*}{ ir } & r,qorkt & 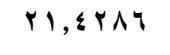 & القبلي & \multirow{2}{*}{ القبول والرضا } \\
\hline & & & צוצדצ & $r r, v \wedge \odot v$ & البعدي & \\
\hline \multirow{2}{*}{$\cdot, \cdot 1$} & \multirow{2}{*}{$r v, .19$} & \multirow{2}{*}{ ir } & r., & $19, r \wedge O V$ & القبلي & \multirow{2}{*}{ الهدف من الحياة } \\
\hline & & & Y,0Y.YY & r^,r॰V & البعدي & \\
\hline \multirow{2}{*}{$\cdot, \cdot 1$} & \multirow{2}{*}{$r q, 1.1$} & \multirow{2}{*}{ ir } & r,YAYYA & $|v, \wedge \odot \vee|$ & القبلي & \multirow{2}{*}{ المسئولية } \\
\hline & & & $1, r$ IVYr & rч, . . & البعدي & \\
\hline \multirow{2}{*}{$\cdot,+1$} & \multirow{2}{*}{ lA,rqY } & \multirow{2}{*}{ ir } & I,rArVA & $1 \leqslant, Y \wedge \circ V$ & القبلي & \multirow{2}{*}{ التسامي بالذات } \\
\hline & & & 1,97117 & $r r, \ldots$ & البعدي & \\
\hline \multirow{2}{*}{$\cdot, \cdot 1$} & \multirow{2}{*}{ rч,v৭1 } & \multirow{2}{*}{ ir } & V,AqYIr & $V Y, \wedge \circ V I$ & القبلي & \multirow{2}{*}{ الارجة الكلية } \\
\hline & & & $\vee, r \neg \vee \wedge \wedge$ & $11 \cdot, 1 \leq r q$ & البعدي & \\
\hline
\end{tabular}


فعالية برنامج إرشادى قائم على العلاج بالمغنى لخفض الاكتئاب الناتج عن تأخر سن الزواج لدى المعلمات

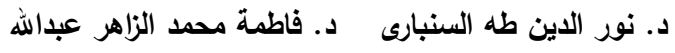

يتضـح مـن الجدول (Y) أن قيمـة (ت) المحسوبة لأبعـاد مقيـاس معنى الحيـاة

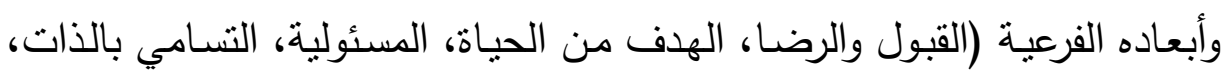

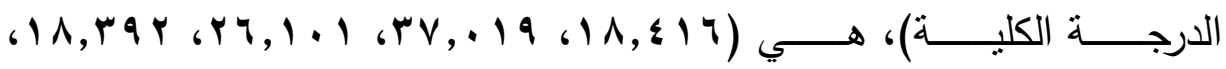


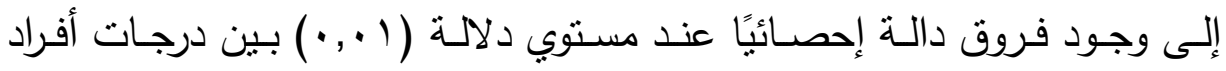
مجموعة البحث قبل وبعد تطبيق البرنامج القائم على فنبات العلاج بالمعني علي مقياس معنى الحياة لصالح القياس البعدي، وبذلك يتم قبول الفرض الموجه.

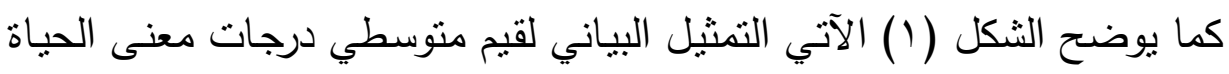
(القبول والرضـا، الهدف من الحياة، المسئولية، التسامي بالذات، الدرجة الكلية) لمجموعة البحث في القياسين القبلي والبعدي لصالح القياس البعدي.
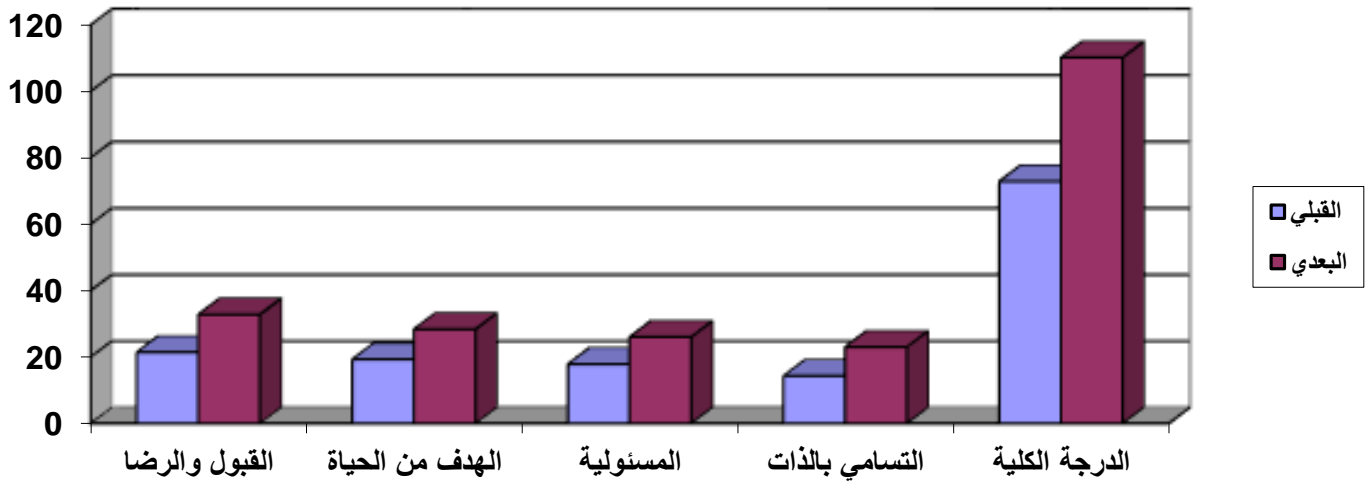

شكل (1) التثثيل البياني لمتوسطي درجات المجموعة في القياسين القبلي والبعدي على مقياس معنى الحياة وأبعاده الفرعية يتضـح مـن شـكل (1) أن التمثبـل البيـاني للدرجات أبعـاد مقيـاس معنى الحيـاة (القبول والرضـا، الهدف من الحياة، المسئولية، التسامي بالذات، الدرجة الكلية) لمعنى الحياة للفتيات المتأخرات في سن الزواج، يظهر فروق بين درجات أفراد مجموعة البحث في القياسين القبلي والبعدي؛ وهذا يؤكد فاعلية البرنامج القائم على فنيات العلاج بالمعنى.

Doi: 10.12816/0041722 
• الفرض الثاني: ينص على أنسه " لا توجد فروق ذات دلالـة إحصائية بين متوسط رتب درجات معنى الحياة في القياس البعدي والقياس التتبعي". ولاختبار صحة هذا الفرض قام الباحثان بحسـاب متوسطي درجـات الفتيـات المعلمـات المتـأخرات في سـن الزواج باسـتخدام أسـلوب إحصـائي بـارامتري (اختبار ت t- test) للأزواج المرنبطة، وذللك لحساب الفروق بين متوسطي درجات مجموعة البحث في القياسين البعدي والتتبعي على مقياس معنى الحياة

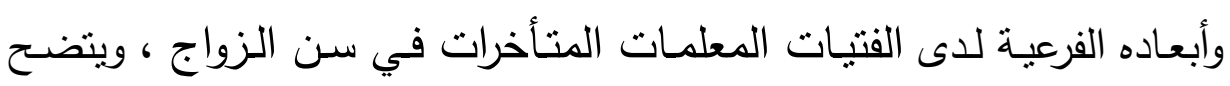

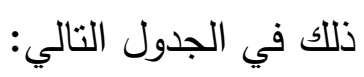

جدول (r) فروق متوسطي درجات مجموعة البحث في القياسين البعدي والتتبعي على مقياس معنى الحياة وأبعاده الفرعية (ن = \& 1 )

\begin{tabular}{|c|c|c|c|c|c|c|}
\hline مستوى & "تيمة & درجة حرية & الانعراف & المتوسط & القياس & مغنى \\
\hline \multirow[b]{2}{*}{ غير دالة } & \multirow[b]{2}{*}{ •, VVY } & \multirow[b]{2}{*}{ ir } & T, TIYTs & Tr,YAOV & البعدي & \multirow{2}{*}{ والزضا } \\
\hline & & & $r, T, 0 \leqslant V$ & $r \mu, \cdot v 1 \leq$ & التتبعي & \\
\hline \multirow{2}{*}{ غير دالة } & \multirow{2}{*}{ 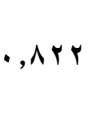 } & \multirow{2}{*}{ ir } & $r, 04 . Y 4$ & 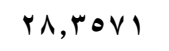 & البعدي & \multirow{2}{*}{ الهنف } \\
\hline & & & r,OQYTI & 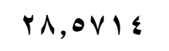 & التتبعي & \\
\hline \multirow{2}{*}{ غير دالة } & \multirow{2}{*}{ 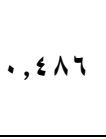 } & \multirow{2}{*}{ ir } & $1, T$ TVYr & $r q, \ldots$ & البعدي & \multirow{2}{*}{ المسئولية } \\
\hline & & & 1,07191 & ro, AOVI & التتبعي & \\
\hline \multirow{2}{*}{ غير دالة } & \multirow{2}{*}{.,Or. } & \multirow{2}{*}{ ir } & 1,97117 & $r r, \ldots$ & البعدي & \multirow{2}{*}{ بالذات } \\
\hline & & & 1,Arrvo & $r r, \wedge \circ v 1$ & التتبعي & \\
\hline \multirow{2}{*}{ غير دالة } & \multirow{2}{*}{ 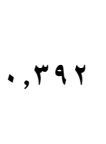 } & \multirow{2}{*}{ it } & V, rTVAA & $11 ., 1 \leqslant$ ห & البعدي & \multirow{2}{*}{ الالكية } \\
\hline & & & $q, V \cdot q \leqslant r$ & $11, r, r \circ v$ & التتبعي & \\
\hline
\end{tabular}

يتضـح مـن الجدول (r) أن قيمـة (ت) المحسوبة لأبعـاد مقيـاس معنى الحيـاة

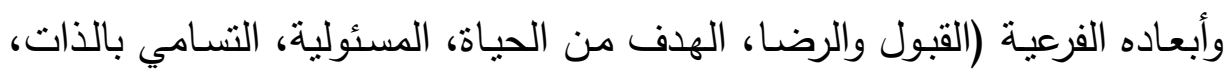

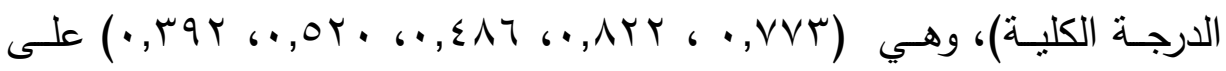


فعالية برنامج إرشادى قائم على العلاج بالمغنى لخفض الاكتئاب الناتج عن تأخر سن الزواج لدى المعلمات

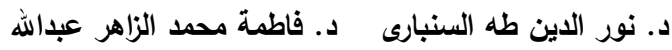

الترتيب، وهي قيم أصغر من القيمة الحدية (91, 1 ) مما يشير إلى وجود فروق

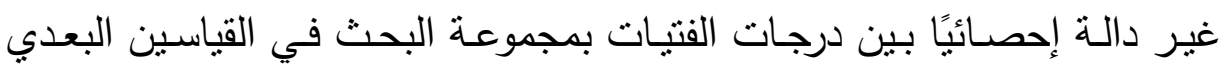
والتتبعي بعد تطبيق البرنامج بفترة زمنية شهرين تقريباً علي مقياس معنى الحياة، لئه وبذلك يتم قبول الفرض الموجه. كما يوضح الثكل (r) الآتي التمثيل البياني لقيم منوسطي درجات معنى الحياة (القبول والرضا، الهدف من الحياة، المسئولية، التسامي بالذات ، الدرجة الكلية) لمجموعة البحث في القياسين البعدي والتتبعي.
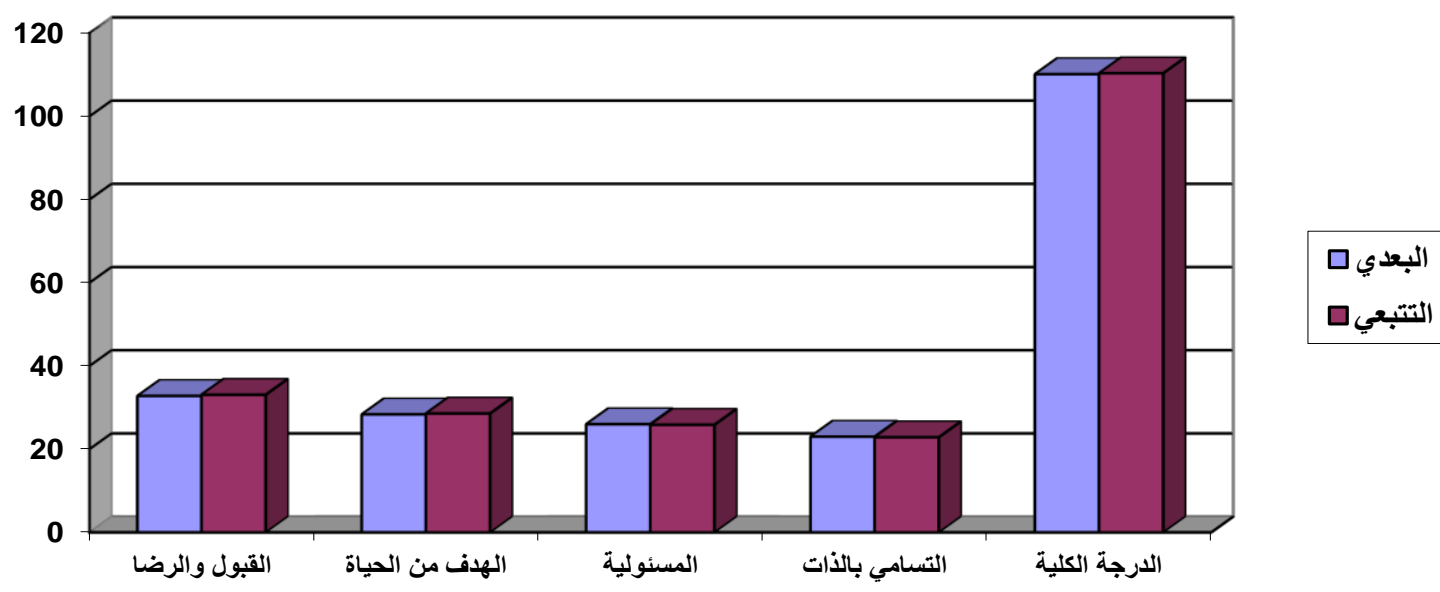

شكل (r) التمثيل البياني لمتوسطي درجات مجموعة البحث في القياسين البعدي والتتبعي

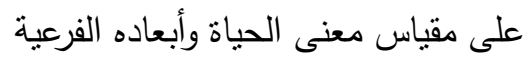

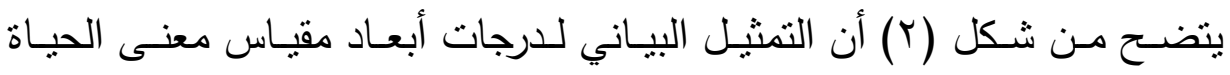
(القبول والرضـا، الهدف من الحياة، المسئولية، التسامي بالذات، الدرجة الكلية) لأفراد مجموعة البحث في القياسين البعدي والتتبعي لا يظهر فروق بين درجاتهن

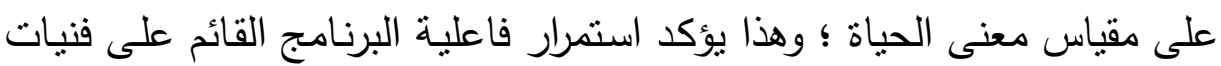

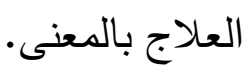




\section{تفسبر نتائج الفرض الأول والثاني:}

تتفق هذه النتائج السابق عرضها مـع نتائج بعض الدراسات السابقة في تحسين

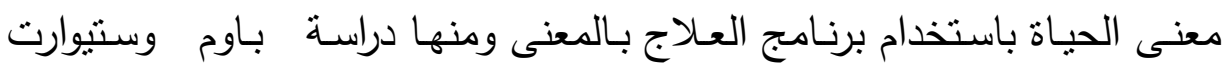
Baum, \& Stewart, (1990) في الحباة، ووجدا أن بعض الأحداث قد ارتبطت بالثخص نفسه كالخبرات التي هني

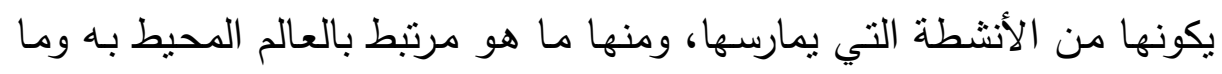

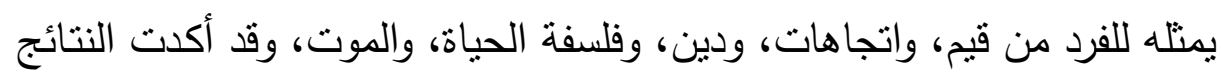

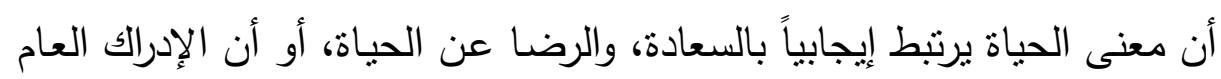

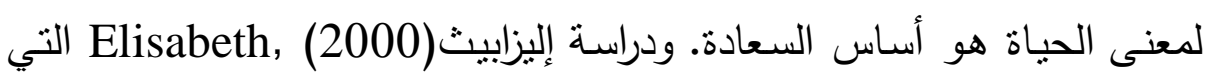

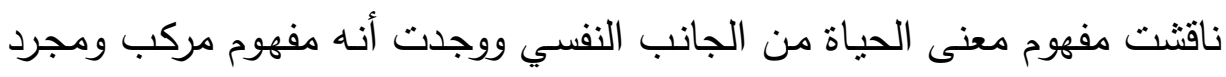
وفي بعض الأحيان غامض، وقد أوضحت أن المعنى في الحياة ربما يرتبط

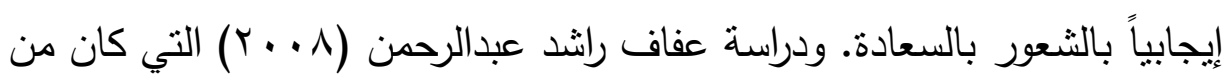

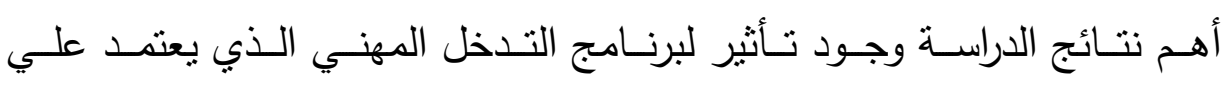

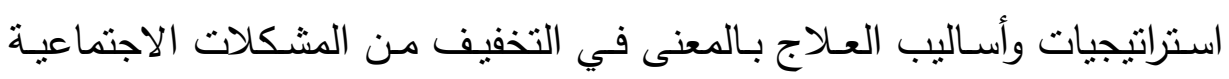
النفسية للفتيات المتأخرات في الزواج.

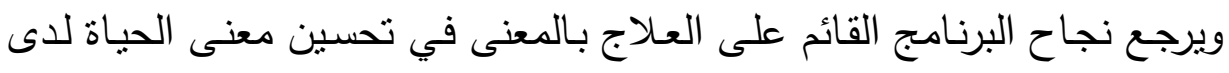

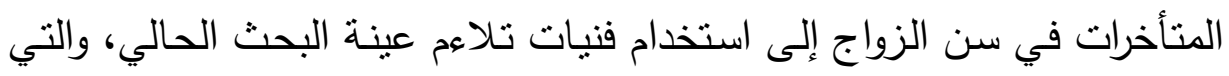

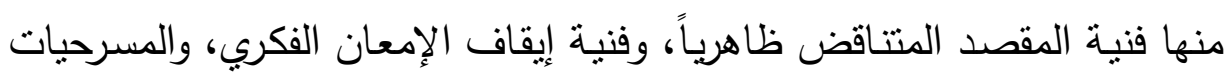

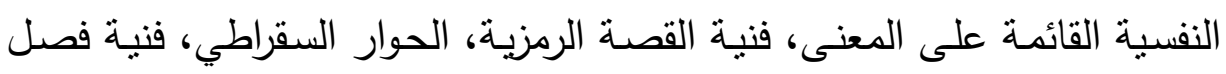
الذات، فنية إعادة البناء الموقفي، تعديل الاتجاهات. ويمكن تفسير ذلك في أن تعرض مجموعة البحث للبرنامج القائم على العـلاج

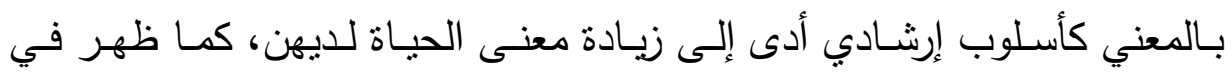

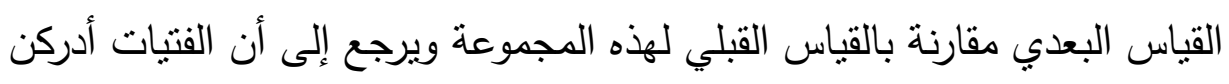

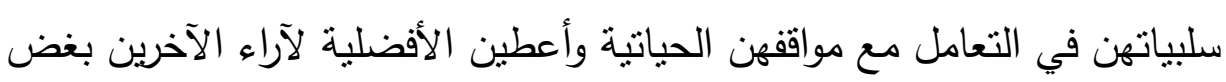


النظر عن رغبـاتهن، أسلمن زمـام أمورهن للآخرين، كما أعدن تقيهم حياتهن السابقة للوقوف على نقاط الضعف والاستفادة من الخبرات السابقة.

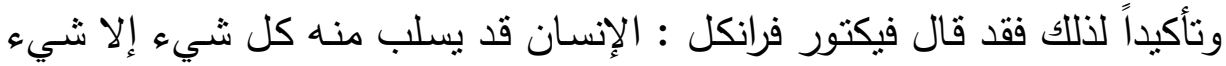
واحداً؛ ألا وهو اختياره للموقف الذى سيتخذه في ظل أية مجموعة من الظروف؛

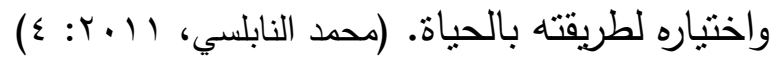
في حين كان يهرف هذا البرنامج من معرفة معنى الحياة والقيم الموجودة في هذه

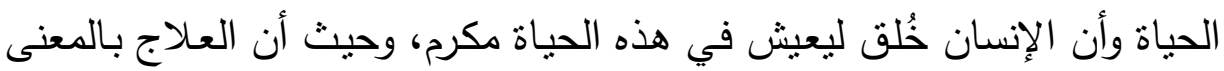
القائم على نظرية ومبادئ العلاج بالمعني لفرانكل ويركز على مساعدة العميل في لهي اكتشاف إحساس جديد بالمعنى من خلال تحليل خبرات حياته للوصول لمصادر

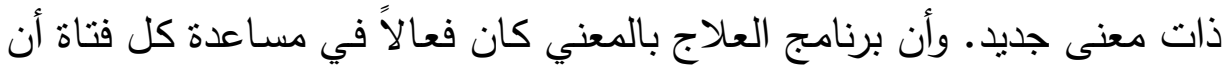
تحدد وتكتشف الأهداف التي تسعى لتحقيقها والتي تتسعرها بالقيمة في الحياة

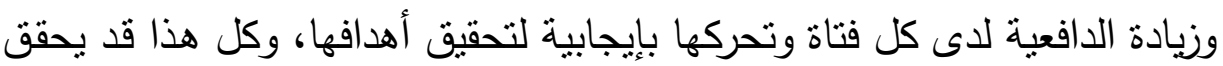

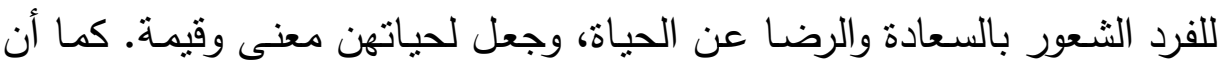

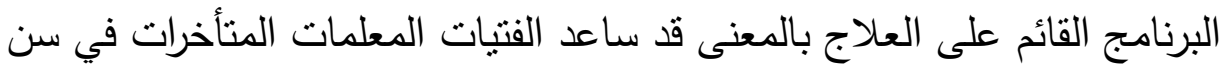
الزواج على أن يصـبحوا متقتحين على الحيـاة ومـزودين بـوعي جديـ بـذاتهن

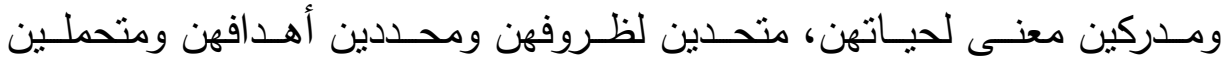
لمسئولياتهن، وبذللك ليصبحوا مؤهلين للنجاح في الحياة.

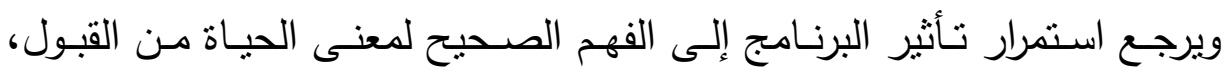

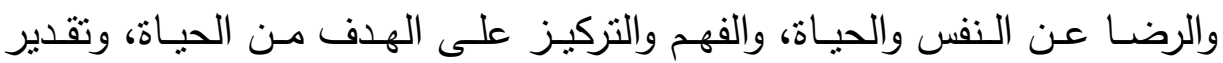
المسئولية، وفي ظل كل هذا يأني التسـامي بالذات، ومـن خـلال نظـرة الأملـ والتفاؤل والإرادة القوية وتحديد الهدف والعمل بكفاءة والإخلاص في العمل. كما وليا ركز البرنامج على تقييم الفتاة لذاتها وضرورة إحداث تغيير ايجابي في اتجاه الفتاة نحو نفسها وظروفها التي لا بمكن تغييرهـا، وذلك من خـال فنيـة تعديل

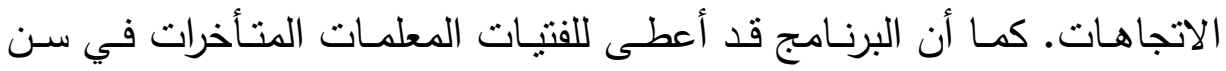


الزواج قدر من الوعي بأنفسهن وبقدراتهن وطاقاتهن ووجههن إلى كيفية استتمار

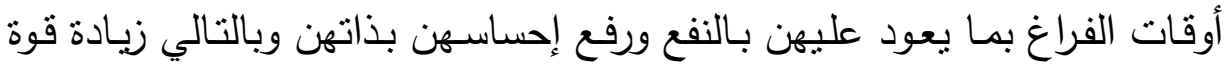

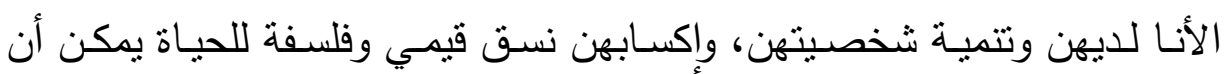
تساعدهن على التعامل مع ضغوط الحياة بكفاءة وإخلاص. • الفرض الثالث: ينص على أنه "توجد فروق ذات دلالة إحصائية بين متوسط بله رتب درجات الاكتئاب في القياسين القبلي والبعدي لصالح القياس البعدي". ولاختبار صحة هذا الفرض حسب متوسطي درجات الفتيات باستخدام أسلوب إحصائي بارامتري (اختبار ت t-test) للأزواج المرتبطة، وذللك لحساب الفروق هُون بين منوسطي درجات مجموعة البحث في القياسين القبلي والبعدي على مقياس

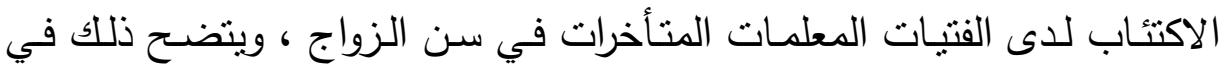

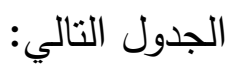

جدول ( ) اتجاه فروق متوسطي درجات مجموعة البحث في القياسين القبلي

\begin{tabular}{|c|c|c|c|c|c|c|}
\hline \multicolumn{7}{|c|}{ والبعدي على مقياس الاكتئاب (ن= \& 1) } \\
\hline مستوى الدلاد & ق ق قيمة "ت" & درجة حرية & الانحراف المعياري & 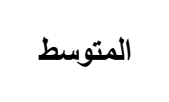 & القياس & المقياس \\
\hline \multirow{2}{*}{., .1} & \multirow{2}{*}{$r \wedge, 09 \leqslant$} & \multirow{2}{*}{ Ir } & $\varepsilon, 7 \leqslant \uparrow q$ & $\|1, r\| \leqslant$ & القبلي & \multirow{2}{*}{ الاكتئاب } \\
\hline & & & $0,1.0 \leq 1$ & $\wedge \cdot, r \wedge \odot \vee$ & 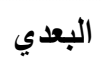 & \\
\hline
\end{tabular}

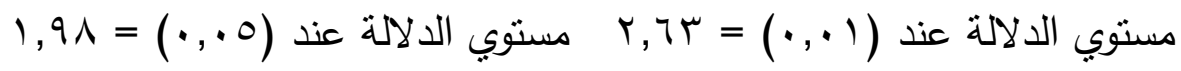

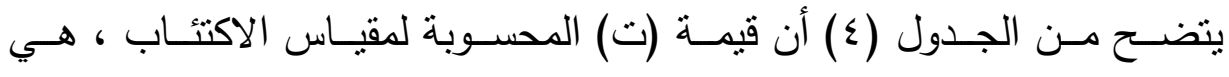

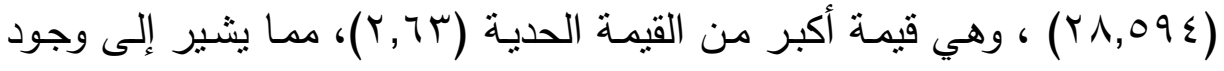
فروق دالة إحصائيًا عند مستوي دلالة (1 ب. , •) بين درجات أفراد مجموعة البحث

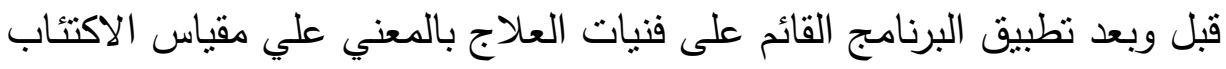
لصالح القياس البعدي، وبذلك يتم قبول الفرض الموجه.

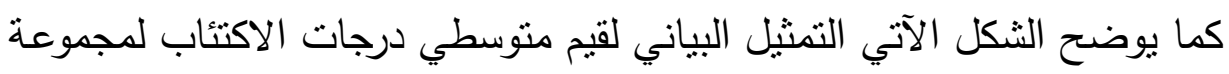
البحث في القياسين القبلي والبعدي لصالح القياس البعدي. 


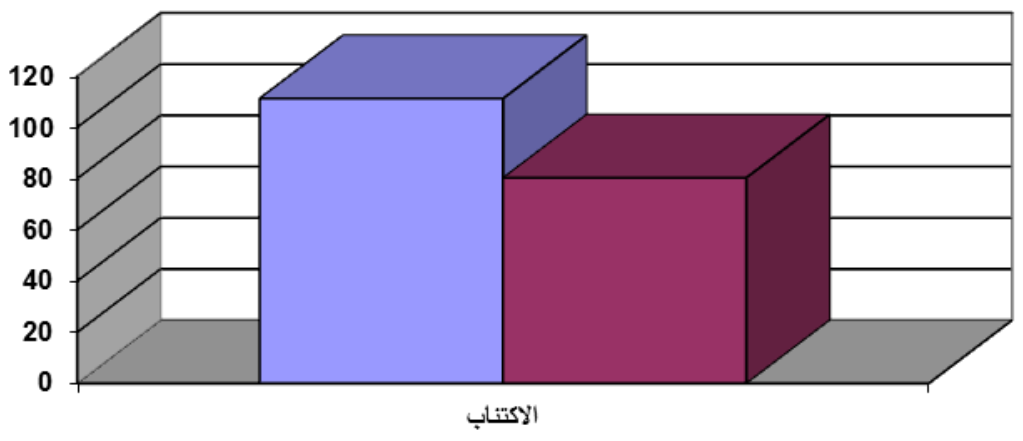

شكل (r) التمثيل البياني لمتوسطي درجات المجموعة في القياسين القبلي والبعدي على مقياس الاكتئاب

يتضح من شكل (r) أن التمثيل البياني لدرجات أبعاد مقياس الاكنئاب للفتيات المتأخرات في سن الزواج، بظهر فروق بين درجات أفراد مجموعة البحث في القياسين القبلي والبعدي؛ وهذا يؤكد فاعليـة البرنـامج القائم على فنيات العـلاج بالمعنى. • الفـرض الرابـع: ينص على أنسه "لا توجـ فروق ذات دلالـة إحصـائية بـين متوسط رتب درجات الاكتئاب في القياس البعدي والقياس التتبعي". ولاختبـار صـحة هـذا الفـرض قـام الباحثـان بحسـاب متوسـي درجـات الفتيـات المعلمات المتأخرات في سن الزواج باستخدام أسلوب إحصـائي بارامنري (اختبار ت t- test) لـلأزواج المرتبطة، وذلك لحساب الفروق بين متوسطي درجات مجموعة البحث في القياسين البعدي والتتبعي على مقياس الاكتئاب لدى الفتيات المعلمات المنأخرات في سن الزواج ، ويتضح ذللك في الجدول التالي: 


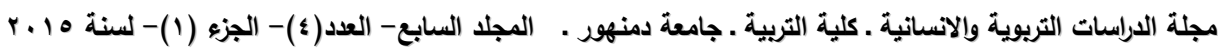

جدول (•) فروق متوسطي درجـات مجموعـة البحث في القياسـين البعدي

\begin{tabular}{|c|c|c|c|c|c|c|}
\hline & & & ( $1 \leqslant=0$ & ياس الاكتئ & على & وإلتب \\
\hline اللالاتة & "تيمة & درجة حرية & الانحراف المعياري & المتوسط & القياس & المقياس \\
\hline \multirow[b]{2}{*}{ غير دالة } & \multirow[b]{2}{*}{., OV9 } & \multirow[b]{2}{*}{ ir } & $0,1.0 \leqslant \wedge$ & $\Lambda ., Y \wedge O V$ & البعدي & \multirow[b]{2}{*}{ الاكتئاب } \\
\hline & & & $\varepsilon, \Gamma ৭ ৭ \wedge \wedge$ & $\Lambda_{\cdot}, \mathrm{VA} \odot \mathrm{V}$ & التتع & \\
\hline
\end{tabular}

يتضـح من الجدول (0) أن قيمة (ت) المحسوبة لأبعاد مقياس الاكتئاب ، وهي

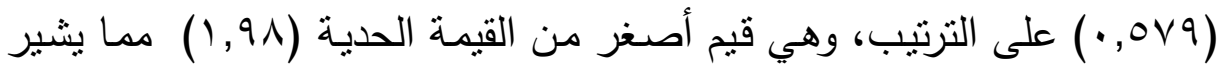
إلى وجود فروق غير دالة إحصائيًا بين درجات الفتيات بمجموعة البحث في لئي

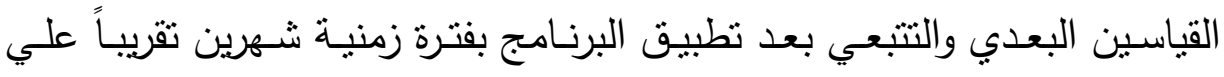
مقياس الاكتئاب ، وبذللك يتم قبول الفرض الموجه.

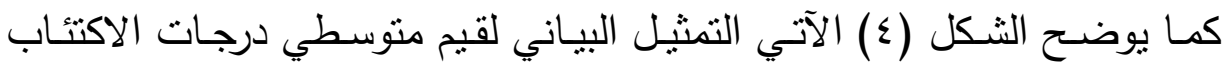
لمجموعة البحث في القياسين البعدي والتنبعي.

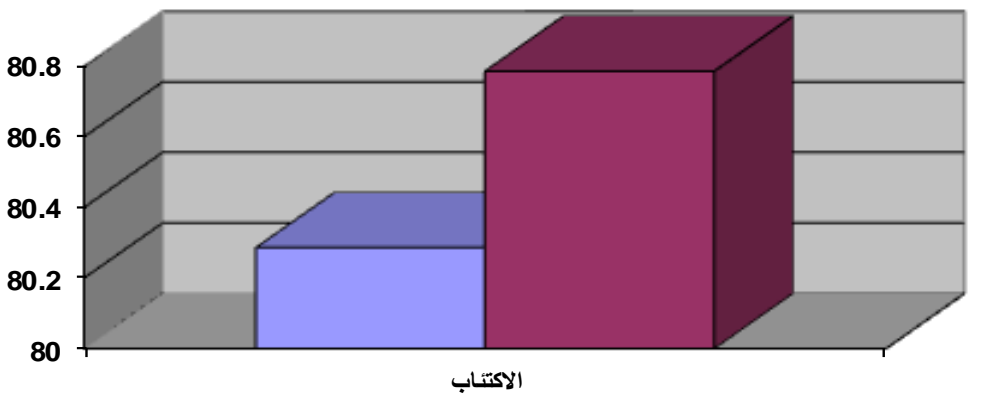

|البعدي ه

شكل (ع) التشثيل البياني لمنوسطي درجات مجموعة البحث في القياسين البعدي والتتبعي على مقياس الاكتئاب يتضـح من شكل (ع) أن التمثيل البياني لدرجات أبعاد مقياس الاكتئاب لأفراد مجموعة البحث في القياسين البعدي والتتبعي لا يظهر فروق بين درجاتهن على 
مقياس الاكتئاب ؛ وهذا يؤكد استمرار فاعلية البرنامج القائم على فنيات العلاج

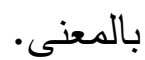

\section{• تفسير نتائج الفرض الثالث واليرايع:}

تتفق النتائج السابقة مع نتائج بعض الدراسات السابقة ومنها دراسة نسرين على التى

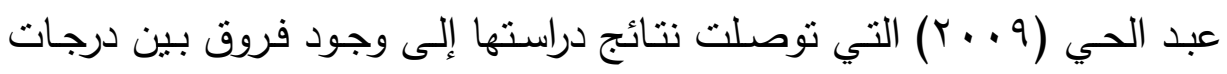

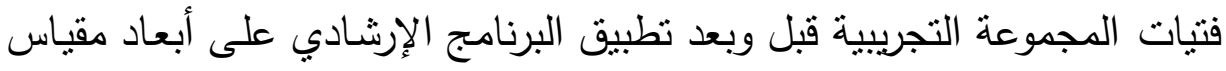

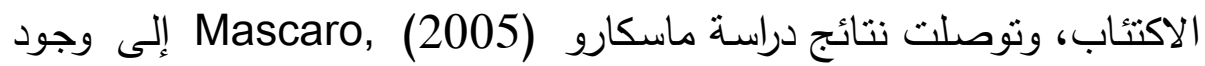
علاقة ارتباطية سالبة بين الإحساس بالمعنى الوجودي وبين الإصابة بالاكتئاب، ووجود علاقة إيجابية ذات دلالة إحصائية بين الإحساس بالمعنى الوجودي، وبين

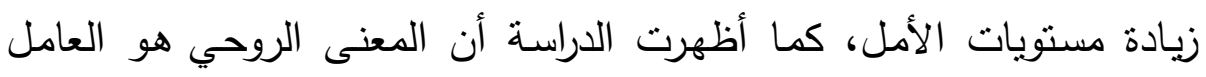

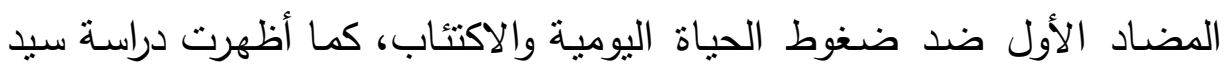

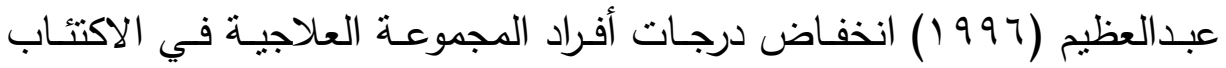
التقـاعلي، ممـا يشـير إلي فعالية البرنـامج العلاجي للتفجر الداخلي في عـلاج الاكتئاب التفاعلي، ودراسة إليزابيث(Elisabeth, (2000) التي أوضحت أن

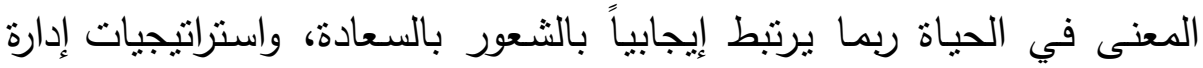

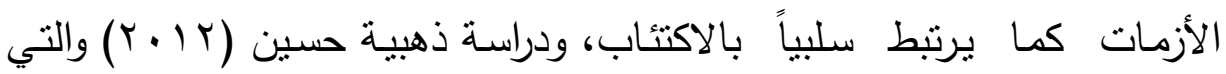
توصلت إلى وجود ارتباط سالب ودال بين درجة قلق المستقبل ومستوى التوافق

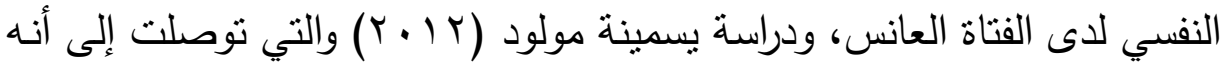

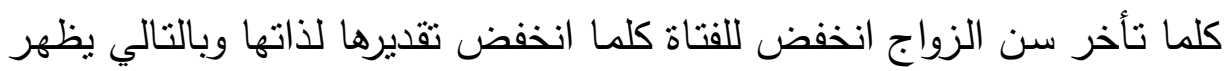

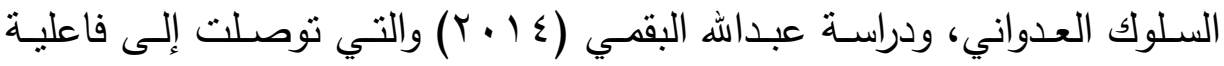
برنـامج العلاج بالمعنى في تخفيض حده الاكتئاب. وعليه ومن خـال استخدام

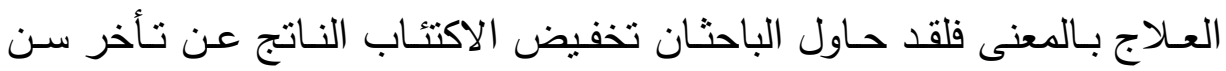
الزواج وما يرتبط بـه من متلازمات مثل قلق المستقبل والسلوك العدواني، كذللك 
عمل الباحثان على أن تكون لدى الفتاة نظرة موضوعية واقعية عقلانية والبعد

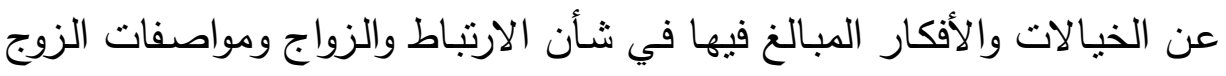

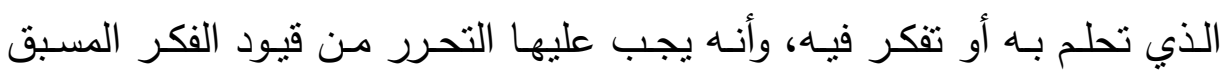

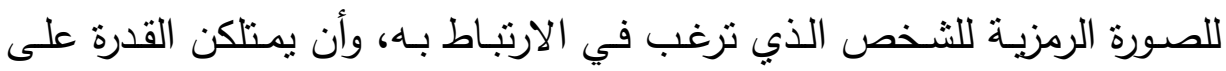
التقييم الفعلي للبدائل المطروحة، وأن لكل فرد أياً ما كان جوانب إيجابية وسلبية،

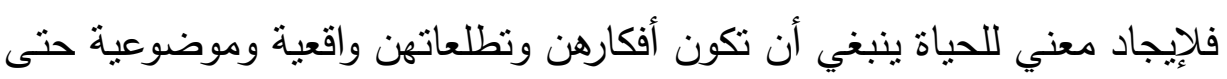
يمكن تحقبقها.

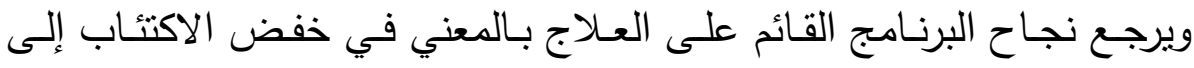
تفاعل الفتيات المعلمات المتأخرات في سن الزواج في جلسات البرنامج وحرصهن

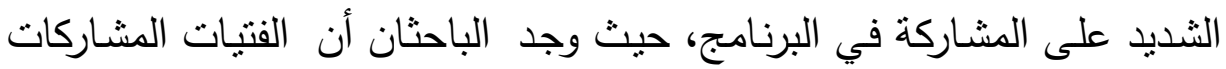
أثناء الجلسات كان لايهن الاهتمام والتركيز على متابعة جميع الجلسات

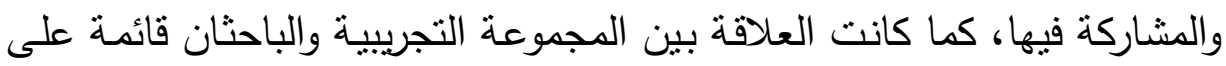

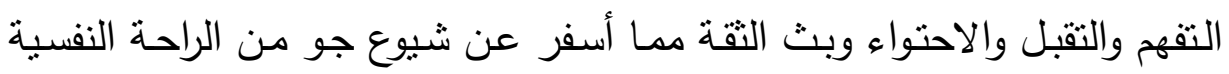

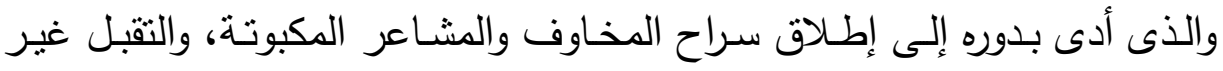
المشروط للششاركات وأفكارهن الذى كان له الأثر الكبير في نجاح الجلسات واستمرارها بفعالية حتى النهاية، وكان للفنيات المستخدمة والواجبات المنزلية التي تم مراجعتها علنياً أمام المجموعة قبل بداية الجلسات الأثر الواضتح في تعميق وكان

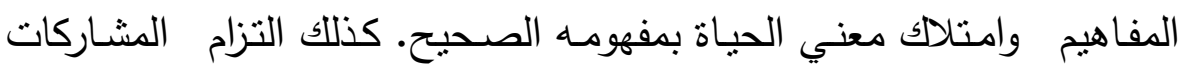
وحضورهن لجميع الجلسات، وتطبيقهن للمهارات التي اكتسبوها خلال الجلسات في حياتهن اليومية حيث اتضـح ذللك من خلال التقييمات اليومية والختامية للجلسات، كما أن قابلية المشاركات ودافعيتهن للاستفادة كان له دور كبير في لهي

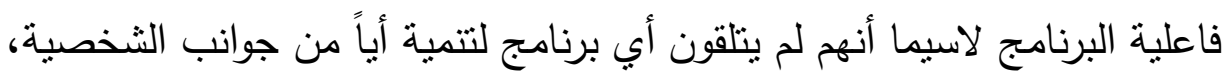

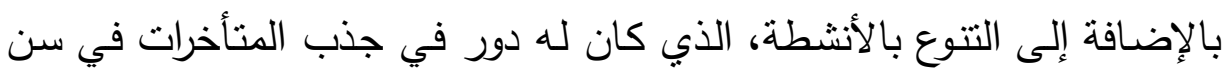
الزواج للمواظبة على حضور الجلسات. 
ويُرجع الباحثان قدرة البرنامج القائم على العلاج بالمعنى في مساعدة المعلمات

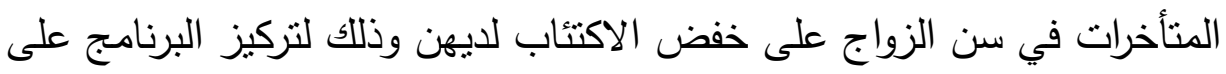

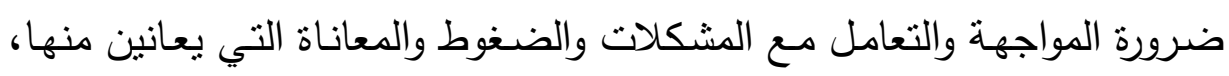

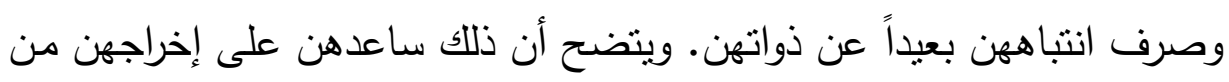

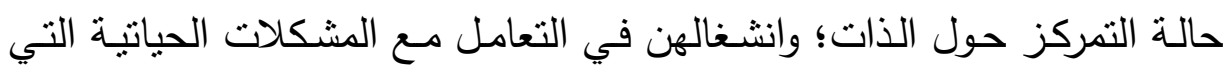
تواجهرن وتسبب إحساسهن بالاكتئاب.

كما أنه بعد تعرض الفتاة المتأخرة في سن الزواج للبرنامج أصبح مفهوم معني

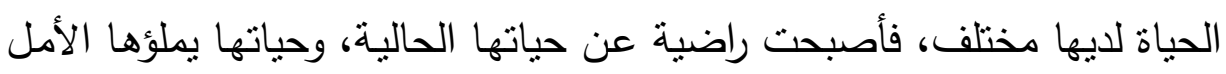

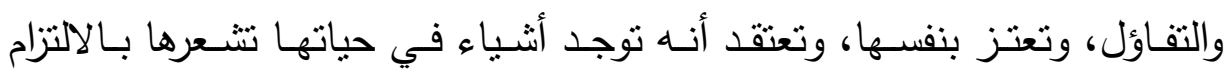
الحقيقي نحوها، ونتارك في أب عمل تطوعي يفيد الآخرين، والبعض منهن فكرن

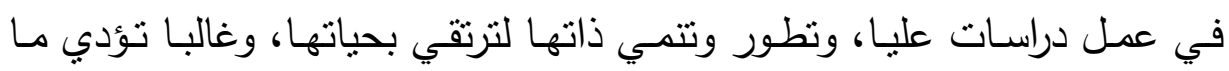

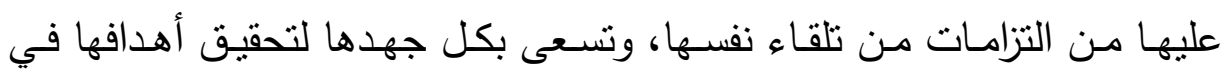

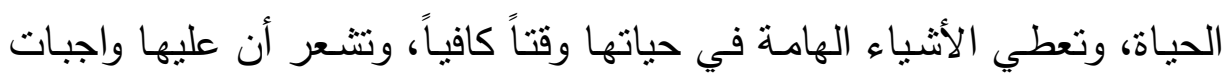

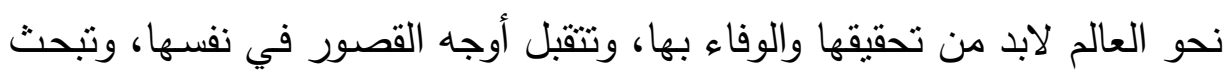
عن أفضل الأساليب لاستغلال قدراتها ومواهبها، وتبذل قصارى جهدها فيما تقوم

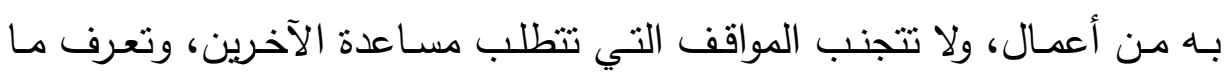

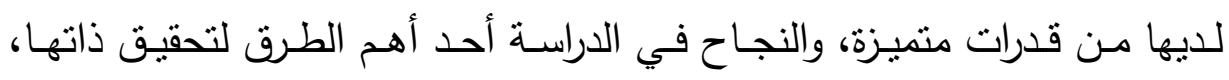
وتحاول تعلم مهارات جديدة نساعدها في حياتها العملية. ويرجـع استمرار تأثثير البرنـامج إلى الفهم الصـيح لمعنى الحبـاة من القبول

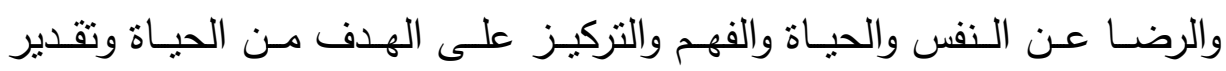

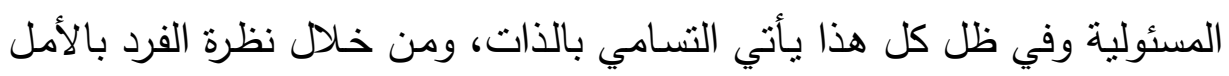

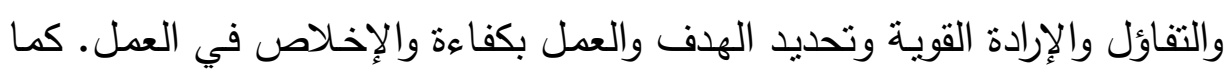

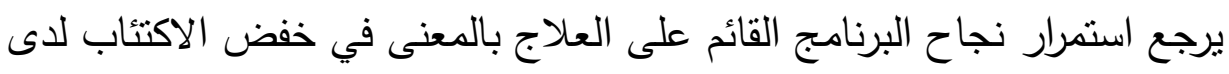




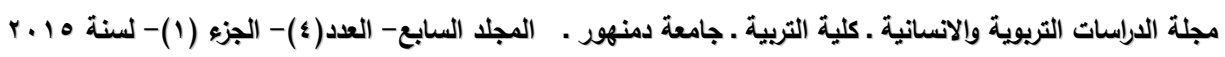

المتأخرات في سن الزواج إلى استخدم فنيات تلاعم عينة البحث الحالي، والتي

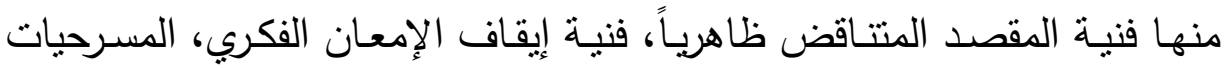

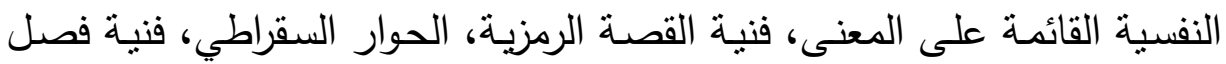
الذات، فنية إعادة البناء الموقفي، تعديل الاتجاهات. 


\section{التوصيات والبحوث المقترحة:}

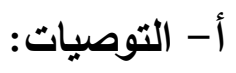

في ضوء إجراءات البحث الحالي، وما نوصل إليه الباحثنان من نتائج، فإنه يقترح بعض التوصيات التربوية: م إجراء المزيد من البحوث التي تتتاول الجوانب السيكولوجية عند المتأخرات في سن الزواج بهدف معرفة نواحي القصور في هذه الجوانب والعمل على تطويرها

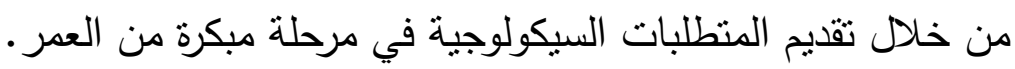
م إجراء المزيد من البحوث التي تنتاول موضوع معنى الحياة والاكتئاب. O تبني نتائج هذا البحث والعمل على بناء برامج تربوية نفسية.

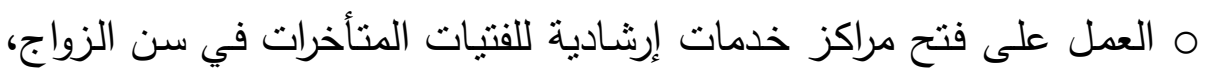
ويمكن تفعيل ذللك من خلال تعميم فكرة برامج التأهيل النفسي للفتيات.

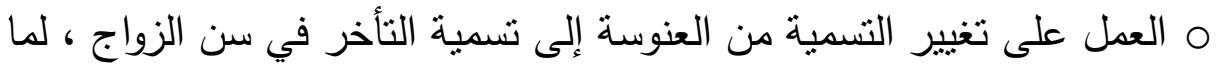
يعود لهذه التسمية من أثز نفسي على الفتاة وتذكيرها بمشكلتها بشكل دائم وقاسي. م ضرورة الاهتمام بالجانب النفسي لدى الفتيات المعلمات المتأخرات في سن

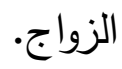




\section{-}

م فعاليـة برنـامج قائم على العـلاج بـالمعني في تحسين السلوك التوافقي لدى المتأخرات في سن الزواج.

م العلاقة بين معني الحياة والاضطرابات النفسية للفتيات المتأخرات في سن سن الزواج.

م فعالية برنامج قائم على العلاج العقلاني الانفعالي في خفض الاكتئاب للى المتأخرات في سن الزواج.

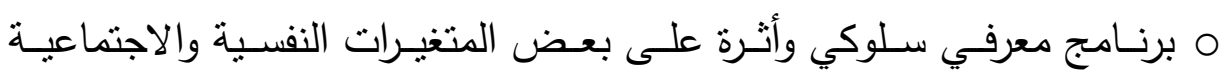
والأسرية لدى المتأخرات في سن الزواج. 
فعالية برنامج إرشادى قائم على العلاج بالمغنى لخفض الاكتئاب الناتج عن تأخر سن الزواج لدى المعلمات

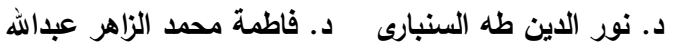




\section{قائمة المراجع}

أولاً: المراجع العربية:

- إبراهيم محمود بدر • (r . . Y). مستوى التوجه نحو المستقبل وعلاقته ببعض

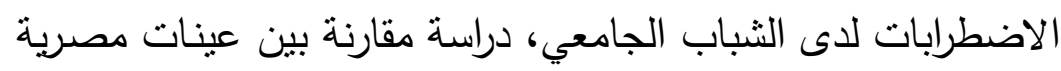

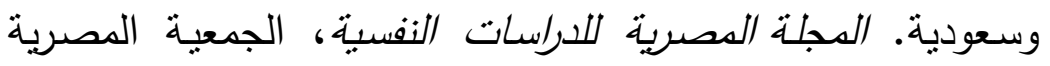

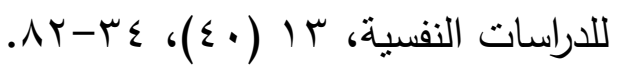

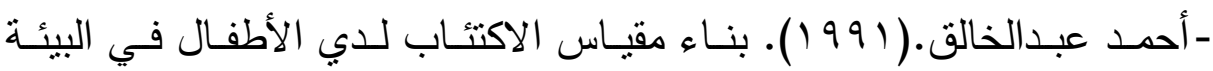

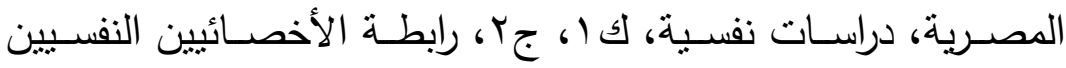

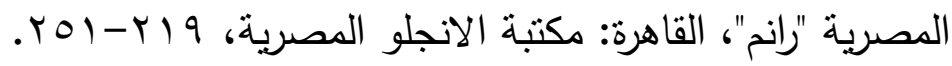

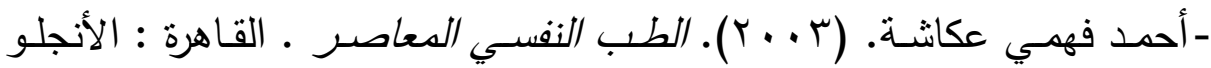
المصرية.

- أحمد محمد عبدالخالق، ومحمد نجيب الصبوة. (997 (1)). الأنشطة والأحداث

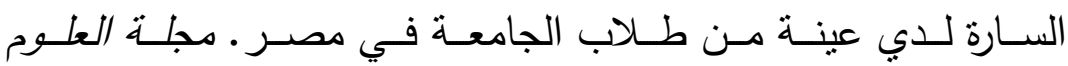

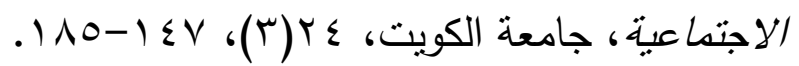

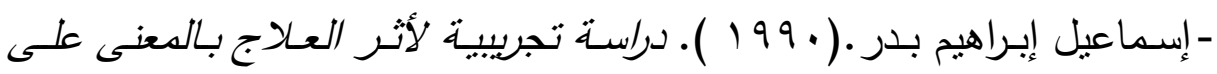

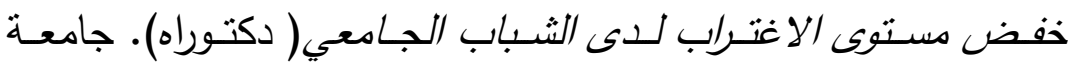

الزقازيق: كلية التربية ببنها.

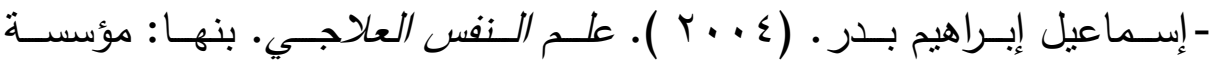

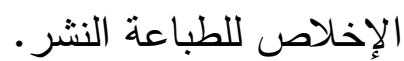

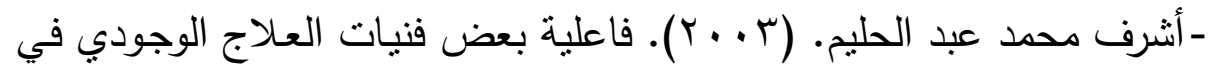

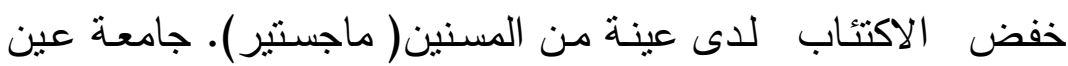
شمس: كلية التربية.

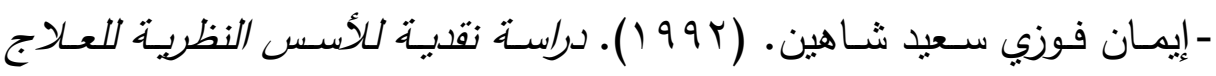
الوجودي( دكتوراه). جامعة عين شمس: كلية التربية. 
-بدر محمد الأنصاري. (99V (19). الاكتئاب والعدوان العراقي : دراسة لمعدلات

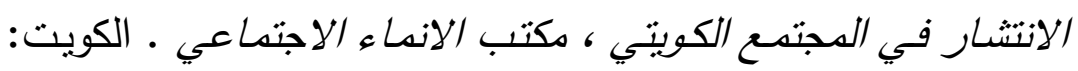
• الديوان الأميري

-ذهبية حسين. (r ( r). قلق المستقبل لدى الفتاة العانس وعلاقته بالتوافق

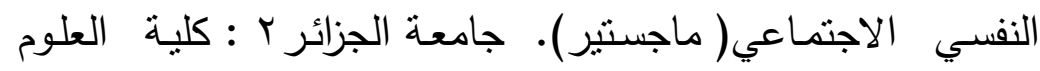
الإنسانية والاجتماعية.

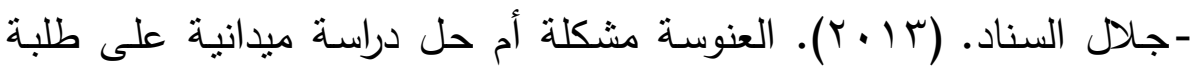

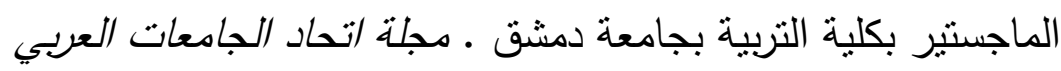

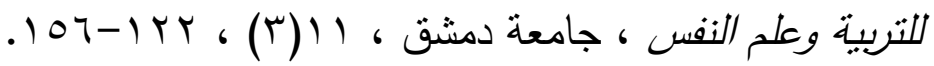
- خيرة بغدادي. (ديسمبر ب | • ب). ظاهرة العنوسة في المجتمع الجزائري وتأنثرها

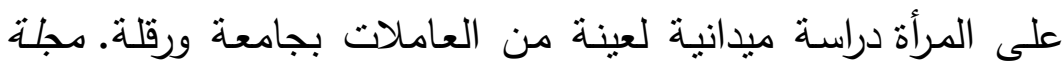

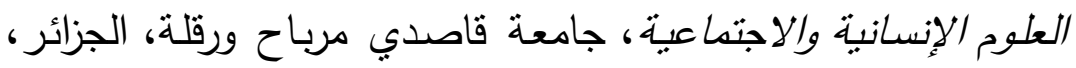
.11

- سيد أحمد البهاص. (أكتوبر 9 . . r). فعالية الإرشاد بالمعنى في خفض قلق العنوسة وتحسين معنى الحياة لدى طالبات الدراسات العليا المتأخرات

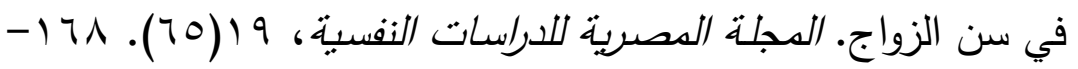
. TI

- سيد عبد العظيم محمد عبد الوهاب. (1997 ). أثر كل من العلاج بالدعني

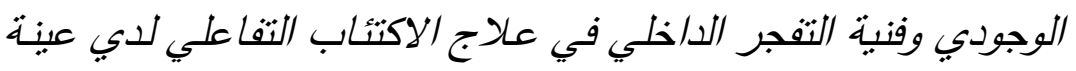
من طلبة الجامعة ( دكتوراه). جامعة المنيا: كلية التربية.

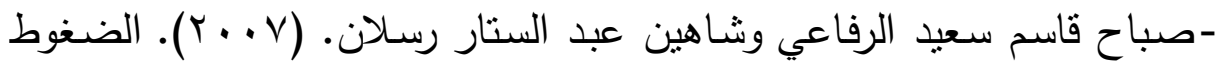
النفسية لدى الفتيات المتأخرات زواجياً في البيئة السعودية و البيئة

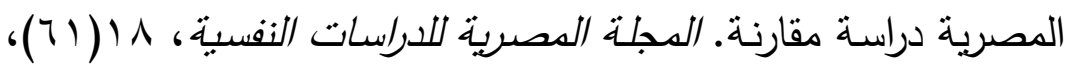
. $17 r-1 \%$. 


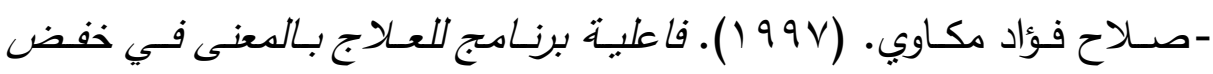

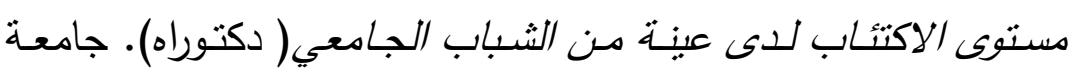

عين شمس: كلية التربية.

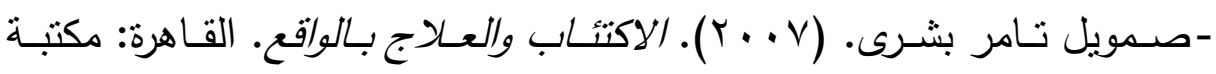
الأنجلو المصرية.

- عبد الرحمن سيد سليمان، إيمان فوزي. (نوفمبر 999 ()). معنى الحياة وعلاقته

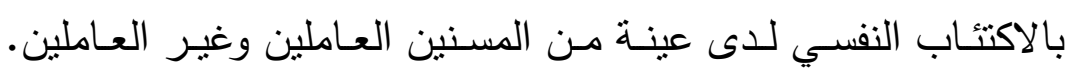

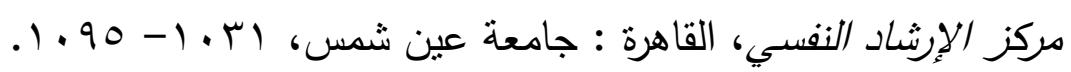

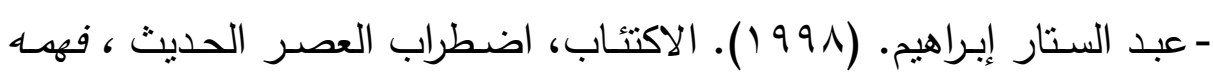
وأساليب علاجه ـ الكويت: عالم المعرفة.

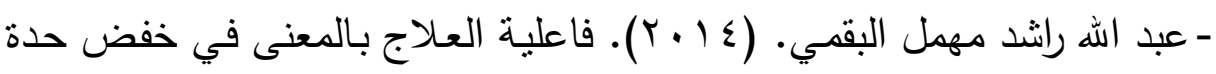

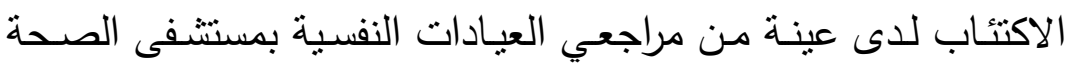
النفسية بالطائف، دكتوراه، كلية التربية، جامعة عين شمس.

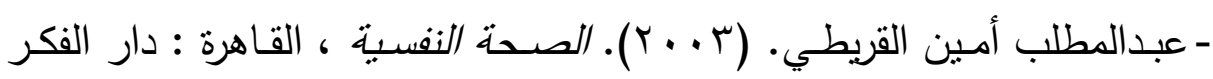
العربي.

- عبده كامل الطائفي. (9 . . ب). المشكلات الأسرية للفتاة العانس في المجتمع

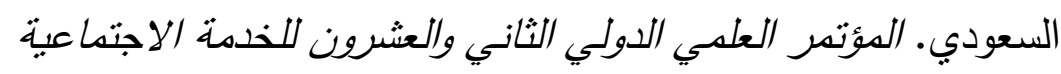

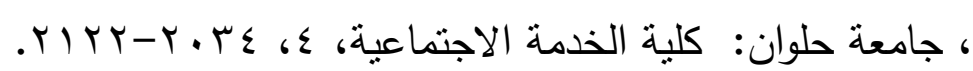

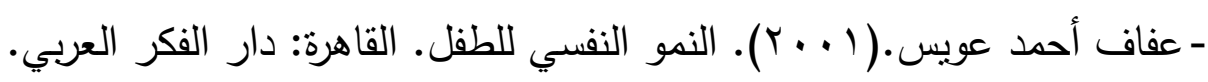

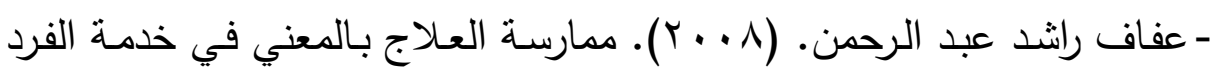

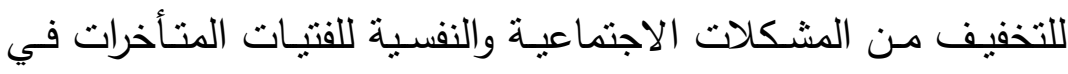

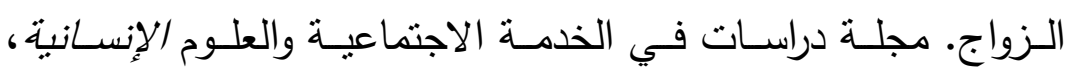

$$
\text { .VVO-VOE (T) Yr }
$$


فعالية برنامج إرشادى قائم على العلاج بالمغنى لخفض الاكتئاب الناتج عن تأخر سن الزواج لدى المعلمات

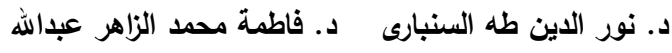

- غريب عبدالفتاح غريب .(Y......). مقياس بيك الثاني للاكتثاب. القاهرة: مكتبة الانجلو الدصرية.

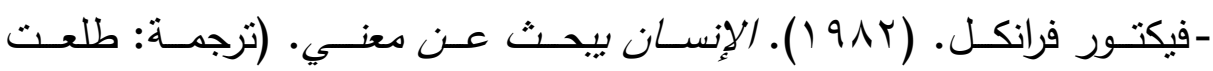
منصور)، القاهرة، مكتبة الأنجلو المصرية.

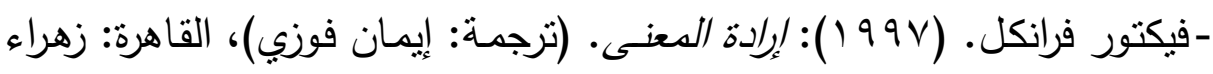

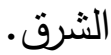

-لطفي الثربيني. (ץ . - ץ). معجم مصطلحات الطب النفسي. الكويت: مركز

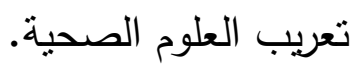

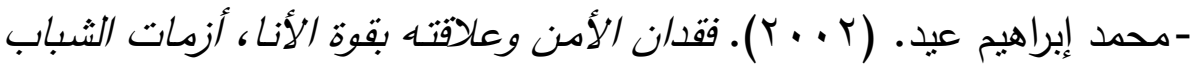
النفسية. القاهرة: دار الزهراء.

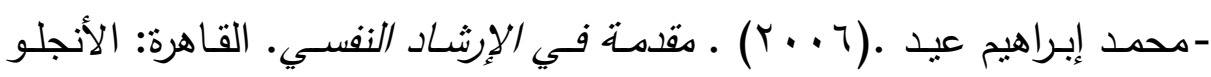

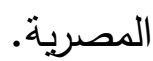

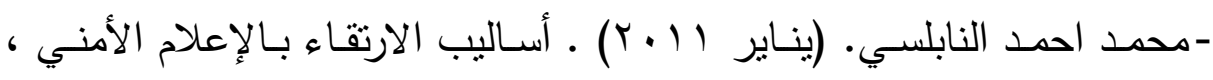
مجلة الثقافة النفسية المتخصصة ، طرابلس، بrايل (10).

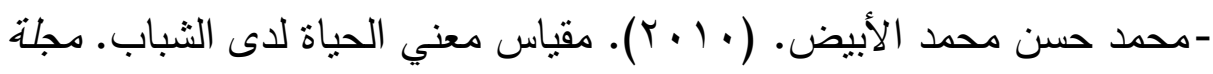

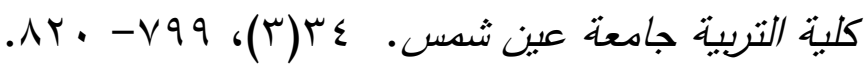

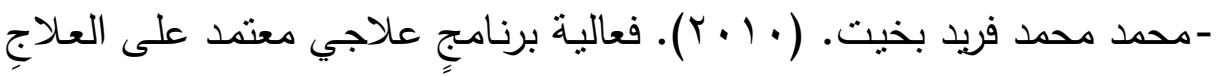

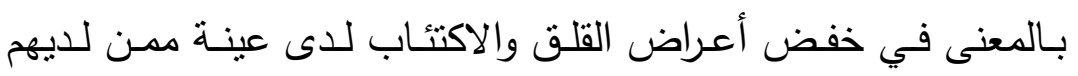
المرضي النفسيين( دكتوراه). جامعة الزقازيق: كلية الآداب.

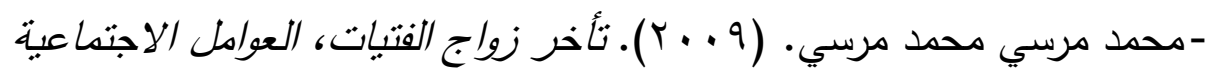
والاقتصادية. الرياض: جامعة نايف العربية للعلوم الأمنية. - منة اله محمد حسن ، وعمرو السيد عبداله، ومصطفى أحمد محمد. (9 . . ب). حل مشكلة العنوسة بين الثباب. بحث مقدم لمسابقة البحوث العلمية

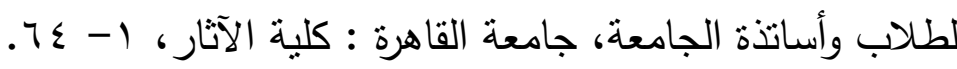
Doi: 10.12816/0041722 


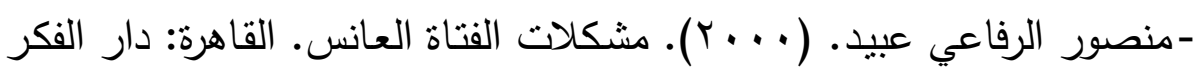

$$
\text { العربي. }
$$

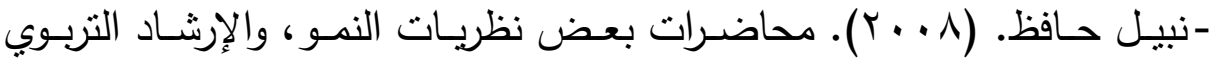

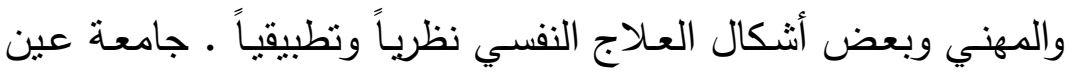
شمس: كلية التربية.

- نسرين على عبد الحي النعناعي. (9 . . ب). فعالية برنـامج إرشـادي لتخفيف حدة بعض المشكلات النفسية لاى عينة من العناس المتأخرة زواجياً (ماجستير). جامعة عين شمس: كلية التربية.

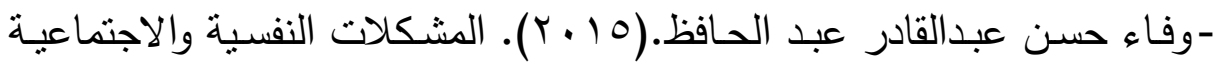
للدي عينة من العانسات والمطلقات باستخدام منهج المقابلة المتعققة وتحليل المضمون( ماجستير) · جامعة المنيا: كلية الآداب.

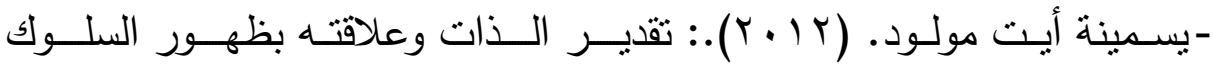

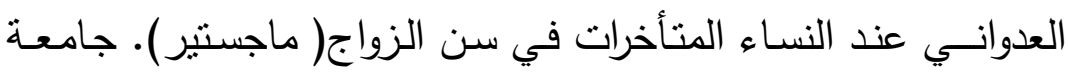
مولود معمري - تيزي وزو: كلية العلوم الإنسانية والاجتماعية.

ثانياً: المرجع الاجنية: مولئ

- Baum, S. K. \& Stewart, R.B. (1990). Sources of Meaning Through The Lifespan. Psychological Reports. 67, 14-17.

- Earnshaw E. L. (2000). Religious orientation and meaning in life: An exploratory study (Unpublished manuscript). National Undergraduate Research Clearinghouse, 3. Retrieved from:http\|WWW.Clearinghousemucoid \manuseripts 172.asp.Aug..17

- Elisabeth, A. (2000). On the Psychology of Meaning of Life. Swiss Journal of Psychology,59, 34-48. 
فعالية برنامج إرشادى قائم على العلاج بالمغنى لخفض الاكتئاب الناتج عن تأخر سن الزواج لدى المعلمات

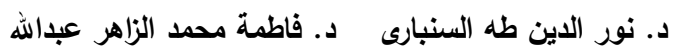

- Frankl, V. (1978). The Unheard Cry for Meaning, London, Hodder and Toughen. New York : Simon and Schuster, Inc.

- Flanagan, John \& Flanagan, Rita. (2004) . Counseling and psychotherapy theories in context and practice: Skills, strategies, and techniques. New Jersey: John Wiley \& Sons, Inc., Hoboken.

- Gladding,S.T (1994). Counseling: AComprehensive $\operatorname{profession}\left(2^{\text {nd }}\right.$ ed.), New York : Macmillan Publishing Company.

- Ivarsson, T., Svalander, P., Litlere, O. (2006). The Children's Depression Inventory (CDI) as measure of depression in Swedish adolescents, A normative study NORD. Journal Psychiatry, 60 (3): 321-325.

- Kim, Mira. (2001). Exploring Sources of Life Meaning Among Koreans, Trinity Western University (Master Thesis). Retrieved from: https://www2.twu.ca/cpsy/theses/kimmira.pdf.

- Colin Leath (1999). The experience of meaning in life from Psychological Perspective. Retrieved from: http://purl.oclc.org/net/cleath/writings/meaning.htm.

- Marshall, M. (2009). Life With Meaning. Canada: Maritime institute of Logotherapy, Halifax, Nova Scotia.

- Mascaro, N. (2005). Existential Meaning's Role in the Enhancement of Hope and Prevention of Depressive Symptoms. Journal of Personality, 73(4),985-1010.

- Olesovsky, Petra. (2003). Meaning in life, and depression: A comparative study of the relation between them across the life span. Dissertation Abstracts 


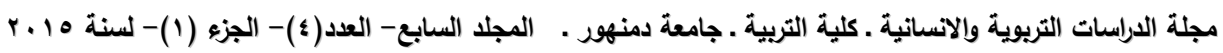

International. Section B: The Sciences and Engineering, 64(2-B), 972.

- Traywick, V. (2007). Depression in the Elderly. University of Arkansas. Retrieved from: www.arfamilies.org/health_nutrition/aging/depressio $\underline{\text { n.pdf. }}$ 
فعالية برنامج إرشادى قائم على العلاج بالمغنى لخفض الاكتئاب الناتج عن تأخر سن الزواج لدى المعلمات

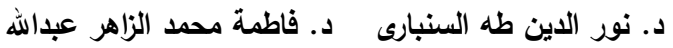

